\author{
UNIVERSIDADE DE BRASÍLIA \\ Instituto de Psicologia \\ Departamento de Psicologia Clínica e Cultura \\ Programa de Pós-graduação em Psicologia Clínica e Cultura
}

\title{
A associação livre em Freud: fundamento do tratamento psicanalítico
}

LUCIANO ANTUNES FIGUEIREDO SOUSA

Brasília, 2018 


\author{
UNIVERSIDADE DE BRASÍLIA \\ Instituto de Psicologia \\ Departamento de Psicologia Clínica e Cultura \\ Programa de Pós-graduação em Psicologia Clínica e Cultura
}

\title{
A associação livre em Freud: fundamento do tratamento psicanalítico
}

LUCIANO ANTUNES FIGUEIREDO SOUSA

Dissertação submetida ao Programa de Pós-graduação em Psicologia Clínica e Cultura do Instituto de Psicologia da Universidade de Brasília, como requisito parcial à obtenção do título de Mestre em Psicologia Clínica e Cultura.

Orientador: Professor Dr. Luiz Augusto Monnerat Celes.

Brasília, 2018 


\section{A associação livre em Freud: fundamento do tratamento psicanalítico}

Dissertação apresentada ao Programa de Pós-graduação em Psicologia Clínica e Cultura da Universidade de Brasília como requisito parcial à obtenção do título de Mestre em Psicologia Clínica e Cultura.

\section{Banca examinadora:}

Presidente:

Professor Dr. Luiz Augusto Monnerat Celes

Universidade de Brasília - UnB

Presidente

Membro:

Professora Dra. Estela Ribeiro Versiani

Escola Superior de Ciências da Saúde - ESCS

Membro Titular

Membro:
Professora. Dra. Tania Inessa Martins de Resende
Centro Universitário de Brasília - UniCEUB
Membro Titular

Suplente:

Dra. Iara Flor Richwin Ferreira

Secretaria de Estado de Políticas para Crianças, Adolescentes e Juventude - GDF Membro Suplente

Brasília, janeiro de 2018 
Àqueles(as) que, em algum momento, me confiaram suas palavras, ousaram fazer confidências. 


\section{Agradecimentos}

Lembro-me de algumas pessoas que contribuíram no caminho desta dissertação, cada uma delas à sua maneira.

Agradeço, primeiramente, ao Luiz Celes pela orientação e pelas discussões que fizeram valer o esforço que o mestrado representou. Por sua generosidade e incentivo sempre temperados com bom humor, pela companhia inspiradora de todos esses anos de descoberta e constantes reinvenções do sentido da psicanálise. Principalmente, por me ajudar a descobrir e a valorizar que é de trabalho que se trata, sempre.

Agradeço, também, à minha banca examinadora, Estela Versiani, Tania Inessa, e Iara Flor, por aceitarem o convite, por disporem de seu tempo para ler meus escritos e partilharem comigo suas reflexões.

Agradeço à Flávia, minha flávia. Para quem as palavras vão sempre me faltar para dizer o quanto se faz importante, o quanto é parte do que consigo ser. Por ter me apoiado quando o mundo parecia ruir, por confiar em minha capacidade de escrita e de trabalho. Por conseguir fazer da sua escuta carinhosa um dos únicos lugares em que consigo me encontrar e seguir adiante. Por, ao me permitir dividir a vida a seu lado, me ensina cotidianamente o que é o amor.

Agradeço à Barbara Andrade, vulgo Sanches, por saber estar perto mesmo longe. Pela escuta paciente das minhas insanidades e pela incrível capacidade de dar três tapas e me fazer voltar ao rumo certo. Por se fazer a irmã que pude escolher e por sua amizade tornar a vida muito mais divertida. 
Agradeço ao Marcio Nunes de Carvalho pela enorme paciência e escuta por anos. Por sua presença engajada, efetiva e afetiva, em me aproximar de quem sou, e mais ainda, de quem posso inventar ser.

Agradeço à minha mãe, Telma, que ao me mandar ser feliz, mostrou-me o norte do caminho; aos meus irmãos José e Liliana, que me fizeram cabeção na família e suportaram minhas faltas; a meu Pai, que mesmo ausente, é parte inexorável da força que me habita.

Agradeço, imensamente, aos meus amigos, parceiros de alegrias e dissabores da vida que suportaram comigo a sofrida renúncia de nossa convivência nos tempos de mestrado: Angelo Marcelo, irmão de sangue sem o ser, por conhecer de estar perto e entender da fina arte de se fazer presente; Renata Crispim, inspiração de inteligência e originalidade, que gentilmente colaborou com o abstract; Alexandre Arbex, que me contou que começar já é a metade do caminho e que a cada café ou partida de basquete partilhada me fazia reencontrar o tesão de continuar.

Agradeço a todos os colegas psicanalistas, pelos ensinamentos e trocas na psicanálise no correr desses anos. Por me fazerem e me aceitarem como um par. Em especial, ao grupo $53^{\circ}$ Margem, pelas discussões e liberdade criativa; à Lúcia Pimentel, por acreditar, ajudar e insistir que eu continuasse; às colegas do grupo de orientação, em especial Elise Alves, pelo incentivo e apoio mútuo nessa travessia.

Ao Spiga e ao Pinguim, pelas instintivas presenças de amor em minha vida. 
Ora, estas coisas psicanalíticas só são compreensíveis se forem relativamente completas e detalhadas, exatamente como a própria análise só funciona se o paciente descer das abstrações substitutivas até os ínfimos detalhes. Disso resulta que a discrição é incompatível com uma boa exposição sobre a psicanálise. É preciso ser sem escrúpulos, expor-se, arriscar-se, trair-se, comportar-se como o artista que compra tintas com o dinheiro da casa e queima os móveis para que o modelo não sinta frio. Sem alguma destas ações criminosas, não se pode fazer nada direito

Carta de Freud a Oskar Pfister, 5/6/1910 


\section{Resumo}

Esta dissertação discute a associação livre enquanto fundamento do tratamento da psicanálise para Freud. Procura-se acompanhar os caminhos pelos quais a associação livre se apresenta e vai progressivamente se firmando como regra fundamental do tratamento psicanalítico. Busca-se, ao mesmo tempo, compreender sua lógica intrínseca de funcionamento e as razões de sua eficácia para o tratamento do psiquismo, ele mesmo de natureza associativa. Por meio da retomada de alguns dos escritos freudianos, percebe-se como a concepção da regra técnica fundamental vai se modificando no decorrer da teorização sobre prática do psicanalista e toma o processo livre-associativo como organizador principal do enquadre proposto no método da psicanálise. A partir dos entraves estabelecidos nos tratamentos e teorizados por Freud em seus textos, constata-se como a regra da associação livre alcança sua elaboração enquanto fala associativa e assume o lugar de fundamento do trabalho de tratamento da psicanálise em Freud.

Palavras-chave: Freud; associação livre; regra fundamental; técnica psicanalítica; psicanálise. 


\begin{abstract}
This master thesis discusses the free association as the essential ground of Freud's psychoanalytical treatment. It seeks to understand the paths by which free association presents itself and is progressively established as the fundamental rule of psychoanalytic treatment. At the same time, it seeks to understand its internal logic of functioning and the reasons of its effectiveness in the treatment of the psyche, itself understood on its associative nature. Through the Freudian writings, it shows how the conception of the fundamental technical rule has been modified during the course of the psychoanalysis theory and practice and took place as the main organizer of the setting proposed in the method of psychoanalysis. From the obstacles established in the treatment and theorized in Freud's texts, it observes how the rule of free association reaches its elaboration as associative speech and assumes the essential ground of the work of psychoanalysis treatment in Freud.
\end{abstract}

Keywords: Freud; free association; fundamental rule; psychoanalytic technique; psychoanalysis. 


\section{Sumário}

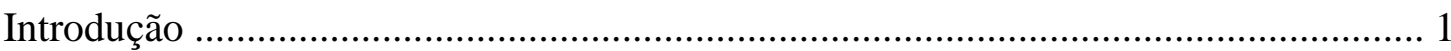

Capítulo 1 - A descoberta da associação "livre" - a fala que cura ................................ 8

1.1 A "mágica" das palavras - o aparelho associativo da linguagem ..................... 8

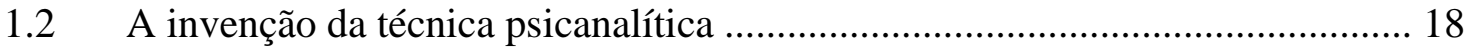

Capítulo 2 - Da associação livre à regra fundamental - o método de tratamento ......... 38

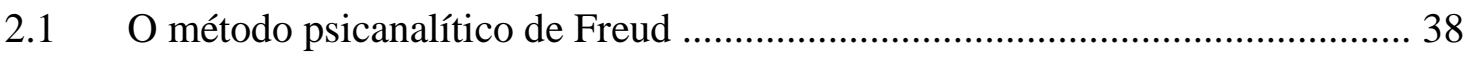

2.2 O tratamento na regra fundamental: primeiros desenvolvimentos .................. 56

Capítulo 3 - Associação Livre: fundamento do trabalho de Psicanálise ...................... 71

3.1 A técnica definida por sua ética fundamental .......................................... 71

3.2 Construções: a elaboração da regra enquanto fundamento ............................. 92

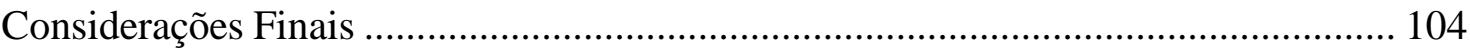

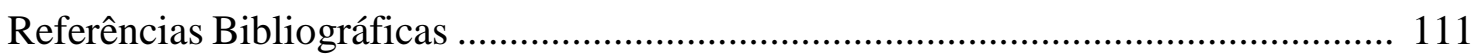




\section{Introdução}

Existirmos a que será que se destina?

Pois quando tu me deste a rosa pequenina Vi que és um homem lindo e que se acaso a sina

Do menino infeliz não se nos ilumina Tampouco turva-se a lágrima nordestina Apenas a matéria vida era tão fina

E éramos olharmo-nos intacta retina A cajuína cristalina em Teresina Caetano Veloso, Cajuína.

A bruxa freudiana, no decorrer de mais de um século de construção do pensamento psicanalítico, passou por mudanças, sofreu inúmeros acréscimos. Em vários momentos, a teoria que dá sustentação ao tratamento psicanalítico se deparou com limites que exigiram de Freud reformulações de sua metapsicologia. A introdução do conceito de narcisismo, a criação do modelo da segunda tópica, o surgimento do conceito de pulsão de morte e a descoberta de um masoquismo primário, por exemplo, marcam momentos de desdobramento e reconsideração da teoria freudiana que tentavam dar conta dos impasses encontrados nos tratamentos, mesmo que tais reformulações não significassem um abandono completo das ideias anteriores.

Freud, desde a célebre missiva a Fliess, de 21 de setembro de 1897, em que contou não acreditar mais em sua neurótica (Masson, 1986, p. 265), nunca se furtou a abandonar certas posições ou buscar novos caminhos quando o que encontrava na realidade dos tratamentos não correspondia a suas ideias. Seus herdeiros, os teóricos da Psicanálise pós- 
freudiana, seguiram repensando o psiquismo e suas vicissitudes, os conceitos fundamentais da psicanálise e de seu método de trabalho nos consultórios.

No entanto, mais de um século depois de sua criação, continuamos a sugerir a quem nos procura para uma psicanálise que, a cada encontro, nos conte, da forma mais livre possível, tudo o que lhe ocorre; tente não omitir, especialmente, o que parecer irrelevante ou constrangedor. Pedimos que "solte sua língua", fale de maneira desimpedida. Ao psicanalista cabe escutar o que lhe é dito fiando-se na mesma dinâmica: não atribuindo, a priori, qualquer relevância ou falta dela ao que ouve.

Nem Freud durante toda sua teorização, nem os que o seguiram pensando a psicanálise no correr dos anos e que, por ventura, criaram novos ramos a partir do tronco freudiano (Mezan, 2014), alteraram de modo substancial o fundamento técnico mais significativo do método psicanalítico - a associação livre. Trata-se, desde Freud até os dias atuais, da regra técnica fundamental do fazer psicanalítico, elemento central de seu método. Seu princípio implícito aponta que, em psicanálise, é unicamente no âmbito da dinâmica livre-associativa que algo do inconsciente pode se apresentar e, a partir de então, ser trabalhado, tratar o sujeito.

A regra de ouro da associação livre nunca foi, durante todo o processo de construção teórica da psicanálise efetuada por Freud em sua extensa obra, deslocada de seu lugar de fundamento da prática psicanalítica. A técnica do tratamento, ou, mais especificamente, o fundamento do método com o qual o analista trabalha concretamente no cotidiano do consultório, permaneceu balizado por esse modo específico de fala e de escuta desde sua criação.

No decorrer desta dissertação, utilizaremos o termo método para designar o conjunto mais amplo de processos ou modos de operar presentes no caminho de uma 
psicanálise, como, por exemplo, a interpretação, o manejo, a transferênciacontratransferência. Reservaremos o termo técnica para a parte propriamente prática presente no método, o procedimento peculiar ou específico observado para um determinado fazer, no caso: o fazer do tratamento em uma psicanálise.

Tal observação se faz pertinente na medida em que a referida distinção entre os termos método e técnica não é seguida por muitos dos autores que trataram sobre o tema da associação livre. Como veremos no decorrer deste trabalho, método psicanalítico e técnica psicanalítica são usados, muitas vezes, de forma indistinta e equivalente nas ideias apresentadas pelos teóricos. Ademais, julgamos que tal diferenciação se faz necessária na medida em que supomos que é precisamente na regra técnica livre-associativa que a psicanálise encontra o fundamento definidor de seu método. É no recurso à associação livre que ela se diferencia das outras práticas de tratamento pela palavra.

Ao separar a psicanálise das diversas psicoterapias, Mezan (1995) é categórico quanto à relevância da regra fundamental:

Eis aqui, portanto, um primeiro critério para distingui-las: o emprego ou recusa da livre-associação como forma de obter o material sobre o que se vai trabalhar; os desdobramentos desse critério são múltiplos e mais importantes do que poderia parecer à primeira vista. (Mezan, 1995, p.26)

Mezan (1995) apontou que a psicanálise foi colocada numa posição singular perante as demais práticas psicoterápicas ao abandonar a direção do tratamento ao paciente, submetendo-o à regra fundamental da associação livre: “esta posição especial da psicanálise a faz extravasar o gênero das psicoterapias e instalar-se num gênero 
próprio, do qual é a única representante" (p.25). Desde que a psicanálise foi inventada por Freud, a associação livre se estabeleceu como a regra técnica que singulariza o tratamento do tipo psicanalítico. Ainda que a técnica psicanalítica possa ser pensada como parte integrante de seu método, portanto englobada dentro desse, supomos que o enquadre proposto pelo tratamento psicanalítico freudiano funciona sempre em favor de promover o fundamento livre-associativo, nele encontrando sua definição essencial.

A historiografia da psicanálise nos relata que foi Emmy Von N, muito irritada com as constantes interrupções de sua fala nas consultas, a primeira paciente a pedir que Freud se calasse e a deixasse terminar o que tinha para lhe contar naquele dia. Foi a partir dessa experiência com Emmy ${ }^{1}$ - na verdade a Baronesa Fanny Moser - em 1890, bem como de outras tentativas de tratamento da histeria que Freud tentava empreender naquele período, que surgiu um prelúdio do que se viria a se firmar mais tarde como a regra técnica fundamental da Psicanálise. Algumas décadas depois, ao retomar esse momento fundador, relataria Freud que:

A nova técnica mudou de tal forma o quadro do tratamento, levou o médico a uma relação tão nova com o paciente e gerou tantos resultados surpreendentes, que foi justificado recorrer a um novo nome para distinguir esse procedimento do método catártico. O presente autor escolheu a denominação de psicanálise para esse modo de tratamento que podia se estender a muitas outras formas de distúrbios neuróticos. (Freud, 1923/2011, p.279)

1 Gay (1988/2004) nos conta da gratidão de Freud por Emmy, confessada a sua filha Anna, situando seu tratamento como um momento decisivo para a criação da terapia psicanalítica, aprendendo justamente dele a lição de que "o tratamento pela hipnose é um procedimento inútil e sem sentido" (Gay, 1988, p.81). 
O trecho sugere que o advento da inédita técnica não apenas obrigou Freud a encontrar outro nome para diferenciar o novo tratamento do método catártico - a psicanálise é filha, portanto, da técnica livre-associativa - como o fez perceber que o que tinha potencial de "tratar" nesse novo procedimento era justamente esse modo específico de se caminhar pelo psiquismo, orientado pela liberdade de fala do paciente.

Mezan (1995) chama a atenção para o fato de que, quando Freud afirma que o tratamento psicanalítico só poderia se propor a cura prática do doente, ele a define como o "estabelecimento de sua capacidade de agir e ter prazer" (p.27). Mezan (1995) nota que Freud não escreve que se trata de reestabelecer no paciente essa capacidade, mas, sim, de estabelecê-la, enfatizando que antes do tratamento ela não existia em ato.

Desse modo, para Mezan (1995), o tratamento em psicanálise tem um significado que se afasta da cura do tipo médico ou psicoterápico, entendidos como o restabelecimento de uma norma ou situação anterior. Nesse sentido, a cura (Kur) psicanalítica pressupõe a criação de uma situação que não estaria previamente presente, mas que teria que passar a existir. "Freud emprega a palavra Kur como sinônimo de Behandlung, isto é, de tratamento" (Mezan, 1995, p.27), aproximando, assim, o resultado do tratamento ao processo propriamente dito. Freud parece apontar que é no próprio processo trilhado de tratamento que se dá a cura em psicanálise. É no tratamento atravessado em associação livre pelo sujeito que a capacidade de agir e de ter prazer pode ser estabelecida.

Para Jorge (2017), a livre-associação é o núcleo candente que rege todas as operações clínicas da psicanálise. Entre os anos de 1890 e 1937, confrontado com a experiência do consultório, Freud mapeia e delineia os elementos essenciais da prática psicanalítica - definindo seu método, ao mesmo tempo que elabora os conceitos de 
inconsciente, pulsão, fantasia, sintoma e etc. "Nessa construção, o papel desempenhado pela regra da associação livre não poderia ser maior, razão pela qual Freud a denominará regra fundamental da Psicanálise” (p. 17).

Procuramos neste trabalho, portanto, tentar acompanhar por quais caminhos a associação livre se apresentou e foi progressivamente se firmando para Freud como regra fundamental do tratamento psicanalítico. Buscamos, ao mesmo tempo, compreender sua lógica intrínseca de funcionamento e as razões de sua eficácia para o tratamento do psiquismo. Por meio da retomada de alguns dos escritos freudianos, perceberemos como a concepção da regra técnica fundamental foi se modificando no decorrer de sua teorização sobre prática do psicanalista e tomando o processo livre-associativo como organizador principal do enquadre proposto no método da psicanálise. A partir dos achados e dos entraves estabelecidos nos tratamentos para Freud e teorizados em seus textos, perceberemos como a regra da associação livre foi alcançando sua elaboração enquanto fala associativa e assumindo o lugar de fundamento essencial do trabalho de tratamento da psicanálise.

Dividimos o presente trabalho em três capítulos, cada um deles subdividido em duas partes. No primeiro capítulo, abordaremos os primórdios da psicanálise e as reflexões empreendidas por Freud acerca das relações entre a linguagem e o psiquismo no processo terapêutico; veremos que ele propõe, antes de sua teoria do aparelho psíquico, uma concepção de um aparelho de linguagem dinâmico, cuja base de funcionamento era essencialmente associativa. Também abordaremos de que maneira, a partir do discurso livre-associativo que se impôs a Freud no tratamento da histeria, foi sendo, a um só tempo, descoberta e inventada a técnica psicanalítica em suas potencialidades para tratar o psiquismo. 
A partir da investigação dos sonhos empreendida por Freud e da teoria do psiquismo dela decorrente, veremos, em nosso segundo capítulo, a associação livre assumindo o lugar de regra técnica fundamental no novo método de tratamento psicanalítico. Mais adiante, nos deteremos, no modo como, neste recém-criado método psicanalítico freudiano, a regra fundamental o diferenciava do modelo clínico anterior da histeria e os desenvolvimentos de sua apropriação na prática concreta dos tratamentos de Dora e do Homem dos Ratos.

Por fim, em nosso terceiro capítulo, mostraremos como na livre-associação a técnica psicanalítica proposta por Freud em seu método encontrou não apenas seu enquadre definidor, mas também uma dimensão ética que a singulariza enquanto modo específico de tratamento e de investigação. Abordaremos, também, a fase final da teorização freudiana sobre prática do psicanalista, proposta em Construções na análise, vislumbrando ali um alargamento do alcance e dos efeitos que a associação livre tem para o trabalho da análise, bem como sua elaboração final enquanto fundamento do tratamento psicanalítico.

Em nossas considerações finais, retomaremos o percurso geral do trabalho e as ideias principais desenvolvidas em cada um dos capítulos, apresentando, por fim, o que nos parece ser o estatuto específico e singular da associação livre na psicanálise freudiana. 


\title{
Capítulo 1
}

\section{A descoberta da associação "livre" - a fala que cura}

\author{
O mundo não marcha senão pelo mal-entendido. É \\ pelo mal-entendido universal que o mundo inteiro se \\ entende. Pois se, por desgraça, os homens se \\ compreendessem, não poderiam jamais entender-se.
}

Charles Baudelaire, Meu coração desnudado.

\subsection{A "mágica" das palavras - o aparelho associativo da linguagem}

A potência da troca de palavras no contexto clínico já era notada por Freud bem antes da técnica da associação livre se firmar como regra fundamental. No artigo Tratamento Psíquico (tratamento anímico), de 1890, ainda tributário do uso do método hipnótico, Freud menciona a existência de um poder 'mágico' nas palavras:

Agora começamos a entender também a 'magia' da palavra. Palavras, como sabemos, são os mais importantes mediadores da influência que uma pessoa quer ter sobre a outra, palavras são um bom meio para provocar transformações anímicas naquele a quem elas são dirigidas, e por isso não soa estranho quando se afirmar que a magia da palavra pode afastar manifestações de doenças, ainda mais aquelas que se originam em estados anímicos. Todas as influências anímicas que 
se mostraram eficazes para eliminar doenças têm algo de imponderável. (Freud, 1890/2017, p. 31)

Nesse artigo, Freud (1890/2017), ao destacar a importância do valor terapêutico da linguagem e da palavra no tratamento físico e mental, parece já vislumbrar os limites da hipnose para esse fim, relacionando-os à problemática utilização da sugestão presente no método hipnótico ${ }^{2}$. Sobre o texto de 1890, nos diz Jorge (2017) que esse parece já conter todo um projeto clínico que Freud virá a desenvolver minuciosamente ao longo de sua obra posterior: "ao demonstrar uma particular apreensão da relação intima entre os fenômenos transferênciais e o poder da palavra, Freud já está estabelecendo as bases do método psicanalítico" (p. 20).

Cerca de cinco anos antes, ao retornar do estágio feito com o neurologista JeanMartin Charcot em Paris entre 1885-1886, a visão clínica de Freud já havia sofrido uma reviravolta radical. Charcot sustentava que a observação clínica deveria se manter independente em relação à medicina teórica, isto é, à anatomia e à fisiologia. Esse apego à soberania da clínica parece ter marcado em definitivo o método de investigação do jovem Freud. De modo que, após abandonar a hipnose, Freud inaugurou a via para uma outra clínica, diferente e inédita, não aquela proposta por Charcot de ver clinicamente, mas a de ouvir.

\footnotetext{
2 Sobre o texto de 1890, nos conta a nota do editor Gilson lannini que "No início de sua prática clínica em Medicina, que remonta a alguns anos antes, Freud empregou diversos recursos terapêuticos então usuais, incluindo a eletroterapia e a hidroterapia, antes de se inclinar em direção a outros métodos que privilegiavam aspectos da influência ou da fala, tais como a hipnose, a sugestão e o método catártico (ab-reação). Àquela altura, no mundo médico, e especialmente em Viena, a validade da hipnose como método terapêutico era bastante controversa, encontrando no professor Theodor Meynert um forte opositor" (p. 44).
} 
A hipnose partia do princípio de que o sintoma neurótico poderia ser curado pela força das palavras do médico. Para Jorge (2017):

O abandono da hipnose e a concepção e a entronização da associação livre como regra fundamental da psicanálise estão interligados, pois aquilo que a hipnose pretende suplantar de forma artificial - a resistência -, a psicanálise não abre mão de vencer passo a passo ao longo do processo de tratamento. (Jorge, 2017, p. 27)

A hipnose lançava o sujeito em um lugar ideal em que a resistência era reduzida a zero; no entanto, passado seu efeito, os sintomas retornavam. Freud já apontava seu entendimento dos limites e dos problemas do método hipnótico baseados na sugestão ao final do artigo de 1890:

Outra forma como a relativa fraqueza da sugestão se revela em comparação às afecções a serem combatidas é que a sugestão consegue a suspensão das manifestações da doença, mas apenas por pouco tempo. Após decorrido esse período, os sinais de sofrimento voltam e precisam ser eliminados por uma nova hipnose com sugestão. Se esse percurso se repetir com uma frequência razoável, geralmente se esgotará a paciência tanto do doente como do médico e terá como consequência a desistência do tratamento hipnótico. Esses são também os casos em que se costumam estabelecer no doente a dependência do médico e uma espécie de vício pela hipnose. ... é facilmente compreensível que os médicos a quem o tratamento anímico hipnótico prometia muito mais do que podia cumprir não se cansem de buscar outros procedimentos que possibilitem uma intervenção 
mais profunda ou menos imprevisível na alma do doente. (Freud, 1890/2017, p.43)

Percebe-se que Freud, sem negligenciar o valor terapêutico da troca de palavras, notava que existiam elementos no método hipnótico que não possibilitavam se alcançar, a contento, uma terapêutica duradoura e eficaz. Os limites percebidos por Freud, já em 1890, deixavam em aberto o caminho para se encontrar algo que suplantasse os problemas apresentados pelo método hipnótico. Um ano depois, Freud publicaria um livro em que dava continuidade às suas reflexões sobre as relações entre a linguagem e o psiquismo.

Ao estudo Sobre a Concepção das Afasias, de 1891, texto escrito antes do surgimento do termo Psicanálise e excluído da edição das obras completas de Freud, é geralmente atribuído um teor mais neurológico que propriamente psicanalítico. Centra-se em uma discussão de Freud com a Neurologia da época acerca dos distúrbios referentes à compreensão e/ou articulação da linguagem: as afasias, em especial as doutrinas que buscavam localizar apenas nas estruturas físico-biológicas a problemática em questão.

Ao lado da discussão empreendida por Freud da problemática das afasias na perspectiva médico-neurológica, nesse estudo podem ser encontrados certos fundamentos da relação entre a linguagem e o psiquismo, além de uma concepção dinâmica de seu funcionamento, presentes no pensamento freudiano posterior. Também no estudo, pode ser vislumbrada a importância atribuída à linguagem desde os primórdios das preposições freudianas acerca do funcionamento e da estruturação do psiquismo.

Devido a sua importância, o editor das referidas obras completas, James Strachey, fez constar, em anexo, apêndices contendo elaborações feitas por Freud nesse trabalho no 
texto metapsicológico $O$ inconsciente, de 1915. Em relação ao livro Sobre a Concepção das Afasias, Rossi (2013) nos sugere que:

Vemos que em 1891 Freud se encontra preocupado com questões concernentes à dinâmica associativa das representações que compõem o substrato da linguagem. Ele já percebe com clareza a insuficiência de esquemas que buscam correlacionar distúrbios orgânicos, localizados em áreas do córtex, aos sintomas que se pretendem elucidar. Assim sendo, ele passa a buscar respostas para esclarecer os distúrbios afásicos a partir de uma perspectiva dinâmica, sendo impelido a conceber seu aparelho de linguagem (Sprachapparat), que é, sem dúvida, o 'irmão mais velho’ do aparelho psíquico" (Rossi, 2013, p. 155)

No que tange à problemática em questão neste trabalho, chama a atenção que Freud propôs, antes de sua teoria do aparelho psíquico, uma concepção de um aparelho de linguagem (Sprachapparat) dinâmico e cuja base de funcionamento estaria no modo associativo das representações contidas na linguagem. Sobre o mesmo texto freudiano, Tavares (2013) destaca que ele dá lugar às abstrações estruturais-funcionais que fazem da própria linguagem o substrato para a compreensão do psiquismo e que se pode perceber nele "a origem do conceito de associação [Assoziation] posteriormente utilizado para nomear o método clínico da livre associação de ideias através da fala no divã” (p.10).

A explicação trazida neste estudo, de que os distúrbios afásicos se deviam sobretudo a rupturas entre associações normais de representação no psiquismo, permite vislumbrar o que seria a essência do que Freud denominava como "aparelho de linguagem": algo que se centrava e fundamentava justamente no modo de funcionamento 
associativo do psiquismo. Segundo Rossi (2013), "Freud rejeitou esse modelo anatomopatológico de explicação do funcionamento da linguagem, enfatizando a dinâmica associativa simbólica-imagética subjacente a ele, desvelada então por seu aparelho de linguagem" (p.160).

Para apresentar o funcionamento do que nomeava como aparelho de linguagem, Freud (1891/2013) teve que se apropriar do argumento da Psicologia da época, segundo o qual a palavra seria a unidade mínima da função da linguagem. A palavra era tida como uma representação complexa, composta de elementos visuais, acústicos e cinestésicos.

As imagens componentes da representação de palavra seriam a imagem de som, a imagem visual das letras, a imagem de movimento da fala e a imagem de movimento da escrita. À palavra, pois, corresponderia um processo associativo do qual participariam conjuntamente os supracitados elementos visuais, acústicos e cinestésicos constitutivos. A palavra só adquiriria um significado, entretanto, em conexão com uma representação de objeto, que seria por sua vez um outro complexo associativo composto das mais variadas representações visuais, acústicas, táteis, cinestésicas e etc.

Logo no início de seu estudo, ao se referir às parafasias (confusão de palavras), Freud (1891/2013) ressalta que, quando observadas em pessoas enfermas, essas não diferem em nada das trocas de palavras ou de sua mutilação que se pode observar em pessoas saudáveis em função do cansaço: "Parece-nos apropriado considerar a parafasia, em sua abrangência mais ampla, um sintoma puramente funcional, um indício da capacidade de desempenho menos acurada do aparelho associativo da linguagem" (p. 31).

Note-se que Freud fala de um aparelho de linguagem que é associativo por natureza e que pode sofrer interferências e influências de outros conteúdos psíquicos. Por parafasias, nos diz, deve-se necessariamente entender um distúrbio na fala na qual a 
palavra apropriada é substituída por uma inapropriada, mas que, contudo, mantém sempre uma certa relação com a palavra correta:

Trata-se de parafasia quando o falante utiliza uma palavra em vez de outra, que sejam ligadas uma à outra por meio de associação frequente, por exemplo, quando ele usa pena em vez de lápis, Potsdam em vez de Berlim. Além disso, quando ele confunde palavras que têm sons semelhantes, manteiga [butter] em vez de mãe [mutter] .... Fica-se tentado, diante dessas diversas formas de parafasia, a se diferenciar entre elas com base no local no aparelho de fala [Sprechapparates] em que o atabalhoamento se introduziu. Além disso, deve-se denominar também parafásico quando duas intenções de fala fundem-se, produzindo uma palavra deformada, como pãe [vutter] para mãe [mutter] ou pai [vater]. (Freud, 1891/2013, pp.41-42)

Tavares (2013) julga digno de nota que, nos exemplos escolhidos por Freud para o trecho, possamos vislumbrar claramente os conceitos de deslocamento e condensação que posteriormente sustentarão o entendimento de uma gramática do inconsciente relacionada ao recalque e às substituições de representação, curiosamente já se valendo das palavras referentes às figuras parentais naquele momento. No entanto, são as variadas e sempre presentes relações de ligação percebidas entre as palavras - por proximidade, semelhança de som e etc., portanto de associação - encontradas nos distúrbios afásicos e apontadas por Freud como características do aparelho de fala que mais nos chamam a atenção nesse momento. 
Ao retomar os trabalhos de Grashey sobre a compreensão dos distúrbios de leitura, Freud (1891/2013) afirma que o autor "nos deu, pela primeira vez, uma ideia da complexa e tortuosa sequência de associações, múltiplas em suas direções, no processo de linguagem" (p. 64). Parece ser dessa perspectiva, de um aparelho de fala que funciona em um modo associativo complexo, que Freud retira a base e a força de seu argumento para romper com as teorias da Neurologia então vigentes nos estudos das afasias da época:

Rejeitamos, pois, a suposição de que o aparelho de linguagem seja constituído de centros distintos, separados por territórios corticais sem função e, além disso, que representações (imagens de lembranças) que servem à linguagem ficam armazenadas em determinadas áreas do córtex, denominadas de centros, enquanto a associação dessas representações é feita exclusivamente por fibras de substância branca subcorticais. Então, resta-nos agora expor a ideia de que o território da linguagem no córtex é um distrito contínuo, dentro do qual as associações e transferências, nas quais se baseiam as funções da linguagem, ocorrem em uma complexidade cujos detalhes exatos escapam à compreensão. (Freud, 1891/2013, p.86)

Freud (1891/2013) é ainda mais enfático ao afirmar que "todas as afasias se baseiam na interrupção de associações, ou seja, na interrupção de vias de condução" (p.92). Ou seja, para Freud, a causa das afasias, em última instância, se devia não a uma disfunção de ordem orgânica, mas principalmente a um distúrbio no processo de associação, um distúrbio associativo ocorrido entre as representações de palavra e representações de objeto que acompanham cada uma das tarefas da linguagem - o falar, 
o soletrar, o ler, o escrever. "A palavra é, então, uma representação complexa que consiste nas imagens mencionadas, ou dito de outra forma, à palavra corresponde um intricado processo associativo [assoziationsvorgang] para o qual concorrem os referidos elementos de origem visual, acústica e cinestésica" (p. 102).

Depreende-se de toda a argumentação freudiana nesse texto de 1891 a concepção de um aparelho de linguagem cuja unidade mínima - a palavra - é tributária de uma complexa e dinâmica rede associativa ainda não completamente conhecida, na qual as mais diversas perturbações e interferências terão como resultado os vários tipos de afasias descritos no estudo. Ou seja, Freud (1891/2013) vincula seu aparelho de linguagem à característica inerentemente associativa de seu funcionamento, localizando nas variações de seu desempenho a diversidade dos fenômenos que se propõe a elucidar.

Ainda que, nesse momento, tais questões não levem Freud à proposição de uma terapêutica daí derivada, ao postular a noção de um aparelho de linguagem, cuja associatividade constitutiva parece ser a chave para se entender as afasias, Freud deixa vislumbrar seu interesse pela complexidade dos fenômenos da linguagem e seus potenciais efeitos para o tratamento do psiquismo.

Em seu estudo de 1891, Freud vai apontando o emaranhado de correlações associativas presentes no aparelho de linguagem que propõe, enfatizando as vias de acesso alternativas e a capacidade de plasticidade dos distúrbios de fala em cada um dos tipos de afasia. Fazendo, desse modo, pensar em um aparelho de linguagem que seria, em última instância e originalmente, um aparelho associativo, que funciona essencialmente por meio de uma dinâmica associativa.

Ao avaliar a função do aparelho de linguagem sob condições patológicas, nos diz que "sob todas as condições, um arranjo de associações mais elevado, desenvolvido 
posteriormente, será perdido, e um arranjo de associações mais simples, adquirido anteriormente, ficará preservado" (Freud, 1891/2013, p.112). Mais adiante, complementa Freud (1891/2013): “A maioria dos aspectos aqui listados resulta das particularidades gerais de um aparelho preparado para a associação" (p.115).

Já apontando os caminhos que suas reflexões trilhariam nos anos seguintes, especialmente no estudo sobre as histerias, Freud, no final do artigo de 1891, menciona a influência de Charcot em seu pensamento ao afirmar que "Partimos do pressuposto de que, a despeito da possibilidade de associação em todas as direções entre os elementos da função da linguagem, o que ocorre, entretanto, é que, na atividade funcional, certas direções de associação são privilegiadas" (Freud, 1891/2013 p.125).

Se para Freud (1891/2013) as associações entre palavras estariam, de algum modo, na origem de formação do sintoma, sua terapêutica seria centrada no uso 'mágico' das palavras, como já apontava as reflexões de seu artigo do ano anterior: Tratamento Psíquico (tratamento anímico). O nascimento da psicanálise como método de tratamento da histeria é tributário da percepção dessas direções privilegiadas do processo associativo da linguagem notadas por Freud em Sobre a Concepção das Afasias. Para Forrester (1983) a obra de Freud sobre as afasias é o sine qua non da origem da teoria psicanalítica: "uma teoria do poder das palavras para a formação dos sintomas" (p.37).

Ainda tateando um método de tratamento que pudesse dar conta das enfermidades que encontrava no consultório, Freud, em Algumas considerações para o estudo comparativo das paralisias motoras orgânicas e histéricas, de 1893, conclui que a paralisia histérica era causada pela fixação numa associação não consciente, uma lembrança traumática que precisaria ser trazida à consciência e eliminada de sua carga afetiva. Isto poderia ser feito por meio de uma reação motora adequada ou pela atividade 
psíquica consciente, ou seja, através da fala, o que era chamado de ab-reação. Tal ideia constituiu um resumo da teoria que foi apresentada em Sobre o mecanismo psíquico dos fenômenos histéricos: comunicação preliminar, escrita juntamente com seu mestre Josef Breuer em dezembro de 1892.

\subsection{A invenção da técnica psicanalítica}

Em 1895, é publicada a obra Estudos sobre a histeria, na qual Freud, em coautoria com Breuer, apresenta cinco relatos de tratamento de pacientes histéricas. Foi uma delas, Anna O., quem se referiu ao método de tratamento utilizado com ela por Breuer - catarse e ab-reação - de talking cure (cura pela fala) e de chimney sweeping (limpeza de chaminé). Foi o próprio Breuer quem percebeu, ao descrever a história clínica do caso de Anna O., que seus sintomas eram "eliminados pela narração" (Breuer \& Freud, 1895/2016, p.60) quando recebiam uma expressão verbal. E foi também Breuer quem acrescentou uma observação interessante no caso de Anna O., que remete à bronca dada por Emmy Von N em Freud, citada em nossa introdução, e ao papel relevante que a técnica da associação livre teria na futura psicanálise:

Revelou-se totalmente impraticável abreviar a coisa tentando evocar diretamente o primeiro motivo precipitador dos sintomas em sua lembrança. Ela não encontrava, ficava confusa, tudo caminhava com mais lentidão ainda do que se a deixassem, com calma e segurança, desenrolar retrospectivamente os fios da lembrança abrangidos. (Breuer \& Freud, 1895/2016, p.60) 
Já no primeiro capítulo dos Estudos sobre a histeria: Sobre o mecanismo psíquico dos fenômenos histéricos ${ }^{3}$, Breuer aponta que havia uma conexão causal entre os fenômenos patológicos apresentados na histeria e um evento desencadeador, via de regra, desconhecido pelo doente:

Muitas vezes a conexão é tão clara que fica evidente a razão pela qual o incidente motivador gerou esse fenômeno e não outro. Esse foi, de maneira totalmente clara, determinado pelo motivo precipitador. ... Em outros casos a conexão não é tão simples; existe apenas uma relação simbólica, por assim dizer, entre o motivo precipitador e o fenômeno patológico, como a que uma pessoa sã forma no sonho, quando por exemplo, uma nevralgia se associa a uma dor psíquica ou vômito ao afeto de repugnância moral. (Breuer \& Freud, 1895/2016, pp. 20-21)

Ou seja, de início já nos é informado que, não apenas existia algo de associativo na base dos sintomas apresentados pela histérica, mas que, em vários casos, essa conexão não era simples e se apresentava simbolicamente determinada, comparando-a com o que acontecia no sonho. Assim, existia algo da relação entre o psiquismo e o corpo que continha um fundamento associativo, por vezes simbólico, que estava na base do adoecimento histérico. E a busca do médico se orientava por encontrar essa associação, esse vínculo ou conexão:

3 Publicado originalmente por Breuer e Freud em 1893 na forma de Comunicação Preliminar 
Pois vimos, para nossa grande surpresa inicial, que cada sintoma histérico desaparecia de imediato e sem retorno, quando conseguíamos despertar com toda clareza a lembrança do acontecimento motivador, assim avivando igualmente o afeto que o acompanha, e quando, em seguida, o doente descrevia o episódio da maneira mais detalhada possível, pondo o afeto em palavras. Recordar sem afeto é quase sempre ineficaz. (Breuer \& Freud, 1895/2016, p.23)

Se o "histérico sofre sobretudo de reminiscências" (Breuer \& Freud, 1895/2016, p.25), ou seja, se sofre principalmente de lembranças que não podem ser lembradas, que por sua vez estabelecem as associações inconscientes presentes nos sintomas, a cura da histeria viria ao se "despertar" a lembrança por meio de "palavras", de maneira "mais detalhada possível", "pondo" o afeto em palavras. A tese apresentada por Breuer e Freud logo na abertura dos Estudos sobre a histeria apontava que a terapêutica envolvida na histeria passava pela construção consciente, por meio da fala do doente, de uma associação entre o evento motivador - uma lembrança, e o afeto que o acompanhava originalmente. Palavra associada a afeto. Uma palavra dita pelo doente e encarnada pelo afeto. Sem isso, apontou Freud, o tratamento seria ineficaz.

Nas duas situações apresentadas em Estudos sobre a histeria como desencadeadoras do adoecer histérico - sejam aquelas derivadas de traumas psíquicos que geraram supressão de conteúdos penosos, sejam nas causadas por estados hipnoides - a causa do adoecimento se dava porque "as ideias que neles surgem são muito intensas, mas fechadas ao tráfego associativo [grifo nosso] com o resto da consciência". (Breuer \& Freud, 1895/2016, p.31). O que Breuer e Freud parecem notar são as falhas no processo associativo presentes na histeria: 
É comum aos dois grupos de condições, porém, que os traumas psíquicos não resolvidos por meio de reação também não o possam ser por elaboração associativa. No primeiro grupo é o propósito que quer esquecer as vivências penosas e as exclui da associação tanto quanto possível; no segundo grupo esse processamento associativo fracassa porque não existe abundante vínculo associativo entre o estado de consciência normal e os patológicos, em que surgiram essas ideias. Pode-se dizer, portanto, que as ideias que se tornaram patogênicas conservam-se tão frescas e vigorosamente afetivas porque o desgaste normal pela ab-reação e pela reprodução em estados de desimpedida associação [grifo nosso] lhe é negado. (Breuer \& Freud, 1895/2016, p.30)

Breuer e Freud nos falam de "tráfego associativo", "elaboração associativa" e “desimpedida associação", dando a entender que a associação entre ideias, e entre ideia e afeto, não era livre na histeria, mas de algum modo travada, impedida. O tratamento consistiria em reverter essa tendência dissociativa presente na histeria, restaurar um livre tráfego associativo, e, possibilitando novas operações associativas no psiquismo, livrar a histérica de seus sintomas. Mesmo a noção apresentada nesse momento da existência de conteúdo de natureza inconsciente passava, de algum modo, pela noção de associação presente no psiquismo: "na histeria estão presentes grupos de ideias originados em estados hipnoides que, excluídos do trânsito associativo com os demais, porém associáveis entre si, constituem um rudimento mais ou menos altamente organizado de uma segunda consciência, de uma condition seconde" (Breuer \& Freud, 1895/2016, p.36). 
Strachey (1969/1987), em suas considerações ao texto freudiano, afirma que se tornou patente, desde o início, que o problema não era meramente a investigação dos processos mentais conscientes, para a qual bastariam os métodos corriqueiros de indagação empregados na vida cotidiana. Se havia também processos mentais inconscientes, era claramente necessário algum instrumento especial. "O instrumento óbvio para esse fim era a sugestão hipnótica - a sugestão hipnótica utilizada não para finalidades diretamente terapêuticas, mas para persuadir o paciente a produzir material proveniente da região inconsciente da mente" (Strachey in Breuer \& Freud, 1895/1987, pp.23-24)

Portanto, a hipnose, o uso da técnica hipnótica no método, era antes um meio de investigação disponível para se chegar aos conteúdos inconscientes que o instrumento terapêutico por excelência que produzia a cura. Nas palavras de Breuer e Freud, o que curava era a "correção associativa" (Breuer \& Freud, 1895/2016, p.38) produzida a partir do método. Dizendo de outro modo, a hipnose era o meio que dispunham, naquele momento, para alcançar o material inconsciente e recolocá-lo em livre trânsito associativo com o resto da consciência. Freud usava a hipnose, sobretudo, para que suas pacientes falassem.

Nos quatro casos clínicos seguintes apresentados por Freud em Estudos sobre a histeria, depois do de Anna O., pode-se constatar um evidente interesse de Freud pela reconstrução da história dessas pacientes, a incitação para que falassem, uma atenção especial às significações implicadas em suas falas, ao momento em que elas, por qualquer razão, se interrompiam. Para Lacan (1953/1986), essa obra apresenta "uma longa exposição da descoberta da técnica analítica" (p.17) e é justo isto que constitui seu valor: neles a técnica psicanalítica achava-se em formação. 
No relato do segundo caso dos Estudos sobre a histeria, a Sra. Emmy Von N. nos é apresentada e descrita por Freud como uma excelente paciente para o hipnotismo: "bastou eu levantar um dedo diante dela e ordenar-lhe que dormisse para que se reclinasse com a expressão atordoada e confusa" (Breuer \& Freud, 1895/1987, p.81). No entanto, Freud não se limitava a escutar com relevância o que era dito apenas em hipnose e extrair daí suas diretrizes no tratamento: "Ela me entreteve, em estado que parecia normal, com histórias aterradoras sobre animais. ... Compreendo agora por que tantas vezes ela me entretém com cenas de animais e quadro de cadáveres. Minha terapia consiste em eliminar esses quadros" (Breuer \& Freud, 1895/1987, pp. 82-83). Em um trecho, especialmente interessante, Freud percebe algo no tratamento de Emmy:

Também a conversa que mantém comigo enquanto é massageada não é tão desprovida de intenção como parece; pelo contrário, contém a reprodução bastante completa das lembranças e novas impressões que a influenciaram desde nossa última entrevista e, com frequência, de modo bastante inesperado, acaba em reminiscências patogênicas, sobre as quais fala sem que eu tenha lhe solicitado. É como se tivesse se apropriado do meu procedimento e utilizasse a conversa, aparentemente natural e guiada pelo acaso, como complemento da hipnose. Assim, por exemplo, hoje fala de sua família e, por toda sorte de rodeios, chega à história de um primo excêntrico e obtuso, a quem os pais mandaram arrancar todos os dentes de uma assentada. (Breuer \& Freud, 1895/2016, pp. 86-87)

Talvez seja o fragmento acima a primeira descrição na obra de Freud do que mais tarde se entenderia como a técnica da associação livre, feita espontaneamente por Emmy 
e percebida, não sem surpresa, por Freud. Fora da hipnose, a conversa com a paciente não era tão "desprovida de intenção" como aparentava e frequentemente, por um caminho tortuoso, desembocava nas lembranças que a hipnose tentava encontrar. O que Freud parecia ir descobrindo aos poucos era que a conversa "aparentemente natural e guiada pelo acaso" que tinha com Emmy deixava perceber uma determinação inconsciente na fala espontânea. O fio narrativo se desenrolava sempre de um modo associativo, determinado por ligações, ainda que essas fossem desconhecidas por ela.

Freud acrescenta, um pouco mais adiante em seu relato do caso de Emmy, que a havia interrompido após sua primeira história, em um momento em que ela se queixava de medo dos hospícios: "Vi então que nada tinha ganho com essa interrupção e que não posso me furtar a escutar suas histórias com todos os detalhes até a última palavra" (Breuer \& Freud, 1895/1987, p. 90). Além de ter que lidar com as queixas explícitas de uma Emmy zangada quando ele ousava lhe interromper, o que Freud descobria, na prática, era que parecia existir a necessidade de que fossem percorridos todos os pensamentos vinculados a um determinado tema, sob pena de que, de outro modo, os sintomas vinculados a eles não desapareciam por completo e Emmy retornava novamente ao assunto. Freud notava seu erro quando tentava encurtar o caminho. Além disso, o autor se atentou também para algo que acontecia quando deixava Emmy seguir sua cadeia de pensamentos:

A transição de um estado normal para um delírio ocorria muitas vezes de forma imperceptível. Num dado momento, ela ia conversando de modo perfeitamente racional sobre assuntos de pequena importância emocional e, à medida que a conversa passava para uma ideia de natureza aflitiva, eu notava por seus gestos 
exagerados ou pelo surgimento de suas fórmulas habituais de fala, etc., que ela se encontrava num estado de delírio. (Breuer \& Freud, 1895/1987, p. 118)

Emmy entrava em delírio ao seguir o livre curso de seus pensamentos na conversa com Freud. Ao percorrer sua cadeia associativa de modo livre, algo acontecia. Freud assim entende o que observa: "Em tais estados - e as poucas observações que fiz não me conduziram a nenhuma outra conclusão - havia uma limitação da consciência e uma compulsão a associar, semelhante à que predomina nos sonhos" (Breuer \& Freud, 1895/1987, p. 118).

Ainda que não o tenha desenvolvido plenamente nesse momento, Freud se atenta para a perspectiva dinâmica da movimentação psíquica colocada em ação quando Emmy falava de forma livre e seguindo o curso de seus pensamentos. É interessante observar que Freud nota e nomeia uma 'compulsão à associação' perceptível na fala de Emmy. Em uma longa nota de rodapé, disserta sobre o alcance dessa compulsão que surge vinculada a momentos de grande angústia e é capaz de promover 'falsas' ligações entre conteúdos ideativos:

Parece haver uma necessidade de se colocar fenômenos psíquicos que se tornam conscientes em ligação causal com outro material consciente. Ali onde a verdadeira causa foge à percepção da consciência, a pessoa não hesita em fazer outra ligação em que ela própria acredite, embora seja falsa. ... Recentemente, fazendo observações em outro domínio, pude me convencer do poder de tal compulsão à associação. Por várias semanas tive que trocar minha cama habitual por um leito mais duro, no qual provavelmente sonhei mais ou de modo mais 
vívido, ou, talvez, apenas não pude atingir a profundidade normal do sono. No primeiro quarto de hora após o despertar, sabia todos os sonhos da noite e me dava ao trabalho de anotá-los e tentar decifrá-los. Consegui relacionar todos esses sonhos a dois fatores: 1. à necessidade de elaboração daquelas ideias nas quais, durante o dia, havia me detido fugazmente, que haviam sido apenas roçadas e não resolvidas; 2. à compulsão de ligar entre si as coisas presentes no mesmo estado de consciência. À livre atuação desse último fator devia-se atribuir o sem sentido e contraditório dos sonhos. (Breuer \& Freud, 1895/2106, pp. 102-104)

Freud notava, em Emmy e em si mesmo, a existência no psiquismo de uma força que compelia à associação entre conteúdos, ainda que através de falsas ligações. Uma compulsão a associar submetida "à necessidade de elaboração daquelas ideias". Em outras palavras, o que Freud parecia perceber e descrever nesse momento era uma necessidade ou tendência psíquica de efetuar ligações entre ideia ou lembrança presente no psiquismo, uma necessidade desse mesmo psiquismo de alcançar uma elaboração pela via associativa.

É digno de nota, também, que um primeiro lampejo do fenômeno da transferência nos Estudos sobre a histeria seja observado por Freud sob a mesma ótica das 'falsas ligações’ e da compulsão a associar. Ao contar sobre uma paciente que tem o desejo de beijar-lhe em uma consulta, relata:

O desejo assim presente foi então, graças à compulsão a associar que era dominante na consciência, ligado a minha pessoa, na qual a paciente estava legitimamente interessada; e como resultado dessa mésalliance - que descrevo 
como 'falsa ligação' - provocou-se o mesmo afeto que forçara a paciente, muito tempo antes, a repudiar esse desejo proibido. Desde que descobri isso, tenho podido, todas as vezes que sou pessoalmente envolvido de modo semelhante, presumir que uma transferência e uma falsa ligação tornaram a ocorrer. (Breuer \& Freud, 1895/1987, p.292)

O problema com o uso do método hipnótico era tanto maior na medida em que nem todas as pacientes apresentadas nos Estudos sobre a histeria entravam em hipnose.

Em minhas tentativas de aplicar mais amplamente o método de Breuer depareime com a dificuldade de que muitos pacientes não eram hipnotizáveis, embora seu diagnóstico fosse de histeria e parecesse provável que o mecanismo psíquico por nós descrito atuasse neles. Eu precisava da hipnose para ampliar-lhes a memória, a fim de descobrir as lembranças patogênicas que não estavam presentes em seu estado comum de consciência. Assim, eu era obrigado a desistir da ideia de tratar tais pacientes, ou me esforçar por promover uma ampliação de alguma outra forma [grifo nosso]. (Breuer \& Freud, 1895/1987, p.263)

Freud, aos poucos, viria a abandonar as tentativas de provocar hipnose e se contentaria em levar as pacientes a um estado que chamou de "concentração", deitadas e de olhos fechados, com o uso ocasional da pressão de sua mão na testa delas. Em uma longa nota de rodapé, presente no relato de caso de Lucy R. dos Estudos sobre a histeria, Freud nos dá uma amostra explícita de sua forma de trabalhar naquele momento, nos casos em que não havia a possibilidade de se valer da hipnose. 
Tratava-se de uma paciente de 38 anos que sofria de neuroses de angústia. Freud relata que, a princípio, ela sabia apenas que o primeiro ataque de vertigem com angústia a acometera aos 17 anos enquanto estava fora, fazendo compras:

- "O que você queria comprar?" - "Coisas variadas, creio, para um baile para o qual me haviam convidado." - "Quando devia se realizar esse baile?" - "Pareceme que dois dias depois." - "Então algo deve ter acontecido, alguns dias antes, que a agitou, que a impressionou." - "Mas não sei de nada, isso faz 21 anos." "Não importa, você se lembrará mesmo assim. Farei uma pressão sobre sua cabeça e, quando abrandá-la, você pensará em algo ou verá alguma coisa, e em seguida me dirá." Realizo o procedimento; ela, porém, se cala. - "Então, nada lhe ocorreu?" - "Pensei em algo, mas não poder ter nenhuma ligação com isso." “Apenas diga o que foi." - "Pensei numa jovem amiga, uma garota que morreu; ela, porém, morreu quando eu tinha dezoito anos, ou seja, um ano depois." "Veremos; agora vamos nos deter nisso. Fale dessa amiga." - "Sua morte me abalou muito, pois nos víamos com frequência. Algumas semanas antes, outra garota havia morrido e isso causou sensação na cidade; sim, foi quando eu tinha dezessete anos." - "Você vê? Eu lhe disse, pode-se confiar nas coisas que ocorrem a alguém sob a pressão da mão. Agora você lembra que tipo de pensamento lhe ocorria quando teve o ataque de vertigem na rua?" - "Não havia pensamento algum, apenas vertigem.” - "Isso não é possível, tais estados não existem sem uma ideia que os acompanhem. Vou pressionar outra vez e o pensamento daquele instante ressurgirá. Então o que ocorreu?” - “Ocorreu-me: eu sou a terceira.” - “O que significa isso?" - "Devo ter pensado durante o ataque de vertigem: agora 
também vou morrer como as outras duas garotas." - "Esta era, pois, a ideia; durante o ataque, você pensou na sua amiga. Sua morte deve ter lhe causado uma grande impressão." - “Sim, certamente, agora me lembro; quando soube da morte, me pareceu terrível que eu devesse ir a um baile, enquanto ela estava morta. Mas ansiava tanto pelo baile e estava tão ocupada com o convite que não queria absolutamente pensar no triste acontecimento." ... Podemos agora reconstruir sem dificuldade a conexão entre os episódios e penetrar no mecanismo desse ataque histérico. É verdade que esse resultado foi obtido à custa de muito trabalho e exigiu total confiança na técnica, de minha parte, e a ocorrência de várias ideias condutoras. (Breuer \& Freud, 1895/2106, pp. 165-167)

A transcrição desse longo trecho se justifica na medida em que demonstra aspectos importantes do método de trabalho que Freud se valia quando a hipnose não era alcançável. Percebe-se que Freud seguia cada uma das "ideias condutoras", uma a uma, buscando identificar as ligações entre elas e passando para a seguinte; asseverava energicamente à paciente que as lembranças ocorreriam; obrigava-a a comunicar o que lhe viessem à mente após suas perguntas, repetindo o processo de pressão na testa tantas vezes quanto fossem necessárias; exibia uma confiança absoluta nessa técnica. Técnica que ele mesmo descreveu como, apesar de muito trabalhosa, eficaz.

Ao mesmo tempo, já se faz presente no relato uma convicção freudiana em um aspecto do funcionamento mental: nada era esquecido, todas as lembranças e impressões estavam de algum modo interligadas e atuantes no psiquismo. Era preciso proceder no tratamento a uma espécie de caminhada por essas ideias com a paciente, seguindo uma a uma, sem intentar ir direto ao ponto, abrindo mão de descobrir por uma via breve o 
“pensamento patológico". Ao exercer a pressão na testa, Freud convidava a paciente a se concentrar sobre a causa de seu sintoma. "Era um estado intermediário entre o diálogo e a hipnose. Os sintomas eram tratados um a um, em si mesmos, afrontados diretamente como problemas propostos" nos diz Lacan (1953/1986, p. 30).

Ao descrever sua confiança irrestrita nesse método, Freud demonstrava sua convicção que alguma associação entre conteúdos psíquicos era, de algum modo, sempre presente. A resistência à lembrança ou ao dizer significavam uma resistência à própria associação. Jorge (2017) nos diz que "surge assim, nesse ponto, um elo nítido entre resistência e insistência: se a resistência é sempre no fundo resistência à associação, a insistência do analista deve operar no sentido da insistência à associação" (Jorge, 2017, p. 50).

Já era, de alguma forma, uma técnica que partia de um pressuposto de que os conteúdos psíquicos eram dispostos em forma associativa. Seja lá qual fosse a imagem ou o pensamento que viesse à mente das pacientes após a pressão em suas cabeças, eles estariam de alguma forma vinculados à ideia buscada. Seguir - ou melhor, insistir em tal cadeia associativa de ideias - era o que o médico fazia. Freud diz que "o não saber dos histéricos era, pois, em verdade, um mais ou menos consciente não querer saber, e a tarefa do terapeuta consistia em vencer essa resistência à associação por meio de um trabalho psíquico" (Breuer \& Freud, 1895/2016, p. 379). O grifo anterior foi dado pelo próprio autor, o que demonstra como a noção de resistência surge para Freud pari passo à da característica associativa do psiquismo.

No entanto, o método da pressão na testa e da concentração, ainda que partisse de um pressuposto associativo da mente, não era de nenhuma maneira livre: Freud, de fato, exercia uma pressão, literal e metafórica: sua mão na testa, a atitude enérgica, a obrigação 
de lembrar, suas perguntas, o processo como um todo era descrito, pelo próprio autor, como bastante desgastante e trabalhoso. O que parecia estar em questão no retrato apresentado pelos relatos clínicos de Estudos sobre a histeria era a busca de Freud por uma técnica que fizesse o sujeito falar, ou melhor dizendo, lembrar associando. Freud usava, literalmente, o que tinha à mão. Improvisava. Contudo, segundo Gay (1988/2004), "ao abandonar gradualmente a hipnose, Freud não estava simplesmente fazendo da necessidade uma virtude; essa mudança, pelo contrário, levou a importantíssima adoção de um novo modo de tratamento. Formava-se a técnica da associação livre” (p. 81).

O caso de Elisabeth Von R., também descrito nos Estudos sobre a histeria, é bastante elucidativo sobre o processo de construção da técnica que Freud vinha empreendendo em seu método de tratamento. Elizabeth era uma jovem de 24 anos, sofrendo havia dois anos de dores nas pernas e dificuldade de andar. Ela fora encaminhada a Freud por um amigo médico. Freud descreve o tratamento de Elizabeth como sua primeira análise integral de um caso de histeria.

Cheguei a um procedimento que mais tarde elevei a método e empreguei deliberadamente, um procedimento de remoção do material psíquico patogênico por camadas, que gostávamos de comparar à técnica de escavação de uma cidade soterrada. Primeiramente fazia com que a doente me contasse o que sabia e reparava cuidadosamente onde uma conexão permanecia enigmática, onde parecia faltar um elo na cadeia causal ... O pressuposto de todo o trabalho era naturalmente a expectativa de que uma determinação perfeitamente suficiente se verificasse. (Breuer \& Freud, 1895/2106, p. 200) 
Freud fazia perguntas, incentivava Elisabeth a fazer associações, escavava seu discurso atento às conexões ausentes. Durante seus silêncios, ele lhe perguntava o que se passava em sua mente e não aceitava um "nada" como resposta. Para Jorge (2017), no caso de Elisabeth, já comparece, de modo eloquente, a visão freudiana do inconsciente como um saber, ao qual "o sujeito não tem acesso sem a experiência da análise e da regra da associação livre, através da qual esta opera, que modela toda a concepção freudiana da interpretação como uma intervenção recolhida das palavras mesmas do analisando" (Jorge, 2017, p. 43).

Freud notou que as pernas doloridas de Elisabeth começaram a "participar da conversa sempre" (Breuer \& Freud, 1895/2016, p. 213) voltando ou deixando de doer na medida em que as lembranças eram despertadas em sua fala. "Toda a cadeia de reminiscências devia evidenciar a justificada ligação entre as dores e o estar de pé e podia também ser considerada prova da associação" (Breuer \& Freud, 1895/2016, p. 216). Freud encontra tal associação ao ouvir um relato feito por Elisabeth de uma série de episódios com a queixa de que esses a fizeram sentir dolorosamente seu "estar só" ${ }^{4}$. Não cansando de repetir que o doloroso nisso era o seu sentimento de desamparo, a sensação de que "não saía do lugar". (Breuer \& Freud, 1895/2016, p. 216).

A ideia de que pensamentos dolorosos pudessem encontrar uma expressão simbólica por meio de sintomas somáticos já havia sido descrita por Freud antes, a novidade que parece se apresentar nesse momento era a de que essa simbolização poderia se dar através de uma expressão verbal, um jogo de palavras passível de ser escutado pelo médico com a paciente falando de forma livre, no modelo de uma conversa cotidiana.

\footnotetext{
$4 \quad$ No original, Alleinstehen, ser solteiro, sem família; composto de allein (sozinho) e stehen (estar, estar de pé, estar parado).
} 
Esse tipo de escuta do médico já não o tornava tão dependente da plena cooperação, inteligência e confiança da paciente, como exigia a hipnose. Elisabeth não sabia o que dizia enquanto falava, mas Freud a escutava para além do que julgava lhe contar. Além disso, se Freud já percebe que um sintoma pode ser construído ao se valer de um arranjo de palavras, parece existir nessa observação não apenas a força da linguagem para o adoecimento, mas a indicação de caminho que deveria ser percorrido no tratamento para sua cura.

Freud, em um belo trecho, que peço licença para transcrever aqui na íntegra, se mostra especialmente ilustrativo deste momento de gestação da técnica da livre associação, bem como dos mecanismos e modos de sua eficácia que gradativamente descobria e que o levariam a nomeá-la como regra fundamental da Psicanálise. Freud ouvia Elisabeth, o assunto girava em torno dos eventos relacionados ao momento de morte da irmã:

Há muito tempo ficara claro para mim do que se tratava. A doente, imersa em recordações doce-amargas, parecia não perceber para que explicação se encaminhava e prosseguia na reprodução de suas reminiscências. Veio o tempo em Gastein, a aflição com que ela aguardava cada carta, finalmente a notícia de que a irmã estava mal, a longa espera até o anoitecer, quando puderam partir de Gastein, a viagem em torturante incerteza, em noite insone - todos esses momentos que foram acompanhados por forte aumento das dores. Perguntei-lhe se durante a viagem havia imaginado a triste possibilidade que em seguida encontrou consumada. Ela respondeu que evitara cuidadosamente esse pensamento, mas a mãe, em sua opinião, desde o início havia esperado o pior. 
Seguiu-se então sua lembrança da chegada a Viena, das impressões que recebera dos parentes que as esperavam, da curta viagem de Viena à instancia de verão próxima, onde a irmã morava, da chegada ali ao anoitecer, do caminho apressadamente transposto, pelo jardim, até a porta do pequeno pavilhão - o silêncio na casa, a escuridão opressiva; o cunhado que não as recebeu; depois ficaram de pé diante do leito, viram a morta e, no momento de horrível certeza de que a irmã amada havia morrido sem se despedir delas, sem ter seus últimos dias confortados pelos seus cuidados - no mesmo momento, um outro pensamento atravessara de súbito o cérebro de Elisabeth, um outro pensamento que agora, incontestavelmente, de novo se apresentava, o pensamento que, como um raio fulgurante, disparou através da escuridão: ‘Agora ele está livre outra vez e posso me tornar sua mulher'. Assim, pois, tudo estava claro. (Breuer \& Freud, 1895/2016, p. 225).

Freud descreve - no modelo de uma novela, uma cena, um sonho - o caminho associativo percorrido por Elisabeth nesse momento. Ele o faz em detalhes, descrevendo de que modo sua paciente passou por cada pensamento, sensação e lembrança enquanto lhe falava. Logo no começo de seu relato, Freud nos conta que já o sabia há muito, mas se cala, deixa Elisabeth falar. Nesse momento, Freud não interpreta, deixa a cadeia de associações se desenrolar livremente, faz apenas uma única pergunta para que Elisabeth dê prosseguimento a suas associações e é ela quem encontra, como a um raio na escuridão, o pensamento sobre seu cunhado agora ser um homem livre.

Segundo Freud, o efeito da "readmissão" daquela ideia reprimida foi devastador para Elisabeth. "Lançou um sonoro grito quando resumi os fatos com essas palavras 
secas: 'Há muito tempo, então, você estava enamorada de seu cunhado" (Breuer \& Freud, 1895/2016, p. 226). Nesse momento, a paciente se queixou de dores nas pernas e rejeitou a explicação, dizendo que Freud a havia persuadido daquilo. Os argumentos de consolo moral de nada adiantaram, nos conta Freud e completa que "nesse momento, precisava seguir mais que um só caminho para proporcionar alívio a doente" (Breuer \& Freud, 1895/2016, p. 227).

Freud descreve então o procedimento adotado com Elisabeth: resolve investigar todas as primeiras impressões dela com seu cunhado, encontrando cada pequeno indício e pressentimentos de uma paixão, "ao percorrermos essas reminiscências, tornou-se claro para Elisabeth que o terno sentimento por seu cunhado estava adormecido havia muito tempo, talvez desde o início de suas relações ... Essa ab-reação com certeza lhe fez muito bem" (Breuer \& Freud, 1895/2016, p. 228).

O que Freud descreve nesse momento com uma ab-reação promovida pelo método catártico parece ser menos o despertar na consciência do afeto doloroso propriamente dito, "o raio fulgurante", e muito mais o resultado dos diversos caminhos associativos que o autor nos conta que precisou seguir com Elisabeth no momento posterior. Freud, ao "percorrer essas reminiscências", promove novas e mais associações, aumenta a cadeia associativa ligada ao insight e, apenas desse modo, cessam as dores de Elisabeth, ele a "convence" do amor pelo cunhado. Freud leva sua paciente associar e, nesse processo, a paciente elabora suas lembranças e se convence do que havia dito.

Portanto, a cura de Elisabeth não se circunscrevia ao desafogar da emoção penosa represada ao reviver o afeto estrangulado, mas na possibilidade de colocar em marcha um processo de trânsito psíquico e de elaboração promovidos pela fala associativa da paciente. Esse tipo de fala, Freud percebe ainda que sem teorizar a respeito, elaborava. 
Laplanche e Pontalis (1967/2004) consideram que "Freud descreve, às vezes, como um processo de ab-reação um verdadeiro trabalho de rememoração e de elaboração psíquica, em que o mesmo afeto se acha reavivado correlativamente à recordação dos diferentes acontecimentos que o suscitaram" (p. 2). Na discussão do caso de Elisabeth, Freud parece corroborar tal visão quando afirma que, com relação ao amor pelo cunhado, a paciente ocupava um estado de saber e não saber ao mesmo tempo, "não queremos dizer que se trata de uma qualidade inferior ou um grau menor de consciência, mas sim de uma separação entre o livre trânsito associativo de pensamentos e o conteúdo ideativo restante" (Breuer \& Freud, 1895/2016, p. 238).

Após o momento descrito, Freud considera Elisabeth curada e dá por encerrado seu tratamento. Algumas semanas depois, recebe uma carta da mãe da paciente contando que Elisabeth voltara a sentir dores nas pernas e estava furiosa com Freud. Contudo, Freud diz manter uma certeza de que seu esforço não havia sido em vão e que tudo se resolveria com o tempo. Não sem ironia, nos conta que, algum tempo depois, recebeu um convite para uma festa em que Elisabeth estaria presente e "não deixei escapar a oportunidade de ver minha antiga doente passando a voar numa dança célere” (Breuer \& Freud, 1895/2016, p. 231).

Gay (1988/2004) nos relata que Elisabeth, em conversa com sua filha, não reconheceu que Freud tivesse resolvido seus sintomas neuróticos, ela o descreveu como “apenas um jovem especialista de nervos, com barba, ao qual me mandaram. Ele havia tentado me convencer de que eu estava apaixonada pelo meu cunhado, mas não era realmente isso" (p.82). ${ }^{5}$

\footnotetext{
$5 \quad$ O mecanismo da negativa (Verneinung) ainda demoraria a se tornar uma realidade teórica, mas é, no mínimo, curiosa a forma como Gay (1988/2004) relata ter Elisabeth escolhido suas palavras para se remeter ao tratamento com Freud.
} 
Contudo, Elisabeth se casara novamente e estava feliz. Gay (1988/2004) acrescenta que a paciente pode ter decidido, de modo mais ou menos consciente, reprimir a interpretação de seus problemas feita por Freud, "ou Freud pode ter lido paixões inaceitáveis em seu fluxo de eloquência livre e desinibido. De qualquer forma, aí estava ... uma histérica que frequentemente sofria de sérias dores nas pernas ... a dançar noite adentro" (p.82). Ou seja, como previra Freud, sua análise havia tido algum êxito, e não fazia a menor diferença que Elisabeth não estivesse convencida de seu antigo e proibido amor pelo ex-cunhado, foram outros os passos que a permitiram dançar.

Se os estudos teóricos anteriores, como em Sobre a Concepção das Afasias, foram um ensaio das reflexões de Freud sobre o funcionamento mental, os Estudos sobre a Histeria foi o grande laboratório freudiano para seu método de tratamento. Nascida prematura, a técnica foi passando por ajustes, reformulações e adaptações. Mas foi no tratamento da histeria que o método floresceu e a técnica da livre associação foi aos poucos se impondo para Freud, a um só tempo, sendo descoberta e inventada.

Strachey, em suas considerações ao texto de Freud sobre a histeria, nos diz que: "Nos anos que se seguiram aos Estudos, Freud abandonou cada vez mais a técnica da sugestão deliberada e passou cada vez mais a confiar no fluxo de 'associações livres' do paciente. Estava aberto o caminho para a análise dos sonhos" (Strachey in Breuer \& Freud, 1895/1987, p.24). 


\section{Capítulo 2}

\section{Da associação livre à regra fundamental - o método de tratamento}

Though this be madness, yet there is method in 't

William Shakespeare, Hamlet

\subsection{O método psicanalítico de Freud}

Em Contribuição à História do Movimento Psicanalítico, de 1914, Freud indica que "a história da psicanálise propriamente se inicia apenas com a inovação técnica da renúncia à hipnose” (Freud, 1914/2012, p. 258). Mais adiante, acrescenta: “A respeito da interpretação dos sonhos não preciso dizer muito. Ela me veio como o primeiro fruto da inovação técnica, depois que resolvi, seguindo um vago pressentimento, trocar a hipnose pela associação livre" (Freud, 1914/2012, p. 262). Se o abandono técnico da hipnose inaugurou a história da psicanálise propriamente dita, a adoção da técnica da associação livre no contexto do tratamento teve a consequência de levar Freud a se ocupar dos sonhos.

O final do século XIX encontrou um Freud solitário e desanimado diante das dificuldades das inúmeras tarefas que se apresentavam:

A interpretação dos sonhos tornou-se consolo e suporte para mim nos difíceis primeiros anos da psicanálise, quando tinha que dominar simultaneamente a 
técnica, a clínica e a terapia das neuroses; achava-me inteiramente só e muitas vezes temia perder a orientação e a confiança em meio a problemas e dificuldades que se acumulavam. A comprovação de minha premissa de que uma neurose se torna compreensível mediante a análise demorava frequentemente de forma desconcertante nos doentes; já nos sonhos, que podiam ser vistos como análogos aos sintomas, tal premissa achava uma confirmação quase regular. (Freud, $1914 / 2012$, p. 263)

O interesse que os sonhos despertavam nas reflexões de Freud já foi apontado aqui, no primeiro de seus casos apresentado nos Estudos sobre a histeria, da sra. Emmy Von $\mathrm{N}$, em que ele vincula os sonhos à noção de "compulsão à associação". A própria semelhança de estrutura entre os sonhos e os sintomas neuróticos já havia sido notada por Freud no Projeto para uma Psicologia Científica, que era esboçado em 1895, no qual Freud dedica aos sonhos três pequenos capítulos na Parte 1.

Nesses capítulos, Freud já notava que "os mecanismos patológicos revelados nas psiconeuroses pela análise mais cuidadosa guardam uma grande semelhança com os processos oníricos" (Freud, 1895/1987, p. 352). Além disso, percebe que nos sonhos as conexões absurdas, sem sentido, se explicam pelo fato de que neles "predomina a compulsão a associar, que sem dúvida também domina primordialmente a vida psíquica em geral" (Freud, 1895/1987, p. 355). As ideias oníricas são de caráter alucinatório, despertam à consciência e recebem crédito, essa é a característica mais importante do sono. "A pessoa fecha os olhos e alucina, torna a abri-los e pensa com palavras". (Freud, 1895/1987, p. 355). Sobre essa correlação entre sonho e vigília, Freud (1895/1987) é 
ainda mais específico ao abordar a questão da consciência das ideias oníricas, frisando sua descontinuidade:

O que se torna consciente não é uma sucessão integral de associações, mas apenas alguns de seus pontos de parada isolados. Entre os quais existem vínculos intermediários inconscientes que podemos facilmente descobrir quando estamos acordados... O enigma dos vínculos intermediários inconscientes se aplica também ao pensamento desperto, no qual eventos semelhantes são uma ocorrência cotidiana. (Freud, 1895/1987, pp. 357-358)

Portanto, se os mecanismos patológicos das psiconeuroses tinham semelhança com a formação onírica, se os sonhos estavam sujeitos à “compulsão à associação" tanto quanto a vida psíquica em geral e se os sonhos transformavam pensamentos em alucinações que deixavam rastros de associações (vínculos intermediários inconscientes) tanto quanto na vida desperta, parecia haver inúmeras razões para Freud se ocupar dos sonhos. Especialmente em um momento em que, segundo o próprio Freud, os tratamentos que tentava levar a termo não pareciam funcionar tão bem como ele esperava.

O livro A interpretação dos sonhos, de 1900, seria um passo decisivo tanto para a construção da metapsicologia freudiana, quanto de um método próprio à psicanálise, diferente do método catártico de Breuer. Após as experiências de tratamento descritas em Estudos sobre a histeria, a tarefa que Freud parecia estar propondo a si mesmo com a escrita do livro é enunciada logo no prefácio à primeira edição: "quem quer que tenha falhado em explicar a origem das imagens oníricas dificilmente poderá esperar compreender as fobias, obsessões ou delírios, ou fazer com que uma influência 
terapêutica se faça sentir sobre eles" (Freud, 1900/1987, p.29). Explicar e compreender para poder tratar. O livro sobre os sonhos parecia, portanto, se apresentar para Freud como uma investigação, um projeto de pesquisa preliminar à construção de um método de tratamento que funcionasse a contento: "é minha intenção utilizar minha atual elucidação dos sonhos como um passo preliminar no sentido de resolver os problemas mais difíceis da psicologia das neuroses" (Freud, 1900/1987, p.126).

Na escolha do próprio título para sua obra, Die Traumdeutung ${ }^{6}$, Freud já deixava clara a abordagem que pretendia seguir. Freud (1900/1987) nos conta que interpretar um sonho seria atribuir-lhe um sentido, "isto é, substituí-lo por algo que se ajuste à cadeia de nossos atos mentais como um elo dotado de vitalidade e importância iguais ao restante" (p. 119). Desse modo, Freud parece dizer que, para ele, interpretar um sonho era algo mais que atribuir-lhe um sentido, mas produzir algo que, ao ser alcançado, se combinaria à cadeia associativa dos demais atos mentais do sonhador, formando uma conexão substancial e significativa com os demais pensamentos. Era isso o que a interpretação de um sonho deveria alcançar.

No segundo capítulo de A interpretação dos sonhos, intitulado "O método de interpretação dos sonhos: análise de um sonho modelo", Freud vai descrever sua técnica de interpretação dos sonhos. Antes, ele a diferencia das técnicas mais usuais nos estudos precedentes sobre os sonhos. A primeira, a interpretação simbólica, considerava o conteúdo do sonho como um todo único e procurava substitui-lo por outro que fosse inteligível (como no sonho do Faraó feito por José na Bíblia); essa falharia ao encontrar

$6 \quad$ O título em alemão, segundo Dra. Vera Ribeiro, revisora da 2o edição das Obras Completas, não expressa uma ideia de interpretação fechada ou final dos sonhos, mas de um processo de busca do sentido dos sonhos para cada sujeito singular. Tratando os sonhos como produções psíquicas que eram um efeito desse sentido. "Para o leitor de língua alemã, essa postura freudiana ficava clara já no título da obra" (N. da Rev. Geral, p.119). 
sonhos confusos ou ininteligíveis. A segunda, chamada por Freud de "o método da decifração", trata o sonho como uma espécie de criptografia, em que cada signo do sonho pode ser traduzido por outro signo de significado conhecido. À diferença do primeiro, o método da decifração teria a vantagem de não ser aplicado ao sonho como um todo, mas a cada uma de suas partes em separado. No entanto, nessa técnica a decifração dependia sempre da confiabilidade de um código fixo estabelecido pelo intérprete.

Freud (1900/1987), em uma nota de rodapé acrescentada em 1914, afirma que a técnica que descreve naquele momento difere do método da decifração "num ponto essencial: ele impõe a tarefa de interpretação à própria pessoa que sonha. Não se interessa pelo que ocorre ao intérprete em relação a um elemento específico do sonho, mas pelo que ocorre ao sonhador" (p. 121). Assim, a técnica de interpretação exposta na Die Traumdeutung não era a simbólica, tampouco a de decifração, ainda que se aproximasse de alguma forma desta última. Continha, em sua essência, algo diferente e Freud não esconde sua origem:

Meu conhecimento desse método foi obtido da seguinte maneira. Tenho-me empenhado há muitos anos (com o objetivo terapêutico em vista) em deslindar certas estruturas patológicas ... no tocante a essas estruturas (que são consideradas como sintomas patológicos), sua decomposição [Auflosung] coincide com sua solução [Losung].” (Freud, 1900/1987, p.123)

Note-se que Freud, ao retomar uma das teses centrais de Estudos sobre a histeria nesse momento, não afirma que a solução do sintoma patológico viria após sua decomposição, mas que justamente coincidiria com ela. Na própria escolha homofônica 
das palavras em alemão, Freud parece indicar que esses dois momentos estariam, de alguma forma, sobrepostos. Ele é ainda mais explícito no trecho seguinte: "Quando esse tipo de representação patológica pode ser rastreado até os elementos da vida mental do paciente dos quais se originou, a representação ao mesmo tempo [grifo nosso] se desarticula, e o paciente fica livre dela" (Freud, 1900/1987, p. 123).

Freud (1900/1987) se remete ao tratamento da histeria como a origem de seu interesse pelos sonhos e nos diz que "faltava então apenas um pequeno passo para se tratar o próprio sonho como um sintoma e aplicar aos sonhos o método de intepretação que fora elaborado para os sintomas" (p.123). Esse "pequeno passo" é dado ao se adotar a técnica livre-associativa como o núcleo do método para interpretar os sonhos:

Nosso primeiro passo no emprego desse método nos ensina que o que devemos tomar como objeto da nossa atenção não é o sonho como um todo, mas partes separadas de seu conteúdo. Quando digo ao paciente ainda novato: 'que é que lhe ocorre em relação a esse sonho?', seu horizonte mental costuma transformar-se num vazio. No entanto, se colocar diante dele o sonho fracionado, ele me dará uma série de associações para cada fração, que poderiam ser descritas como 'pensamentos de fundo' dessa parte específica do sonho. (Freud, 1900/1987, p.125)

Podemos depreender, aqui, que esse passo freudiano é sobremaneira tributário de sua experiência dos tratamentos da histeria descrito em nosso capítulo anterior. Foi no tratamento das histéricas, dentro de sua prática cotidiana, que a associação livre, de várias maneiras, se impôs para Freud. Em 1900, no seu estudo sobre os sonhos, ela não é mais 
incidental, Freud se apropria da associação livre como técnica e a adota efetivamente como ferramenta essencial de seu método de interpretação dos sonhos. Sem associação livre não havia interpretação dos sonhos possível para Freud. Ademais, é por meio da interpretação dos sonhos, ou seja, da técnica livre-associativa, que Freud alcança e estrutura sua teoria do aparelho psíquico nesse momento de criação da psicanálise. Como bem lembra Bollas (2005), Freud nunca se furtou em admitir que foram seus pacientes que lhe ajudaram a descobrir seu método.

Voltemos ao método de interpretação para descrevê-lo. Freud fraciona o sonho e pede ao sujeito que associe sobre cada uma dessas partes, abandonando sua função crítica em relação aos pensamentos que lhe ocorrem, bem como aumentando a atenção que dispensa à observação de seus próprios processos psíquicos. Nos dizeres de Mezan (1998), “a associação parte de cada fragmento do sonho porque este é concebido como um nó de significações, produzido pela operação conjunta da condensação, do deslocamento, da consideração pela representabilidade e da elaboração secundária sobre a 'matéria-prima' do sonho" (p.84).

Perceba-se que, ao contrário do tratamento da histeria, para Freud já não havia um caminho alternativo (hipnose, pressão na testa), seria apenas por meio desse processo de associação livre que um sonho poderia ser adequadamente interpretado - ou seja, dotado de vitalidade e inserido em uma cadeia de sentido como os demais atos mentais. Ainda que não o nomeie nesses termos, a técnica que Freud assumia como efetiva para interpretar sonhos era a livre-associativa. Parece ser esse o momento do pensamento freudiano em que a associação livre vai ganhando o status de regra fundamental do método. Freud o demonstra com a análise de seu próprio sonho, o notório "sonho da injeção de Irma". 
Freud (1900/1987), em sua descrição da análise desse sonho modelo, o "quebra" em inúmeros fragmentos e apresenta de modo pormenorizado suas associações para cada um deles. Identifica ligações entre elementos, superposições de pensamentos, inversões de sentido, apresenta as mais distantes recordações evocadas por cada fragmento singular. Em suma, Freud tenta percorrer toda a extensão das cadeias de pensamentos que a análise do sonho apontava em cada associação, demonstrando que os elementos presentes no sonho remetiam tanto aos restos de pensamento do dia anterior quanto a fatos ocorridos muitos anos antes e que se ramificavam até o limite do insondável, a "um umbigo, por assim dizer, que é seu ponto de contato com o desconhecido" (p.132).

Nesse processo de descrição da análise do sonho de Irma, Freud apresenta ao leitor a importância de cada detalhe presente no sonho, do uso peculiar das palavras e imagens, o caminho tortuoso de idas e vindas que cada fragmento lhe obrigava a percorrer. Ao se fiar na técnica livre-associativa, Freud não se furta à exposição de sua intimidade na análise desse sonho, apresenta suas culpas, recriminações, ânsias de vingança, seu desejo sexual inconfesso, para, enfim, deslindar o sentido do sonho, não sem apontar a dificuldade inerente à técnica empregada:

Acabo de concluir a interpretação do sonho. Enquanto a efetuava, tive certa dificuldade em manter à distância todas as ideias que estavam fadadas a ser provocadas pela comparação entre o conteúdo do sonho e os pensamentos ocultos por trás dele. Entrementes, compreendi o 'sentido do sonho'... seu conteúdo foi a realização de um desejo, e seu motivo foi um desejo. (Freud, 1900/1987, p.138) 
Mezan (1998) aponta que o estudo dos sonhos oferecia sobre a neurose duas vantagens decisivas para que Freud se valesse deles como instrumento de investigação do aparelho psíquico: era incomparavelmente mais simples e ocorria a todos os sujeitos.

O que a Interpretação dos Sonhos traz de novo é o estatuto minucioso dos mecanismos de deformação, chamados de 'trabalho do sonho', e uma teoria abrangente do aparelho psíquico, capaz de dar conta da possibilidade desse trabalho. A importância desta investigação para a remodelação da teoria das neuroses, num registro propriamente psicológico, e para a elucidação do problema da repressão, cuja atividade é fácil de perceber por trás da deformação onírica, não precisa ser ressaltada. (Mezan, 1998, p.77)

Um trecho da discussão sobre o esquecimento dos sonhos, trazida por Freud no capítulo VII da Die Traumdeutung, parece significativo para entendermos a legitimação da associação livre como regra fundamental do tratamento psicanalítico. Freud admite serem pertinentes as críticas de vários autores de que os sonhos, ao serem contados, são distorcidos pelo discurso do sonhador. Contudo, tal distorção não é mais que um segundo processo de deformação pelo qual passa o material inconsciente, nos diz Freud, tendo em vista que o próprio sonho já seria uma primeira distorção dos pensamentos latentes. Nesse ponto ele acrescenta:

O único erro cometido pelos autores precedentes foi supor que a modificação do sonho, no processo de ser lembrado e posto em palavras, é arbitrária e não admite maior análise, sendo, portanto, passível de nos fornecer uma imagem enganosa do 
sonho. Eles subestimaram a extensão do determinismo nos eventos psíquicos. Não há neles nada de arbitrário... Por exemplo, posso tentar pensar arbitrariamente num número, mas isso é impossível: o número que me ocorre é inequívoca e necessariamente determinado por pensamentos que haja em mim, ainda que estejam distantes da minha intenção imediata. Do mesmo modo, as modificações a que os sonhos são submetidos na redação da vida de vigília tampouco são arbitrárias. Estão associativamente ligadas ao material que substituem. (Freud, 1900/1987, p. 473)

Ora, Freud nos diz saber que a fala de qualquer sujeito, até quando tenta ser livre, é determinada, psiquicamente determinada e vinculada de forma indissociável às associações que tomam seu lugar. Se é possível distorcer conteúdos psíquicos, seria impossível, para Freud, tê-los completamente apartados de todos os outros. Logo, o discurso em livre-associação do sujeito, tomado como regra fundamental do tratamento psicanalítico, seria livre apenas na aparência. Como nos lembra Garcia-Roza (1988):

Quando Freud estabelece como regra fundamental da situação analítica a associação livre, ele não pretende que o "livre" signifique ausência de determinação. Pelo contrário, o valor metodológico da associação livre reside exatamente no fato de que ela nunca é livre. É na medida em que o paciente fica livre do controle consciente (dentro dos limites possíveis), não permitindo que a coerência lógica se imponha ao seu relato, que uma outra determinação se torna possível: a do inconsciente. A associação livre não tem por objetivo substituir o 
determinado pelo indeterminado, mas substituir uma determinação por outra. (Garcia-Roza, 1988, p.171)

O que se insinua aqui é o conceito de sobredeterminação, presente não apenas nos sintomas, mas no discurso do sujeito em associação livre. Para Laplanche e Pontalis (1967/2004), é o estudo do sonho que mais claramente ilustra esse fenômeno da sobredeterminação para Freud, "as diversas cadeias significativas se entrecruzam em mais de um 'ponto nodal' como provam as associações" (p.488).

Como aponta Jorge (2008), apesar da tese do determinismo psíquico ter sido mais amplamente exposta no capítulo final de A psicopatologia da vida cotidiana, em que todos os atos, vontades, ditos, tendências dos sujeitos são determinados inconscientemente, a categoria freudiana da sobredeterminação evidenciava a primazia do simbólico na constituição do sujeito e fiava-se precisamente no fato de que "associação produzida pelo sujeito em análise não é nada livre, mas ao contrário, sobejamente determinada" (p.68). Lacan (1998), em seu texto Função e campo da fala e da linguagem em psicanálise, acentua ainda mais o papel da regra fundamental como ferramenta essencial do tratamento quando escreve sobre Freud:

Se ele nos ensinou a acompanhar, no texto das associações livres, a ramificação ascendente dessa linhagem simbólica, para nela detectar, nos pontos em que as formas verbais se cruzam novamente, os nós de sua estrutura, já está perfeitamente claro que o sintoma se resolve por inteiro numa análise linguajeira, por ser ele mesmo estruturado como uma linguagem, por ser a linguagem cuja fala deve ser libertada." (Lacan, 1998, p.270) 
Se Estudos sobre a histeria pode ser lido como uma tentativa de achar um meio de tratamento das histerias, A Interpretação dos Sonhos se aproxima de uma busca freudiana para a construção de sua metapsicologia, um processo de investigação que leva à criação de uma teoria do psiquismo. O que estava em jogo para Freud era o estabelecimento de uma espécie de geografia da mente. Se no primeiro já existia um esboço de uma teoria do psiquismo, o segundo serve a Freud para arrematar esse esboço e extrair dele o que embasaria seu novo método de tratamento.

É em A Interpretação dos Sonhos que a técnica livre associativa se consolida como regra fundamental do tratamento psicanalítico para Freud, regendo sua teorização do psiquismo e a construção de sua metapsicologia. Já que os sonhos eram a via régia para o inconsciente (Freud, 1900/1987, p.550), e seu método de interpretação se fundava na técnica da associação livre, é por esse caminho que o tratamento vai se dar. Contudo, antes foi preciso definir o método psicanalítico para além do contexto dos sonhos.

Em novembro de 1903, em contribuição ao livro de Leopold Loewenfeld intitulado Os fenômenos compulsivos psíquicos, Freud escreve, em terceira pessoa, um pequeno artigo: $O$ método psicanalítico freudiano, publicado em 1904. Como indicam Iannini e Tavares (2017), ao longo da década de 1890 a técnica freudiana havia sofrido diversas modificações e Freud viu no convite de Loewenfeld uma oportunidade para recensear tais modificações posteriores ao Estudos sobre Histeria em um momento em que o tratamento analítico já havia começado a se instituir internacionalmente. "Esse artigo pode ser lido como a primeira exposição abrangente acerca de técnica psicanalítica, em sua especificidade não apenas em relação à sugestão e à hipnose, que já não empregava há algum tempo, mas ainda ao método catártico" (p.59). 
Freud (1904/2017) constrói esse texto em uma sequência sugestiva. Primeiro assume que seu método "peculiar" de psicoterapia tem origem no processo catártico de Breuer. Descreve toda a dinâmica de funcionamento desse e acrescenta que nele o "esquema simples de intervenção terapêutica, no entanto, começou a se complicar quando ficou evidente que não era uma impressão única (traumática), mas geralmente uma 'série' dessas impressões, difíceis de serem superadas, que participavam do surgimento dos sintomas" (p.52). Apontando onde falhava o tratamento pelo método de Breuer, Freud começa a apresentar o novo método: “as mudanças que Freud fez no procedimento catártico de Breuer incialmente eram mudanças técnicas; mas estas precisavam de novos resultados e acabaram, na sequência, por mostrar a premência de uma concepção de trabalho terapêutico de outro tipo" (p.52).

Freud aponta, desse modo, que as mudanças técnicas, feitas onde falhava o tratamento no processo catártico, criaram o que havia de peculiar em seu método terapêutico. Começa por nos contar que nessas mudanças técnicas "evita qualquer contato e todo procedimento que possa lembrar a hipnose" (Freud, 1904/2017, p.53), deixando os doentes se posicionarem confortáveis no divã, fora do escopo visual, não exigindo que fechem seus olhos, "uma sessão assim transcorre como uma conversa entre duas pessoas igualmente despertas" (p.53).

Ao frisar a ausência da hipnose como uma marca distintiva de sua técnica, Freud (1904/2017) finalmente apresenta a essência de seu novo método:

Se não se criasse um substituto para essa ausência, não haveria como falar de uma intervenção terapêutica eficaz. Freud, então, encontrou um tal substituto plenamente suficiente nas ocorrências [Einfalle] dos doentes, isto é, naquelas 
ocorrências involuntárias, geralmente sentidas como pensamentos que atrapalham e que, por isso, sob condições normais seriam afastados, pois costumam atravessar o contexto de uma apresentação intencionada. (Freud, 1904/2017, p.53)

Eis, portanto, a primeira descrição feita por Freud da regra técnica fundamental do novo método, no contexto específico do tratamento (uma terapêutica eficaz). Ele a constrói, como indica a articulação de seus argumentos, na sua diferença para com o procedimento anterior, localizando na adoção da associação livre o diferencial técnico essencial que singulariza seu método do de Breuer. Chama a atenção que Freud opta, nesse momento, por apenas descrever a regra. Não a batiza como fundamental ou mesmo define algum outro termo para nomeá-la, unicamente descreve seu funcionamento. Já que, nesse mesmo texto, Freud não se furta a conceituar recalque, resistência, arte da interpretação e o tratamento; há, nesse caminho escolhido, algo que parece apontar para a singularidade dessa técnica dentro do método psicanalítico que estava sendo definido.

Ressaltam Iannini e Tavares (2017) que Freud usa em sua descrição o verbo einfallen: 'derivado de fallen, 'cair', para se referir àquilo que vem à tona, que não mais é retido, quando o analisante se entrega à associação livre. Os resultados dessas associações são Einfalle: 'aquilo que ocorre', numa palavra, as ‘ocorrências'” (pp. 9-10). Freud não utiliza, neste artigo de 1904, o conceito de associação [Assoziation]. Laplanche e Pontalis (1967/2004) lembram da força da doutrina associacionista na Alemanha do século XIX e sua influência sobre o jovem Freud. No entanto, apontam que ela foi integrada e transformada pela descoberta freudiana das leis do inconsciente. Em Psicanálise, 
Decididamente, o discurso associativo não é regido passivamente por leis gerais como as que o associativismo definiu: o sujeito não é um 'polipeiro' de imagens. O agrupamento das associações, seu isolamento eventual, suas 'falsas conexões', sua possibilidade de acesso à consciência, inscrevem-se na dinâmica do conflito defensivo próprio de cada um. (Laplanche \& Pontalis, 1967/2004, p. 37)

A propósito do emprego do termo Einfall, "literalmente o que cai no espírito, o que vem ao espírito ... convém diferenciar de Assoziation” (Laplanche \& Pontalis, 1967/2004, p. 439). O termo associação pode referir-se tanto a elementos tomados numa cadeia do discurso lógico, quanto às chamadas associações livres que, como apontamos anteriormente, Freud já sabia serem sempre determinadas. Einfall remeteria o conjunto de todas as ideias que ocorrem ao sujeito no decorrer das sessões, mesmo que a ligação associativa que as suporta não seja aparente ou que subjetivamente se apresentem como desligadas do contexto. Definido a partir do termo Einfall o efeito da regra fundamental “não é dar livre curso ao processo primário puro e simples, abrindo assim acesso imediato às cadeias associativas inconscientes, apenas favorece a emergência de um tipo de comunicação em que o determinismo inconsciente é mais acessível" (Laplanche \& Pontalis, 1967/2004, p. 439).

Ou seja, a descoberta psicanalítica dos processos inconscientes empreendida por Freud no livro dos sonhos, apesar de ser tributária da técnica da associação livre, parece dar um novo sentido aos pressupostos associacionistas em que Freud se apoiava. Não é escopo deste trabalho adentrar mais a fundo nessa discussão, mas apenas indicar que Freud, no modo como descreve sua técnica livre-associativa, parece apontar que se trata de algo diferente e específico. Voltemos, portanto, à descrição freudiana em $O$ método 
psicanalítico freudiano, no trecho imediatamente subsequente ao anteriormente transcrito, para tentar entender do que se trata:

Para se apoderar dessas ocorrências, ele convida os doentes a falarem à vontade em suas comunicações, 'como, por exemplo, em uma conversa na qual um assunto se passa a outro totalmente diferente [aus dem Hundertsten ins Tausendste kommen]' Antes de convidá-los à narrativa detalhada do histórico de sua doença, ele reforça a instrução de que eles lhe contem tudo que lhe vem à cabeça, mesmo se acharem não ser importante, ou se acharem que aquilo não vem ao caso, ou que não faz sentido. Mas com bastante ênfase exige deles que não excluam nenhum pensamento ou nenhuma ocorrência da comunicação pelo fato de lhes parecer vergonhoso ou embaraçoso. (Freud, 1904/2017, pp. 53-54).

A tradutora da referida obra para o português, Claudia Dornbusch, nos informa que a expressão original em alemão "aus dem Hundertsten ins Tausendste kommen" significa, literalmente: sair de um centésimo e chegar a um milionésimo. "Querendo dizer que uma coisa leva a outra, um assunto leva a mil outros, e se perde o fio da meada, esquecendo-se de buscá-lo, já que se trata de conversa informal e não há necessidade de coerência absoluta” (N.T., Freud, 1904/2017, p.60).

O que Freud parece aludir ao usar essa expressão idiomática é ao tipo de estado de espírito que a regra técnica buscaria alcançar no contexto terapêutico. Como dito em uma ironia fina e certeira por Nosek (2015) "Se a psicanálise tivesse se originado no interior do Brasil e não no Império Austro-Húngaro, talvez usássemos a expressão ‘jogar conversa fora' ou 'picar couve', ou qualquer outra que sugerisse coloquialidade, e não 
mistério para iniciados" (p.19). A regra técnica da associação livre, no formato descrito por Freud no texto de 1904, propõe instaurar um tipo de diálogo que se afasta não apenas do da hipnose, mas de qualquer outro tipo de relação tradicional.

Lysy-Stevens (2000) comenta que Freud "convida os doentes a serem displicentes, como numa conversação atabalhoada" (p.18) para propiciar um encontro singular que a autora nomeia como A sessão freudiana, "o diálogo da sessão é inédito, há uma lógica própria que não é da conversação corrente nem a da consulta médica” (p.19). Se como nos lembra Lacan (1953/1986) a lei da conversa comum é a interrupção, o dispositivo analítico criado por Freud instaura uma situação nova, em que o sujeito não é mais interrompido em suas ocorrências, "o discurso, desligado de um certo número de suas convenções pela regra dita fundamental, põe-se a jogar mais ou menos livremente em relação ao discurso ordinário, e abre o sujeito a essa equivocação fecunda” (p.322).

Assim, a associação livre que propicia a sessão freudiana nos parece em substância, bastante afastada do método da escrita livre de Ludwig Borne, que Freud admitiu ser uma influência em Contribuição à pré-história da técnica psicanalítica de 1920. Mannoni (1992) parece ter captado a singularidade da proposta freudiana quando nos diz que não se deve depreender da regra algo como uma imposição para que se faça associações absurdas, "a regra seria antes esta: se uma associação lhe parece absurda e mesmo assim se impõe [grifo do autor], não a rejeite como absurda" (p.79).

Freud, portanto, convidava seus pacientes a não se oporem a seja lá o que lhes ocorresse durante sua fala, que se deixassem levar pelo que diziam. Em sua adoção como técnica do tratamento em oposição à hipnose, o que a regra fundamental parece instituir é uma situação singular que existiria apenas dentro do método freudiano - em outras palavras, é como se Freud dissesse: é assim a conversa no tratamento psicanalítico. Pois, 
“nessa relação das ocorrências involuntárias com o material recalcado reside, então, o seu valor para a técnica terapêutica." (Freud, 1904/2017, p.55).

Nesse mesmo artigo, Freud (1904/2017) define o procedimento usado que possibilita levar das ocorrências ao recalcado, o que chama de arte da interpretação: "a partir das ocorrências, pode-se construir o material inconsciente, bem como instruções acerca de como entender quando as ocorrências dos pacientes falham" (p.55). Perceba-se que é a partir do contexto da técnica livre-associativa colocada em marcha no tratamento que Freud apresenta e articula as noções de intepretação, recalque e resistência em seu texto.

Para a tarefa do método psicanalítico, "nenhum outro caminho leva ao objetivo e, por isso, o caminho mais trabalhoso ainda acaba sendo o mais curto" (Freud, 1904/2017, p.56). Nesse momento, Freud (1904/2017) nos diz que a tarefa psicanalítica pode ser expressa em várias fórmulas: suspender as amnésias, tornar todos os recalques reversíveis, tornar o inconsciente acessível ao consciente. "O objetivo do tratamento nunca será algo diferente do que a cura prática do doente, o estabelecimento de sua capacidade de realizar e gozar" (p.57) ${ }^{7}$.

Freud (1904/2017) centra o objetivo do tratamento, a cura que ele proporciona, em uma melhora significativa no estado geral do doente; os sintomas podem continuar existindo em alguns casos, mas já não tem a mesma importância para o sujeito. Ou seja, Freud parece apontar que, no tratamento psicanalítico, o alargamento dos conteúdos psíquicos acessíveis ao sujeito, proporcionados pela fala em associação livre, seria mais significativo para sua capacidade de realizar e fruir a vida que a remissão completa dos

7 A tradutora, Claudia Dornbusch, nos consta que Freud usa nesse trecho termos mais abrangentes que "trabalhar" e "amar", como é correntemente traduzida essa passagem. Leisten (realizar, produzir) e geniessen (gozar, fruir de modo agradável) "numa tradução menos literal, teríamos: capacidade de realizar (coisas) e gozar (a vida)" (N.T., Freud, 1904/2017, p.61) 
sintomas. Em uma carta a Fliess de abril de 1900, recentemente traduzida para o português, Freud confessava que "A conclusão assintótica do tratamento, que, para mim, é indiferente, continua sendo uma decepção mais para os de fora.” (Freud, 1900/2017, p.48).

Em $O$ método psicanalítico freudiano, a técnica propriamente psicanalítica ganha sua primeira formulação teórica mais abrangente, ou seja, passa, de fato, a existir; vejamos então como a prática do tratamento funcionava dentro do contexto da nova regra fundamental.

\subsection{O tratamento na regra fundamental: primeiros desenvolvimentos}

Freud afirma, em Contribuição à História do Movimento Psicanalítico, de 1914, que o livro da interpretação dos sonhos estava pronto em todo o seu essencial no início de 1896, mas foi redigido somente no verão de 1899, enquanto "o tratamento do caso 'Dora' foi concluído no final de 1899, sua história clínica foi registrada nas duas semanas seguintes, mas publicada apenas em 1905”. (Freud, 1914/2012, p. 266). Assim, a conclusão e a escrita do caso Dora aconteciam ao mesmo tempo em que Freud finalizava seu livro sobre os sonhos, ainda que aquele só fosse publicado quatro anos depois.

Não é fortuito, portanto, que Análise fragmentária de uma histeria, que ocupa mais de cento e cinquenta páginas, esteja centrada, principalmente, na análise de dois sonhos de Dora. No posfácio da obra, Freud admite que com essa publicação pretendia mostrar como a arte da interpretação dos sonhos poderia ser aplicada para desvendar o oculto e o reprimido na vida psíquica, "a técnica da interpretação dos sonhos, que é 
semelhante à técnica psicanalítica" (Freud, 1905/2016, p. 309). Como bem apontou Celes (2007), o caso Dora conjuga a teoria, o processo e a técnica de tratamento, "impondo ou anunciando mudanças imediatas e postergadas" (p.143).

Tratava-se da primeira exposição de um extenso caso clínico de Freud desde os Estudos sobre a Histeria. Já no prefácio, Freud (1905/2016) menciona a possível admiração dos leitores familiarizados com a técnica exposta em Estudos sobre a Histeria ao se depararem com sua impossibilidade de solucionar totalmente os sintomas de Dora no período de três meses que durou seu tratamento; "isso se torna compreensível, porém, se eu informar que desde os Estudos a técnica psicanalítica sofreu uma completa revolução" (p.180). Esclarece aos leitores que a antiga técnica, de abordar cada um dos sintomas para desfazê-los um após o outro, foi abandonada por ser inteiramente inadequada à estrutura mais sutil da neurose.

Agora deixo o próprio doente determinar o tema do trabalho diário e parto da superfície eventual que o seu inconsciente lhe oferece à atenção. Mas assim obtenho fragmentado, entremeado em contextos diversos e distribuído em épocas bem separadas aquilo que está ligado à solução de um sintoma determinado. Apesar dessa aparente desvantagem, a nova técnica é bastante superior à velha, e indiscutivelmente a única possível. (Freud, 1905/2016, p. 309)

Estava firmada a técnica da associação livre como regra do tratamento psicanalítico e Freud nos informa que foi já sob sua égide que o tratamento de Dora se deu. Celes (2007) localiza, na citada revolução sofrida pela técnica que contou Freud, a aplicação da associação livre no seu sentido mais pleno de completa atenção ao discurso 
do analisando: era de Dora a escolha do que dizer. Para o autor, a mudança na técnica está para além do explicitado por Freud:

A atenção de Freud ao discurso de Dora testemunha a virada do privilégio da fala do analisando para o privilégio do ouvir do analista como responsável pelo caráter associativo do discurso.... Permanece, nessa mudança técnica, o fundamento associativo, sendo, porém, dado ao ouvir do analista a sua responsabilidade, e não mais, ou não exclusivamente, às resistências do analisando em falar o que deveria ser dito. Nessa nova política, Freud ouve até mesmo os gestos de Dora, sua brincadeira com a bolsa, por exemplo. (Celes, 2007, p.144)

Freud adverte que, deliberadamente, em Análise fragmentária de uma histeria, “não expus o trabalho de interpretação que tinha de ser realizado com as associações e comunicações da doente, mas somente os resultados dele” (Freud, 1905/2016, p. 181), limitando-se, portanto, a apresentar a técnica do trabalho analítico principalmente no que tange aos sonhos de Dora.

Freud afirma que, caso se tentasse nesse trabalho fundamentar suas regras técnicas, "a maioria delas encontrada empiricamente" (Freud, 1905/2016, p. 181), não produziria nada além de uma inextricável confusão: “achei impraticável lidar simultaneamente com a técnica de uma análise e com a estrutura interna de um caso de histeria ... a técnica exige uma exposição separada, que seja ilustrada com numerosos exemplos extraídos dos mais diferentes casos" (Freud, 1905/2016, p. 307). Chama a 
atenção que Freud, até o final de sua vida, não tenha nunca levado a cabo tal tarefa. Retomaremos a isso no próximo capítulo.

De volta à Dora. Ainda que Freud tenha nos revelado ter omitido o trabalho de interpretação feito com as associações da paciente, tentaremos perceber qual foi a função assumida pela regra fundamental dentro do tratamento de Dora. A serviço do quê a técnica livre-associativa, que Freud contou ser a revolução sofrida na técnica, estava funcionando? Freud (1905/2016) nos dá uma pista quando, logo no primeiro capítulo, em que apresenta o quadro clínico, afirma que sempre inicia os tratamentos com a solicitação de que o paciente conte sua história e fale sobre sua doença.

Os doentes são incapazes de fornecer tais relatos sobre si mesmos. Podem informar de modo suficiente e coerente sobre esse ou aquele período de sua vida, mas logo aparece outro período em que suas comunicações se empobrecem, deixando lacunas e enigmas ... Os nexos, mesmo aqueles ostensivos, estão geralmente partidos" (Freud, 1905/2016, p.185)

Essa é, para Freud, a marca distintiva das neuroses: as lacunas encontradas no discurso do sujeito. Ele as eleva quase ao status de uma ferramenta de diagnóstico diferencial em uma nota de rodapé adjacente. Tal incapacidade dos pacientes de exporem de forma ordenada sua história, na medida em que esta corresponde à história de sua doença, é fundamentada para Freud (1905/2016) em três omissões: na primeira, por motivos de timidez e pudor, o paciente "silencia conscientemente e propositalmente uma parte daquilo que sabe e deveria contar" (p.186); na segunda, uma parte de seu conhecimento, do qual poderia dispor normalmente, é excluída de seu relato sem que 
tenha a intenção de fazê-lo, é a "participação da insinceridade inconsciente" (p.186); por fim, "nunca faltam amnésias verdadeiras” (p.186), lacunas de memória que envolvem não apenas lembranças antigas, mas também outras muito recentes.

Esses três silenciamentos seriam os responsáveis pelos pacientes serem incapazes de fazer um relato adequado sobre si mesmos. Freud adverte que seria apenas durante o tratamento, próximo ao seu fim, que se poderia visualizar uma história clínica coerente, compreensível e sem lacunas. E acrescenta que:

Se o objetivo prático do tratamento é remover todos os sintomas possíveis e substituí-los por pensamentos conscientes, podemos estabelecer como outro objetivo, teórico, a tarefa de curar todos os danos de memória do paciente. As duas metas coincidem; se uma é alcançada, também a outra é obtida, a mesma via conduz a ambas. (Freud, 1905/2016, p.187)

Freud aproxima, desse modo, a solução dos sintomas ao preenchimento das lacunas de memória, afirmando que as duas vias são coincidentes no tratamento. Cura e tratamento se sobrepõem no método psicanalítico regido pela regra fundamental. Retoma, portanto, a fórmula já apresentada nos Estudos sobre a histeria e em A interpretação dos sonhos, mas o faz aqui sobre novos termos: prática e teoria. Apontando, de certo modo, a interposição dessas duas dimensões no tratamento proposto pela psicanálise. Le Guen (1982/1991) faz uma interessante observação sobre o tema quando busca pensar a dialética do método freudiano em relação ao método das ciências naturais: 
Sua prática tem valor experimental, mas ela já é, além do mais, aplicação e generalização; sua prática não se limita a responder a interrogação teórica, tendo em si mesma poder de modificar, sendo resposta à demanda daquilo que em outro lugar seria apenas objeto de experimentação e que se torna aqui sujeito ativo do diálogo analítico: o analisando. Ela é plenamente uma práxis, perfeita dialética da prática e teoria. (Le Guen, 1982/1991, p.32)

Assim, seria durante o efetivo processo de preencher as lacunas (teórico) que o tratamento proporcionava que os sintomas seriam removidos (prática). Preencher lacunas, estabelecer nexos, elucidar enigmas, retificar a memória; parecia serem essas as funções assumidas pela técnica da associação livre no tratamento. A serviço desses objetivos estaria a regra fundamental da psicanálise na concepção freudiana naquele momento. A expectativa de Freud era de que, ao fim desse processo, Dora sairia sem os sintomas.

Durante todo o Análise fragmentária de uma histeria, da parte referente ao quadro clínico à extensa análise dos sonhos, Freud descreve todo seu esforço para tentar cumprir essa tarefa de preencher as lacunas e, com isso, curar Dora. Ele o tentou por diversos caminhos: contraponto as histórias contadas pelo pai de Dora aos relatos dela, precisando datas de fatos ocorridos e os correlacionando aos sintomas, fazendo questionamentos sobre cada lembrança de Dora, observando as atitudes dela no contexto do tratamento para com ele, à exaustão interpretando e elucidando para Dora todos os pensamentos inconscientes contidos em cada um de seus sonhos.

Como apontado por Celes (2007), a escrita final de caso clínico se inseria dentro de um contexto maior da crise da psicanálise com base na teoria do trauma sexual, um momento no qual Freud tentava estabelecer como válida sua teoria da sexualidade, provar 
a etiologia sexual das neuroses, a importância do infantil no adoecimento neurótico. Essas eram talvez outras lacunas que a escrita do caso parecia também tentar preencher.

No relato de seu trabalho com Dora, Freud deixa entrever alguns pontos dignos de nota para compreendermos o uso da regra fundamental nesse momento. Freud (1905/2016) afirma que "geralmente é tarefa do médico adivinhar e completar o que a análise fornece apenas de forma alusiva" (p.218) e ele o faz extensamente durante todo o andamento do caso. Enquanto escutava Dora repetidamente lhe dizer que a Sra. K amava seu pai porque ele era um homem de recursos, "Notei, por algum detalhe em seu modo de expressão ... que atrás da afirmação se escondia seu oposto: que o pai era um homem sem recursos. Isso só podia ser entendido sexualmente” (p.224).

Aqui se encontra, como notado por Celes (2007), a centralidade da regra fundamental no tratamento, não apenas tomada a partir do discurso do analisando, mas residindo na escuta do analista: "O caso narrado por Freud mostra que Dora não se recusa à associação livre. Mostra também que as resistências à associação livre se fazem insignificantes diante da escuta freudiana e de sua consequente interpretação" (Celes, 2007, p. 146). Freud, apoiado nessa escuta associativa, interpreta para Dora seu sintoma da tosse nervosa como resultado de uma fantasia de satisfação sexual através da boca. "O fato de a tosse desaparecer logo depois de ela admitir tacitamente essa explicação se harmonizava bem com minha concepção" (p.226).

Em outro trecho, Freud nos conta que quando comunicou a Dora que não podia deixar de supor que sua inclinação pelo pai já tinha, desde cedo, o caráter de pleno enamoramento, ela lhe deu uma resposta habitual: não se lembrava de nada disso. 
Mas imediatamente contou algo análogo de sua prima de sete anos de idade (por parte de mãe), na qual acreditava ver, com frequência, um reflexo da própria infância. A menina havia presenciado, mais uma vez, uma discussão inflamada entre os pais, e tinha sussurrado no ouvido de Dora, que lá estava de visita: 'Você não imagina como eu detesto essa pessoa (indicando a mãe)! Um dia, quando ela morrer, vou me casar com papai'. (Freud, 1905/2016, p.238-239)

Os mecanismos da negativa (Verneinung) ainda levariam vinte anos para ganharem uma teorização mais elaborada, mas aqui Freud já apontava que, quando seguia adiante com o trabalho analítico após um "não" como o de Dora, estava habituado a encontrar nas associações subsequentes algo que se harmoniza com o teor de sua afirmação inicial, como uma confirmação advinda do inconsciente no processo livre associativo. "Não se escuta outra espécie de 'Sim' do inconsciente; não existe um 'Não' inconsciente.” (Freud, 1905/2016, p.239).

Em outro momento, Freud alude às vantagens de o analista se calar e deixar o fio associativo se desenrolar sem interrupção. Conta que, um dado dia, Dora chegou de péssimo humor, para o qual não tinha explicação alguma além de que era aniversário de seu tio e ela não se decidia a dar-lhe os parabéns, sem saber a razão. "Minha arte interpretativa estava pouco inspirada nesse dia; deixei-a falar e ela se lembrou, de repente, que também o sr. K. fazia aniversário - algo que não deixei de usar contra ela” (p.240).

Na descrição de seu último encontro com Dora, é possível vislumbrar alguns motivos pelas quais o tratamento naufragou. Nele Freud (1905/2016) nos conta que fez para Dora uma extensa e detalhada exposição da análise de seu segundo sonho, em que ficaria evidente seu amor pelo sr. K. bem como os sintomas que tinham tomado seu lugar. 
"Ela ouviu sem contestar como das outras vezes. Parecia tocada, despediu-se muito amavelmente, com votos efusivos de bom Ano-novo e ... não retornou.” (p. 303). Quando Freud se aproxima de preencher as lacunas, Dora não se cura, mas abandona o tratamento. A grafia escolhida por Freud para descrever o momento além de denotar sua decepção, pode ser tomada como curiosamente elucidativa sob outro aspecto. Nos três pontos usados para separar as duas frases, acreditamos poder localizar duas lacunas, de algum modo complementares, com as quais Freud se deparou e que tornaram inviável a continuidade do tratamento.

A primeira delas, Freud (1905/2016) nos aponta no posfácio ao caso, quando percebe que durante a terapia psicanalítica, a produção de novos sintomas é sempre suspensa, mas os efeitos das neuroses não cessam em absoluto. "Toda uma série de vivências psíquicas anteriores e reativada, não como algo do passado, e sim na relação atual com o médico ...” (p.312); trata-se do primeiro passo na elaboração freudiana do fenômeno da transferência no tratamento psicanalítico. Freud (1905/2016) faz questão de frisar que "quando nos aprofundamos na teoria da técnica analítica, percebemos que a transferência é algo necessário e inevitável. Na prática nos convencemos que não há como evitá-la.” (p.312).

Na prática do tratamento. Ou seja, é justamente no tratamento colocado em movimento pela regra fundamental que Freud nos conta se instaurar inevitavelmente a transferência e é onde ele se depara com sua força disjuntiva: “Quando houve o primeiro sonho, em que ela advertia de que deveria abandonar o tratamento ... eu é que deveria ter escutado a advertência e lhe dito: "Agora você fez uma transferência do sr. K. para mim" (Freud, 1905/2016, p. 315). 
O que Freud nos diz, em outras palavras, é que ele não falhou em escutar o que havia de associativo a ele na análise do sonho de Dora, mas que pecou em não levar isso em consideração para o andamento do tratamento e, portanto, Dora foi embora. Aqui podemos localizar a segunda lacuna com a qual Freud se deparou. No caso Dora, Freud percebe que não há, como no sonho, abordagem pura do sujeito. Em psicanálise, em seu trabalho de tratamento, o processo de investigação depreendido do livro dos sonhos não era o suficiente. O sujeito em análise não poderia ser tomado da mesma forma como um sonho a ser interpretado. Havia, no mínimo, uma transferência negativa com a qual o analista sempre tinha que se haver. Nos dizeres de Celes (2007) sobre o funcionamento da associação livre no caso Dora: "exceto no trabalho de simbolizar, significar ou revelar complexos inconscientes, a associação livre encontra seu limite na tarefa de tratamento de cura" (p.146).

Em 1909, Freud publica Observações sobre um caso de neurose obsessiva, conhecido, mais tarde, como o caso do Homem dos Ratos. O tratamento, que se iniciou em outubro de 1907 e perdurou por quase um ano, guarda uma peculiaridade. Dele restaram as anotações que Freud fazia dia a dia, à medida que prosseguia o tratamento, e que serviram de base para o caso clínico posteriormente publicado. Strachey, nas considerações iniciais que precedem a compilação das anotações freudianas, afirma que esse registro "nos dá uma oportunidade única de observar a detalhada elaboração da técnica de Freud na época dessa análise” (Strachey in Freud, 1909/1986, p. 255).

Depreende-se, da leitura tanto desse registro original do tratamento quanto do caso publicado, que a técnica freudiana, após as questões enfrentadas no tratamento de Dora, passava um processo de elaboração no qual o discurso em associação livre do paciente ganhava um papel cada vez mais central. Freud (1909/2013) demonstra que a regra 
fundamental já é para ele o início propriamente dito do tratamento. Em seu segundo encontro com o Homem dos Ratos, ele a enuncia, fazendo o paciente se comprometer a “observar a única condição do tratamento - dizer tudo que lhe vier à mente, ainda que seja desagradável, ainda que lhe pareça insignificante, impertinente e sem sentido -, e deixando ao seu alvitre o tema com que iniciará suas comunicações" (p.18).

O texto do caso publicado por Freud já tem uma singularidade em relação ao formato adotado anteriormente em Dora. Nele, Freud (1909/2013) opta por apresentar o quadro clínico ao leitor transcrevendo, quase literalmente, suas oito primeiras sessões com o Homem dos Ratos. Tece seus comentários a partir do discurso do paciente, fazendo questão de apresentar os momentos em que esse se interrompe e "então prossegue, abruptamente" (p.19), quando fica confuso: “o plural me surpreendeu, assim como terá ficado incompreensível para o leitor" (p.27). Situa, desse modo, seu leitor efetivamente dentro de cada sessão ${ }^{8}$, conduzindo-o sempre a partir do discurso do Homem dos Ratos.

Essa mudança de formato feita Freud não parece fortuita. Se é prioritariamente a partir das associações livres do Homem dos Ratos que Freud tece suas observações sobre o caso e conduz sua teorização sobre a neurose obsessiva, ele aponta o lugar relevante que a dinâmica livre-associativa passou a ocupar, não apenas no tratamento, mas na própria produção de conhecimento a que se propunha.

Comprometido com a regra fundamental no tratamento, o Homem dos Ratos em alguns momentos se exalta em seu discurso, levanta-se do divã e começa a andar pela sala, em outros fica com medo de Freud o surrar tal como fizera seu pai quando criança. São os efeitos do tratamento funcionando a partir da regra fundamental que Freud

\footnotetext{
8 Aqui nos referimos ao texto publicado por Freud, não ao registro do caso que veio a público apenas muitos anos depois.
} 
descreve em Observações sobre um caso de neurose obsessiva. Roussillon (2004) lembra que é a partir dessa experiência da regra fundamental no tratamento do Homem dos Ratos que Freud pode conceber que as "associações são, de fato, organizadas de maneira latente pela existência de 'complexos representativos inconscientes', ou seja, de organizadores fantasmáticos inconscientes, que asseguram uma certa função de síntese do discurso" (p.12). Nos momentos em que a função de síntese do discurso de alguma forma não é suficiente ou é ameaçada no próprio andamento do processo livre-associativo do tratamento, o sujeito experimenta algo "como exposição a uma ameaça de loucura" (Roussillon, 2004, p.12).

Um momento singular dessa descrição freudiana do caso é digno de nota. O Homem dos Ratos, em um dado dia, escolhe contar a Freud sobre um episódio ocorrido durante os exercícios militares, em que um capitão do exército de sobrenome tcheco lhe relata ser a favor de um cruel castigo corporal infringido no Oriente. Mas, relata Freud:

Aqui ele se interrompe, levanta-se e me pede para dispensá-lo da descrição dos detalhes. Eu lhe asseguro que não tenho inclinação alguma para a crueldade, que certamente não desejo atormentá-lo, mas que, naturalmente, não posso concederlhe algo que não está em meu poder. Seria, digamos, como se ele me pedisse para lhe presentear com um cometa. (Freud, 1909/2013, p. 26)

No momento em que a associação livre conduzia o Homem dos Ratos a contar sobre o castigo com os ratos, o relato se interrompe. Nesse instante, Freud lhe diz que não pode livrá-lo de continuar a associar, que não estaria em seu poder dispensá-lo de dizer suas associações. Ferenczi (1918/1992), em uma conferência em Budapeste, na qual discute 
os abusos da liberdade de associação que certos pacientes fariam, comenta um caso em que foi obrigado "em contradição formal com a regra psicanalítica, a convidar o paciente a dizer sempre até o fim a frase que tinha começado" (p. 360). O autor nos conta ter notado que sempre que o caminho associativo assumido pelas ideias desse paciente o levava a caminhos desagradáveis, “ele jamais a concluía e, com um 'a propósito’ bem no meio, passava a falar de coisas secundárias, sem importância” (p. 360). Seu paciente, se valendo da regra fundamental, a usava para não ter que dizer.

Ferenczi (1918/1992) completa: “foi preciso explicar-lhe que a regra fundamental não exigia, certamente, que se pensasse até o fim uma ideia, mas, sem dúvida alguma, exigia que se dissesse até o fim o que já havia sido pensado" (p. 360). No tratamento sob a regra fundamental, em consonância com o que apontou Freud para o Homem dos Ratos, Ferenczi nota que era necessário dizer de uma ocorrência (Einfall) até o fim. Era preciso ao paciente percorrer sua associação pelo ato da fala, algo de significativo para o tratamento residia nesse gesto. Mas, retornemos a 1909, para entender o quê.

Chervet (2016) afirma que a obsessão do paciente pelos ratos, durante muito tempo inconfessa, era o nó figurativo que canalizava, conduzidos pelo erotismo anal, todos os fios associativos do conflito interno. A intervenção de Freud, sustentando que a associatividade não poderia ser deixada de lado, visava diretamente a romper as defesas do Homem dos Ratos pela imprecisão ou pela omissão. Ainda para Chervet (2016), o trabalho de elaboração que se organizou em torno da figuração do suplício com os ratos construiu um tecido associativo de imagens e palavras que familiarizou o paciente com os conteúdos recalcados e os inscreveu em um registro em que esses podiam ser assumidos pelo Eu do Homem dos Ratos. 
Kehl (2002) sustenta que é exatamente esse o grande potencial terapêutico da descoberta freudiana. $\mathrm{O}$ acesso à palavra corresponde ao deslocamento de uma parte da energia psíquica, do sistema inconsciente à consciência, na qual a descarga de energia livre sobre uma representação de palavra transforma parte da energia livre do inconsciente em energia ligada.

A descrição desse processo deixa evidente a razão pela qual a palavra que permite a expressão do recalcado deve ser dita pelo analisando e não comunicada a ele pelo analista, como Freud bem percebeu nos primeiros anos de sua experiência analítica, ao decidir substituir o método da hipnose pelo da associação livre. (Kehl, 2002, p.123).

Freud não podia isentar o Homem dos Ratos de continuar seu relato, nem o fazer em seu lugar, justamente porque dependia de seu dizer, em associação livre, o efeito terapêutico do tratamento psicanalítico. Ou seja, desse dizer dependia o deslizamento entre as noções freudianas de processo primário - que se assenta em um fluxo de associatividade livre - para o processo secundário, no qual a associatividade em consonância com a realidade opera ligações, o que Green (2000) nomeou como trabalho de Eros. Há, portanto, nessa postura fundamental de Freud, algo que aponta para o funcionamento elaborativo do próprio discurso, guiado pela regra fundamental no tratamento, para a existência de uma fala associativa em análise que seria em si mesma terapêutica, proporcionaria cura. Em uma nota de rodapé, em que discorre sobre o fato desse paciente lhe dizer que uma dada interpretação soava plausível, mas não lhe dava mostras de estar, de fato, convencido, Freud esclarece que: 
O propósito de tais discussões não é jamais o convencimento. Elas devem apenas introduzir os complexos reprimidos na consciência, avivar a luta em torno deles no terreno da atividade psíquica consciente e facilitar a emergência de novos materiais do inconsciente. A convicção vem somente após a elaboração do material readquirido pelo doente. (Freud, 1909/2013, p. 41)

Portanto, com o que dizia no tratamento, Freud não estava preocupado em convencer, mas em dar continuidade ao processo associativo do paciente; adviria dele o processo elaborativo que alcançaria o convencimento. A questão será retomada no próximo capítulo. 


\section{Capítulo 3}

\section{Associação-Livre: fundamento do trabalho de Psicanálise}

Uma parte de mim é todo mundo; outra parte é ninguém: fundo sem fundo.

Uma parte de mim é multidão: outra parte estranheza e solidão.

Uma parte de mim pesa, pondera; outra parte delira.

Uma parte de mim almoça e janta; outra parte se espanta. Uma parte de mim é permanente; outra parte se sabe de repente.

Uma parte de mim é só vertigem; outra parte, linguagem.

Traduzir-se uma parte na outra parte — que é uma questão de vida ou morte - será arte?

Ferreira Gullar, Traduzir-se, Na Vertigem do Dia. 1980.

\subsection{A técnica definida por sua ética fundamental}

Freud, no conjunto de todos seus escritos, não dedicou nenhum trabalho de maior extensão exclusivamente à exposição sistemática do conjunto da técnica psicanalítica, embora tenha enunciado, em mais de uma ocasião, a pretensão de fazê-lo, como apontamos no capítulo anterior. Nunca existiu um tratado completo sobre a questão da técnica em psicanálise, ainda que, segundo Lacan (1953/1986), toda a obra freudiana possa ser lida como uma detalhada exposição de sua técnica.

Contudo, logo antes da deflagração da Primeira Grande Guerra, entre 1911 e 1914, Freud escreveu um conjunto de seis textos, reunidos pelo próprio autor em 1918 e publicados em uma compilação de artigos breves intitulada Sobre a técnica da psicanálise 
(Strachey in Freud, 1911-1915/1987, p. 112). Alguns desses apresentam discussões relativamente aprofundadas de problemas técnicos no contexto do tratamento, noutros encontramos mais o intuito freudiano de apresentar conselhos, dicas e advertências. Em carta a Ferenczi, escrita em 1928, Freud lembra que todas as suas recomendações dessa época eram de natureza essencialmente negativa: "Eu considerava que o mais importante a ser enfatizado era o que alguém não deveria fazer, demonstrar as tentações que trabalham contra a análise.” (Freud e Ferenczi apud Coelho Junior, 2004, p. 76). Nesse sentido, acrescentam Iannini e Tavares (2017), “quem acorre aos textos ditos técnicos procurando por regulamentos ou instruções corre o risco de se frustrar ou depreender dali a, talvez, única regra fundamental: a da livre associação" (p.9). Veremos, portanto, de que modo alguns desses textos se articulam com a técnica livre-associativa freudiana.

No começo de Recomendações ao médico que pratica a psicanálise, de 1912, Freud escreve que todas as regras técnicas que oferecerá no texto podem se resumir a um único preceito, que acaba por não anunciar de início. Freud (1912b/2010), adotando um formato esquemático em seu texto, desaconselha que o analista tente voluntariamente reter na memória todos os detalhes do caso que está tratando ou anote qualquer coisa durante o andamento das sessões, bem como aconselha que aguarde até a conclusão de um caso para trabalhar cientificamente sobre ele, evitando fazer previsões ou comparações. Enfaticamente, Freud (1912b/2010) recomenda que o analista tome para si o modelo da frieza de sentimentos com o qual um cirurgião leva a termo uma operação e, finalmente, complementa:

É fácil ver para qual objetivo essas diferentes regras convergem. Elas pretendem criar, para o médico, a contrapartida da 'regra fundamental da psicanálise' 
estabelecida para o analisando. Assim como este deve comunicar tudo o que sua auto-observação capta, suspendendo toda objeção lógica e afetiva que procure induzi-lo a fazer uma seleção, também o médico deve colocar-se em uma posição de utilizar tudo o que lhe é comunicado para os propósitos da interpretação, do reconhecimento do inconsciente oculto, sem substituir pela sua própria censura a seleção a que o doente renunciou. (Freud, 1912b/2010, pp. 155-156)

Assim, Freud (1912b/210) revela que o preceito que guia todas suas recomendações é na verdade duplo: à regra fundamental (Grundregel) da associação livre colocada ao paciente se combina a atenção flutuante que orienta a escuta do analista; a segunda é a decorrência coerente da primeira, seu desdobramento técnico. Portanto, não nos parece fortuito que, no trecho imediatamente posterior, Freud (1912b/2010) afirme que a melhor maneira de o analista alcançar tal "posição" seja ocupando o lugar de paciente, ou seja, falando em associação livre para um outro analista.

Como lembra Celes (2008) é na noção freudiana da abstinência que se constitui a condição na qual se sustenta a atenção flutuante; a escuta flutuante do analista é correlacionada e dependente de sua posição em abstinência. De modo que atenção flutuante, abstinência e discurso em associação livre se conjugam todo o tempo no tratamento psicanalítico: "Ouvir em atenção flutuante, propiciado pela abstinência, é a condição necessária para se fazer da fala do analisando uma associação livre" (para. 10). A escuta flutuante é a contrapartida da regra fundamental, Freud esclarece, não outra regra fundamental; o método psicanalítico só teria um fundamento técnico: a associação livre. 
Assim, nesse momento, Freud (1912b/2010) parece dar a entender que é a atenção flutuante do analista que faz o sujeito associar; em outras palavras: é a escuta flutuante do analista que recolhe o que existe de associativo na fala do sujeito no tratamento psicanalítico. Bollas (2005) sugere que quem produz a associação livre é mais a escuta do analista que a fala do analisando, muito mais que a fala em associação livre, que para o autor é algo corriqueiro, é a escuta propiciada pelo par freudiano que faz a marca distintiva da psicanálise: "esse modo de escutar é revolucionário" (p.14).

Como lembrou Celes (2007), esse entendimento da íntima conjugação entre fala em associação livre e atenção flutuante já estava, de alguma forma, presente para Freud desde Dora, ainda que de forma não explícita, na revolução pela qual o autor contou ter passado a técnica naquele momento. Para Celes (2007), Freud colocou "o privilégio do ouvir em detrimento da associação, como tarefa exclusiva do analisando, não se esperando dele um discurso permanentemente deslizante e sempre associado e frequente" (p. 144).

Green (1988) sugere que sendo o discurso do analisando em associação livre sempre de alguma forma "narrativo-recitativo" (p.72) cabe ao analista, à sua escuta flutuante, ser capaz de ouvir o que existe de associativo nele. Trata-se, como afirma Freud (1912b/2010), de se alcançar uma "posição" essencial e diferenciada do analista para que aconteça a associação livre no contexto do tratamento. Ainda que o analista possa também ele associar, a situação analítica não configura uma dupla associativa. $\mathrm{O}$ tratamento nomeado por Freud como Psicanálise requer o desdobramento em duas posições diferentes, mas complementares, de fala e escuta associativas.

Segundo Lysy-Stevens (2000), “A regra fundamental assim desdobrada privilegia a dimensão da surpresa" (p. 20). Para a autora, toda a série de regras enunciadas por Freud 
nesse texto é derivada desse desdobramento essencial. As demais "recomendações" que Freud expressa não parecem constituir protocolos tão rígidos, antes expressam princípios ou fundamentos gerais que regem a prática clínica. Com exceção da regra livreassociativa - e sua contrapartida única da escuta flutuante - todo o mais parece ter um estatuto menos inflexível para Freud.

Em A dinâmica da transferência (1912a/2010) e Observações sobre o Amor de Transferência (1915/2010), Freud aponta para o imenso inconveniente metodológico da transferência como resistência ao tratamento: ela interfere no pleno funcionamento do método. "Tenhamos em mente, sobretudo, a suspeita de que tudo o que atrapalha a continuação da terapia pode ser uma manifestação da resistência" (Freud 1915/2010, pp. 214-215). Freud nos conta que a interrupção completa do processo livre-associativo do paciente está sempre vinculada a um pensamento de transferência em relação ao analista. Quando, no contexto do tratamento, algo do material do complexo reprimido se presta a ser transferido para o analista, a transferência "produz a associação seguinte e se anuncia mediante sinais de resistência como uma interrupção, por exemplo. Dessa experiência inferimos que essa ideia transferencial irrompeu até a consciência antes de todas as outras associações possíveis porque satisfaz também a resistência” (Freud, 1912a/2010, p.140).

Ou seja, Freud (1912a/2010) nos conta que não apenas a interrupção do processo de associação livre materializa no tratamento o aparecimento do fenômeno transferencial, mas que é provocada por ele. A ideia transferencial é, ela mesma, uma associação interrompida, muda, associada à resistência do sujeito. De acordo com Loyola (2005), “como a associação livre não é um monólogo, mas 'palavra' dirigida a alguém, temos aqui a consolidação da transferência" (p.177), seu aparecimento é uma consequência da processo livre-associativo em marcha no tratamento. 
Como lembra André (2015): “A associação livre é um meio, não o objetivo visado pela regra - um dos modos de resistência consiste, aliás, em seguir a regra ao pé da letra e só falar coisas sem pé nem cabeça" (pp. 134-135). Assim, quando o analisando toma a regra fundamental "ao pé da letra" enquanto regra, ele se aproxima mais de um discurso maníaco, a serviço da resistência, que de uma fala, de fato, livre-associativa. Sob os auspícios da transferência o sujeito pode se calar ou falar de forma maníaca, fazendo, em ambos os casos, da regra proposta um meio de expressão da resistência enquanto fenômeno transferencial.

Donnet (2001) nos conta que "Freud não esperava que a regra, de um modo objetivante, em terceira pessoa, garantisse imparcialmente a plena manifestação do jogo de forças em conflito" (p.232). Se, como consequência do tratamento, o analisando, sob o domínio do fenômeno transferencial, se permite então "a liberdade de ignorar a regra psicanalítica básica ... esquece os propósitos com que iniciou o tratamento (Freud, 1912a/2010, p. 145), nos diz Donnet (2001) que:

Constatamos que a regra, tida como servindo a priori para a investigação de um conflito intrapsíquico, perde essa condição de meio para se tornar questão inconsciente na cena analítica. Não tem mais o valor de referência terceira. Mas conservou uma pertinência funcional, pois o paciente produziu um sintoma transferencial interpretável. (Donnet, 2001, p. 234)

Por fazer da resistência ao analista uma resistência à análise, a complexidade do fenômeno transferencial desqualifica a função de terceiro da regra fundamental, mas não cessa a possibilidade de a análise continuar, ao produzir um sintoma transferencial 
interpretável pelo analista. Exige, portanto, da escuta e da interpretação do analista que tomem para si a função de terceiro da análise, embora a transferência intente transformálo (analista), a todo o tempo, em segundo. Freud (1910a/2010) parecia se fiar em tal convicção quando, ao final do texto, afirma que, com todos os inconvenientes trazidos para o tratamento com os fenômenos transferenciais, "eles prestam o inestimável serviço de tornar atuais e manifestos os impulsos amorosos ocultos e esquecidos dos pacientes, pois afinal é impossível liquidar alguém in absencia ou in effigie" (p.146).

Ao diferenciar os dois tipos de transferência presentes no tratamento é como se Freud (1915/2010) apontasse que é por amor ao analista, pela transferência positiva (que é diferentemente da paixão pelo analista, entendida aqui como uma transferência negativa) que o sujeito fala em associação livre e, teorizando-a como o motor do tratamento, mostra seu potencial para tratar o psiquismo. Parece ter sido neste entrecruzamento entre a transferência e o processo livre-associativo que o psiquismo se desnudou mais a fundo para Freud. Roussillon (2012) aponta essa íntima vinculação quando nos diz que "quando nos debruçamos sobre a questão dos fundamentos da psicanálise somos, imediatamente, confrontados com a questão da associatividade e, acoplada a ela, com a da transferência.” (p.8).

Em O Início do Tratamento, Freud faz questão de dar destaque no texto a uma de suas recomendações: "Enquanto as comunicações e os pensamentos espontâneos do paciente ocorrerem sem interrupção, não se deverá tocar no tema da transferência" (Freud, 1913/2010, p.186). Para Freud (1913/2010), a transferência era o mais delicado dos procedimentos e apenas deveria ser abordada quando se tornasse uma resistência ao processo analítico. Sobre o tratamento propriamente dito, Freud (1913/2010) é enfático ao escrever que não importa por onde o relato comece, "deve-se permitir que o paciente 
fale, deixando à sua escolha o ponto de partida (p.180)". Neste momento do texto, Freud enuncia a famosa metáfora do passageiro como o modelo que deveria ser seguido pelo analisando no tratamento:

Comporte-se, por exemplo, como um viajante que está sentado à janela do trem e descreve para seu vizinho, alojado no interior, como se transforma a vista ante seus olhos. Enfim, não se esqueça jamais que você prometeu sinceridade absoluta, e nunca passe por cima de algo porque por alguma razão lhe é desagradável. (Freud, 1913/2010, p. 181)

A metáfora freudiana é marcadamente visual, tenta colocar o sujeito submetido à associação livre como um observador externo de seu próprio processo mental. De certo modo, esse modelo de "tomar notas" se aproximava da técnica que Freud usou para interpretar seus próprios sonhos, associando sempre a partir de suas anotações escritas à mão; tratava-se de uma associação livre escrita, não falada. (Anzieu ,1989).

Donnet (2001) define assim tal modelo do viajante: "O método postula um ego sujeito do conhecimento, capaz de observar uma parte de seu mundo interno para tornálo um objeto de investigação" (p. 228). Pressupõe, assim, a necessidade de uma separação funcional no sujeito. Viera (2008) faz uma interessante releitura da mesma metáfora freudiana, postulando que a cena delimita um tipo muito especial de movimentação: "Lide com seus pensamentos e comigo como se descrevesse a um cego o que vê pela janela de um trem em movimento. ... $\mathrm{O}$ analista não vê, mas dirige. $\mathrm{O}$ analisante olha, porém não enxerga" (p.136). Viera (2008) aponta que o recurso à associação livre, ao se entrar em uma análise, leva a um “engano fundamental. Entramos no jogo movidos pelo desejo de 
esclarecer um mistério ... apenas para descobrir ao longo da investigação o quanto os encontros no caminho são de muito mais importância" (p. 136). Dois encontros: aquele entre analista e analisando (a transferência), e o que tem o analisando com o que diz de si falando em associação livre.

Tal dimensão de engano, intrínseco à regra livre-associativa, não estava de nenhum modo distante do pensamento freudiano. Em uma extensa nota de rodapé adjacente à metáfora do trem, Freud (1913/2010) fala de sua experiência com a regra fundamental, afirma que, ainda que seja indispensável enunciá-la no início de cada tratamento, o sujeito, em algum momento e pelas mais diversas razões, irá boicotá-la. "Podemos nos convencer da pouca eficácia desses contratos que firmamos com o paciente, ao apresentar a regra fundamental, quando pela primeira vez surge algo íntimo a comunicar" (p. 181).

O que Freud (1913/2010) sugere em sua nota é que não se trataria de uma questão de boa ou má vontade por parte do analisando, o recurso à associação livre no contexto do tratamento não se dá de forma espontânea e sem percalços. Ela demanda um trabalho psíquico do analisando em vencer fortes resistências e exige observação constante do analista. Ele, analista, deve agir de modo a favorecer esse trabalho em associação livre: desaconselhando ao paciente que prepare cuidadosamente o que vai dizer na sessão para aproveitar o tempo, não permitindo abrir exceção em nenhum ponto (conteúdos desagradáveis, sigilo profissional, a exclusão de nomes de terceiros e etc.).

Ao nos contar de uma regra técnica fundamental que inevitavelmente terá que ser enunciada e resguardada pelo analista, ainda que esse mesmo analista possa ter a certeza de sua desobediência vindoura, Freud (1913/2010), por um lado, preserva e acentua o valor da associação livre como fundamento no tratamento psicanalítico e, por outro, retira 
muito do peso do termo regra em seu estatuto. Em outras palavras, a negação da associação livre como regra pelo paciente é parte intrínseca e esperada do próprio processo de tratamento; entretanto, se ela perde força como regra a ser necessariamente observada pelo analisando o tempo inteiro, ela não pode, para Freud, ser deslocada de seu lugar de norteador fundamental do trabalho em psicanálise.

Sem o dizer explicitamente, o que Freud nos apresenta é um curioso paradoxo: estaríamos em algo muito distante de um tratamento do tipo psicanalítico se acaso a associação livre fosse sempre a regra na fala do sujeito em análise. André (2015) lembra que, no que tange à regra fundamental, o que enuncia o psicanalista é uma coisa, o que entende o paciente é sempre outra completamente diferente. Nesta perspectiva, Donnet (2001) pensa que a maneira de apreensão da regra fundamental feita por cada analisando particular vai dar a singularidade de cada experiência analítica, em uma medida tão extrema quanto a transferência com a pessoa do analista também o faz: "Alguma coisa essencial ao método se dá na auto-apropriação por meio da qual o paciente se torna um analisando" (Donnet, 2001, p. 230). Para o autor, o sentido primeiro da associação livre seria fazer do paciente o agente ativo do método - o que não era possível, em amplitude, nas técnicas hipnóticas e de pressão na testa:

Sua auto-apropriação pelo paciente é relativamente independente do analista, e permite que ele se torne, de um modo suficientemente autônomo, um analisando. Sabemos a que ponto as tentativas para ensinar o ofício de analisando ao paciente, para explicitar um modo de operar, são mais ou menos inúteis. Para abranger uma apropriação que constitui uma reinvenção, é preciso evocar o paradoxo do achadocriado winnicottiano que, no fundo, corresponde ao que a espontaneidade da 
transferência tem de criativo. O papel do analista nessa apropriação seria, antes de qualquer coisa, o de não impedi-la. (Donnet, 2001, p. 237)

Logo, a partir desse binômio desobediência-apropriação singular do sujeito da regra fundamental, podemos pensar na existência de uma transferência com a própria situação analítica proposta e ensejada pela técnica livre-associativa. Esta transforma cada tratamento em uma experiência radicalmente particular, no qual a regra postulada pelo método é sempre encontrada e reinventada pelo sujeito singular. Vaz (1988) encontra na normatividade lúdica do jogo uma profunda analogia com o fazer científico e sua ética intrínseca:

Sendo a ciência um desafio permanentemente renovado ao homem pela natureza, fonte de enigmas, mas que não pode ser vencido senão através da submissão a um complexo sistema de regras, constituindo assim uma experiência privilegiada - tal como o jogo - da síntese entre a liberdade e a norma, na qual se reconhece a essência da atividade ética. (Vaz, 1988, p. 215)

Na medida em que entendemos, seguindo Vaz (1988), a ética como uma práxis ou realização do sujeito instituída de modo dialético com a normatividade, acreditamos, portanto, localizar uma certa dimensão ética instituída pela associação livre no tratamento, a partir do momento em que ela configura uma apropriação particular da regra em cada situação analítica, que, como nos disse Donnet (2001), cabe ao analista não impedir para que algo de singular do sujeito possa comparecer. Tal apropriação institui, assim, para cada análise uma referência que se dá sempre a partir dos elementos internos 
ao próprio trabalho singular de tratamento, nunca fora dele. Mais adiante abordaremos outra dimensão ética da associação livre no tratamento psicanalítico, antes retomaremos um ponto deixado inconcluso em nosso segundo capítulo: o potencial elaborativo da associação livre no tratamento.

Como parte integrante do conjunto de textos que abordavam especificamente a técnica analítica, Freud publica, em 1914, o curto e denso artigo Recordar, repetir e elaborar. Para Celes (2013), o que surge nesse momento do pensamento freudiano é a ideia de uma capacidade elaborativa presente na própria associação livre, que retira do analista o peso da função sintética no momento da interpretação dos conjuntos associativos produzidos em análise. O processo livre associativo propriamente dito seria capaz de conduzir o sujeito a uma certa consciência de si: "A associação elabora, possui natureza reflexiva, esta sendo seu efeito, não sendo sua meta ou seu objeto” (pp.207-208).

O que Freud (1914/2017) parece estar colocando em questão nesse artigo são os limites da rememoração do sujeito no tratamento analítico. O autor abre seu texto advertindo sobre as profundas transformações que a técnica analítica sofreu. Separa então três momentos díspares: 1) "Primeiro, na fase da catarse de Breuer, o foco se dava sobre o momento de formação dos sintomas ... Naquela época, lembrar e ab-reagir eram os objetivos a serem atingidos por meio do estado hipnótico" (p.151). Após a renúncia à hipnose, 2) "tornava-se premente a tarefa de inferir a partir das ocorrências do analisando, aquilo que ele não conseguia lembrar. Através do trabalho de interpretação e da comunicação de seus resultados ao paciente, objetivava-se contornar a resistência" (p.151). Por fim, constitui-se o que era, para Freud, a técnica atual da psicanálise, na qual o analista 3) "abdica do estabelecimento de um determinado momento ou problema e se contenta em estudar a superfície psíquica do analisando, usando a arte da interpretação 
basicamente para reconhecer as resistências que surgem ali e para torná-las conscientes" (p. 152). Freud (1914/2017) fala de um novo tipo de divisão de trabalho que se instaurou então: "o médico revela as resistências que eram desconhecidas do paciente; sendo estas dominadas, muitas vezes o paciente narra sem qualquer esforço as situações esquecidas" (p.152).

Note-se que, apesar da técnica livre associativa estar presente tanto no segundo quanto no terceiro momentos descritos, Freud (1914/2017) nos diz que ela funciona de modo diferente em cada um deles: antes a interpretação do analista visava a "contornar a resistência", agora serve para "reconhecer" e "revelá-las". O lembrar do analisando adviria no segundo momento, das inferências do analista comunicadas ao analisando; no terceiro seria mais um efeito da continuidade da narração do sujeito, portanto, do prosseguimento do processo livre-associativo.

Ainda que Freud (1914/2017) afirme que o objetivo final das três técnicas continua sendo o mesmo: "o preenchimento de lacunas de lembrança" (p.152), ele discorre sobre novos obstáculos à rememoração que se apresentaram ao analista desde o método hipnótico: as lembranças encobridoras, as fantasias e os tipos especiais de vivências "extremamente importantes, que fazem parte dos primórdios da infância (p.154)", as quais, geralmente, o analista não consegue fazer evocar na forma de uma lembrança. Freud nos diz que, ao se colocar a nova regra em prática, sobra muito pouco de um percurso sem obstáculos para a lembrança:

Podemos dizer que o analisando não se lembra mais de nada do que foi esquecido ou recalcado, mas ele atua com aquilo. Ele não reproduz como lembrança, mas como ato, ele repete sem, obviamente, saber que o repete ... Ele começa o 
tratamento com a repetição. Frequentemente, quando se informa a regra psicanalítica fundamental a um paciente ... e se convida o paciente a dizer o que lhe ocorre esperando que suas informações brotem em torrente, temos a experiência inicial de que ele não tem nada a dizer. Ele se cala e afirma que nada lhe vem à mente. É evidente que isso nada mais é que a repetição ... enfim, entendemos que esse é o seu modo de lembrar. (Freud, 1914/2017, p. 154-155).

O que Freud (1914/2017) nos conta é que a regra fundamental, nesses casos, não vai fazer o sujeito lembrar e falar, mas repetir. Sob o domínio da transferência, o sujeito irá associar suas vivências infantis à figura do médico e atuar, ao invés de produzir uma lembrança por meio de sua fala. Em suma, a regra fundamental fará o sujeito continuar associando, não através de seu discurso, mas em seus atos em relação ao analista. Do “fazer lembrar na hipnose" (p.157), chega-se ao "fazer repetir durante o tratamento analítico segundo a técnica mais recente" (p.157). É esse o abacaxi que Freud apresenta à técnica psicanalítica em 1914: os limites da rememoração e do falar durante o processo livre-associativo do tratamento.

No entanto, nos diz Freud (1914/2017), para o analista “o objetivo continua sendo lembrar à moda antiga, o reproduzir em âmbito psíquico, ao qual ele se atém, mesmo sabendo que com a nova técnica ele não poderá ser alcançado" (p.158). O que Freud (1914/2010) sugere ao analista é que suporte e continue o "trabalho de lembrar" (p.158) o que o paciente quer descarregar através da ação. A esse trabalho, Freud parece dar um nome específico: 
Precisamos dar tempo ao paciente para que ele se aprofunde na resistência que até então lhe era desconhecida, para perlaborá-la, superá-la, na medida em que ele, a ela resistindo, continua o trabalho de acordo com a regra analítica fundamental ... O médico não tem mais nada a fazer aí senão esperar e aceitar um percurso que não pode ser evitado e que também nem sempre pode ser acelerado. (Freud, 1914/2017, p. 161)

O que Freud (1914/2017) aconselha é dar tempo ao paciente para, na medida em que prossegue o trabalho em conformidade com a regra fundamental, esse percurso seja atravessado e "só no ponto mais alto desse trabalho é que ... o paciente se convencerá através dessa vivência" (p.161). Reside, assim, no próprio trabalho continuado em associação livre e proporcionado por seu atravessamento - que não pode ser abreviado ou contornado e tem que ser sustentando pelo analista - a possibilidade de algum acesso à lembrança e a consequente convicção por parte do sujeito. Nesse sentido, o que Freud chama de convicção advinda da vivência nos parece ser fruto da continuidade, lenta e gradual, do processo de falar em associação livre, ou seja, do trabalho de perlaboração. ${ }^{9}$ Resende (2001), em uma investigação aprofundada sobre a noção de perlaboração na obra de Freud, faz uma importante diferenciação entre os processos de trabalho próprios do aparelho psíquico (elaboração) e o trabalho efetuado no tratamento analítico (perlaboração): "Poder-se-ia pensar a perlaboração como o trabalho na análise de

\footnotetext{
9 Não é escopo específico desse trabalho adentrar na discussão sobre a melhor tradução do termo Durcharbeiten usado por Freud para nomear seu trabalho. Optamos pela mais conhecida tradução do título (Recordar, repetir e elaborar) por razões práticas de situar o leitor. No entanto, concordamos com a tradutora da versão consultada, Claudia Dornbusch, quando opta pelo termo perlaborar, pois "bearbeiten significaria algo próximo de 'elaborar'. "Entretanto, Freud usa aqui o prefixo durch-, muito próximo de through na língua inglesa. Quer dizer, há aqui a noção de um atravessamento que perfaz uma ação." (Nota da tradutora, p. 162-163). Tal opção, acreditamos, ficará mais clara no parágrafo seguinte.
} 
percorrer/incidir sobre as complexas associações que o aparelho psíquico construiu. Isto é, a perlaboração seria o caminho inverso ao trabalho do aparelho psíquico, à organização do material psíquico" (p.14)

Assim, para Resende (2001), ainda que existam aproximações entre elaboração e perlaboração na obra freudiana, essas aparecem relacionadas a fenômenos e trabalhos diferentes. Na nova divisão do trabalho apontada por Freud em 1914, "A ab-reação foi substituída pela perlaboração” (Resende, 2001, p.19). A autora identifica na proposta freudiana um trabalho de temporalização efetuado pela perlaboração, no qual reside o principal fator de eficácia terapêutica do método psicanalítico, que "deixa de ser uma busca do passado em uma perspectiva causal e torna-se um convite ao analisando a falar enquanto está repetindo" (Resende, 2001, p.23). Ou seja, um convite a continuar dentro do processo associativo proposto pela regra fundamental, mesmo sob os efeitos da compulsão à repetição. Como apontou Resende (2001), retomando Pontalis:

A injunção originária 'lembre-se' foi substituída pela prescrição 'associe' ... Assim, a associação livre é renúncia ao controle da palavra, a seu uso comunicativo, expressivo ou representacional ... O recordar assume então a forma de uma temporalização onde os tempos estão indiferenciados e introduz a partir da associação livre, enquanto modo - mimetizando o processo primário - onde se instala a transferência. (Resende, 2001, pp.64-65).

Acreditamos, portanto, que o que Freud (1914/2017) define como perlaboração se aproximaria do trabalho propriamente dito empreendido pela associação livre no contexto do tratamento levado adiante pelo analista: "A perlaboração faz a elaboração acontecer" 
(Resende, 2001, p.110); no tratamento, a continuidade da associação livre elabora. A fala em associação livre, quando efetivamente associativa, elabora, sugere Freud. A fala associativa é, em si mesma, tomada como exercício da elaboração. Pensamos não ser extrapolar em demasia o pensamento de Freud caso sugeríssemos estar presente em sua noção de perlaboração (trabalho elaborativo da associação livre) algum deslocamento possível pelo trabalho de análise da "compulsão à repetição" ensejada na transferência, para a "compulsão à associação" presente na vida psíquica e nos sonhos, como apresentamos anteriormente.

Em uma perspectiva diferente, mas a nosso ver complementar, Green (2004) aponta a existência de um processo elaborativo intrínseco ao silêncio presente no tratamento em associação livre: "o enquadre analítico induz a produção de um discurso, que a interpretação conduzirá ao silêncio de pontuação, seguido de um novo lance associativo" (p.18).

Para Green (2004), o silêncio tem uma função estruturante no tratamento negativo ou tela de fundo na qual as projeções e pensamentos associativos do analisando vão se inscrever e se movimentar -, ele é a condição a priori da interpretação do analista: "A função silenciosa é complexa. Ela mora nas cavidades do discurso do paciente, é a sombra desse discurso, sua negatividade. Por ocasião da associação livre, esta função está delegada ao analista. (Green, 2004, p. 18). Para o autor, o silêncio no tratamento só pode ser compreendido no conjunto de condições inerentes e constitutivas do enquadre analítico, seu sentido só se elucida na passagem do método ao tratamento psicanalítico.

Da leitura empreendida até o momento, pensamos poder localizar na regra técnica da associação livre o norteador principal que Freud usa para definir o enquadre analítico que apresenta em seus textos a respeito da técnica psicanalítica. De modo que, tudo no 
método psicanalítico trabalha em favor da continuidade do processo de livre associação. Para Donnet (2001), o método psicanalítico se apresenta como uma operação controlada das condições por meio das quais a associação livre se revela praticável, interpretável e benéfica:

A regra supõe que a atividade associativa, por meio da heterogeneidade dos significantes empregados (Green) e da diversidade das modalidades enunciativas, não seja apenas um meio, habitada pelo distanciamento do sujeito consigo próprio, ela é a oportunidade de uma percepção tangível e perturbadora da outra cena: a experiência dessa derivação toma o único sentido 'o objetivo, este é caminho'. (Donnet, 2001, p. 232)

O recurso à associação livre não é um fim em si mesmo, ele extrapola a produção de material inconsciente, proporciona uma experiência singular ao sujeito no decorrer do tratamento. "O essencial do trabalho analítico, seu método, efetua-se pela linguagem e por intermédio da linguagem. A linguagem faz parte dessa aparelhagem psicanalítica que é o enquadre" (Delouya, 2003, p. 38). Se, como podemos depreender do percurso seguido até aqui, Freud não abre mão de postular que a linguagem no tratamento psicanalítico é sempre em associação livre - pois é o psiquismo regido por uma associatividade que lhe constitutiva -, o modo de tratamento está sobreposto a coisa da qual trata. Como nos aponta Delouya (2003):

O dispositivo analítico procede de uma estratégia complexa: limita a informação preceptiva, suprime a visibilidade do objeto e restringe ao mínimo as 
possibilidades de ato; aumenta, assim, a emergência de representações de desejo, dando-lhes um campo de exercício muito mais extenso ou obriga as representações de objeto a se transformarem em palavras, em signos linguísticos organizados em discurso desencadeado pela associação livre. (Delouya, 2003, p.51)

Se para o autor "a função do enquadre é, precisamente, tornar acessível à escuta a função mediadora da fala na retórica do inconsciente.” (Delouya, 2003, p.38), podemos pensar que o vetor que rege o enquadre é dado, pois, pela atenção à associação livre no contexto do tratamento. De modo que tudo no enquadre se direciona, em maior ou menor grau, a favor de sua continuidade. Para Green (2008), mais que as condições materiais variáveis que regulam as relações entre analisando e analista - pagamento das sessões a que falta, férias, duração das sessões, forma de pagamento, etc. - é em sua "matriz ativa" (p.54), constituída pela associação livre do paciente/escuta flutuante e neutralidade do analista, que se localiza o coração da ação analítica, seu núcleo duro. Segundo Green (2008) é a regra fundamental da associação livre que melhor define o enquadre, na medida em que ela não é um ponto de negociação entre o par analítico: "Ela será aceita pelo paciente, mesmo quando a prática lhe revelar que lhe é impossível de respeitar” (p.54).

A associação livre não é um ponto de negociação entre analista e analisando justamente por fundar - no duplo sentido do termo, de instituir e de ser este seu fundamento - o tratamento do tipo psicanalítico. Para Celes (2005a, 2005b), Psicanálise é, em seu sentido originário e fundamental instituído por Freud, o nome dado a um trabalho específico de tratamento, fundamentado na associação livre do analisando e na escuta flutuante do analista. É ato, fazer singular, trabalho que trata o sujeito ao se propor 
a "fazer falar" (vencer resistência) e "fazer ouvir" apropriadamente (interpretação e construção).

De sua leitura dos textos técnicos de Freud, Figueiredo (2000) nos conta que todas as "recomendações negativas" contidas nos artigos, todos os excessos e abusos que o analista deveria evitar, apontam para a abertura de um tipo especial de "presença côncava, em oco" (p.20) do analista. Uma presença que comporta uma certa ausência convidativa, um convite que constitui uma disponibilidade e confiabilidade para o analisando, quando o analista faz "uma reserva de si para o outro" (p.21). Nas palavras do autor, "a proposta freudiana é a de que se crie e se ofereça um espaço, um tempo e um suporte (o que inclui um limite) para as 'emergências psíquicas na forma de associações livres, recordações e repetições" (p.21).

De tal postura exigida do analista ao se fiar nos textos freudianos, Figueiredo (2000) afirma ser inevitável desconsiderar que ela institui uma certa postura ética da psicanálise. Ética que não se resume a uma catalogação de regras e proibições que devem modelar o fazer do analista e serem seguidas cegamente, ou de uma moral (certo e errado), mas como a posição e o lugar que o analista ocupa no tratamento, "uma postura fundamental, como modo de escutar e falar ao e do outro em sua alteridade" (p.7).

Pensamos que nessa postura fundamental ética do analista no tratamento, a associação livre ocupa um lugar central, por instituir, para Freud, uma ética da verdade que abarca analista e analisando.

O tratamento psicanalítico se baseia na veracidade. Aí reside boa parte de seu efeito educativo e do seu valor ético. É perigoso abandonar esse fundamento. Quem se habituou à técnica psicanalítica já não é capaz de recorrer a mentiras e 
logros ... Como exigimos do paciente a mais estrita veracidade, colocaremos em jogo toda a nossa autoridade, se por ele formos flagrados nos afastando da verdade.” (Freud, 1915/2010, p. 218)

Rieff (1969/1979) nos diz que Freud se prontificou a ouvir essa fala que ousa ser honesta, "no lugar da discrição Freud prescreve a fala - a fala inteira, implacável” (p.318). Para Rieff (1969/1979), a psicanálise não tem como objetivo apenas o conhecer sobre o inconsciente, mas o poder dizer dele. É condição do tratamento psicanalítico em associação livre que o sujeito fale, seja honesto com ele mesmo, sem reservas, sem exceções:

Encontramos, primeiramente a ética da honestidade no aspecto freudiano característico - como uma regra meramente terapêutica. Ele nos diz que, verdadeiramente, no começo da terapia, o paciente deve prometer 'absoluta honestidade'. Nem mesmo os nomes podem ser excluídos da comunicação. A honestidade, aprendemos, é a regra fundamental da técnica psicanalítica. (Rieff, 1969/1979, p. 314).

Na ética da honestidade implícita à associação livre, encontramos sua terapêutica fundamental. Não há caminho mais fácil ou mais curto, apontou Freud em diversos momentos. Em verdade, em psicanálise, não há outro caminho. Como nos lembra Mezan (1995), foi da sugestão e da catarse que Freud separou a psicanálise no momento em que abandonou a hipnose e a diretividade em favor da livre-associação: "Frente a esses dois métodos, a psicanálise se situa no extremo oposto: recusando-se a 'introduzir' o que quer 
que seja, ela abandona a direção do tratamento ao paciente, submetido apenas à regra fundamental" (p.25).

Existe, nessa postura, uma ética que relega ao sujeito um papel significativo em seu tratamento, ou seja, na construção de sua cura, que se aproxima de uma independência em relação ao analista: “A isso damos o nome de dissolução da transferência ... se tornar capaz de prosseguir o processo psicanalítico sem a presença de um analista diferente de si, do qual se esperaria, juntamente, que nos diga quem somos" (Mezan, 1995, p. 41). Essa recusa ética do analista está no cerne do princípio da técnica livre associativa tornada regra fundamental no tratamento, "o que distancia o paciente do desejo de permanecer dentro do oráculo materno ou subordinado às verdades interpretativas do analista-pai é a lógica das associações livres do analisando" (Bollas, 2005, p.77).

Em associação livre o método psicanalítico encontra não apenas seu enquadre definidor, mas é através dela que institui sua dimensão ética, que a singulariza diante das outras formas de tratamento. A verdade em psicanálise reside sempre no discurso do sujeito, ou melhor, nas potencialidades de sua associatividade fundamental. Como se o fazer do analista no tratamento psicanalítico, decantado ao extremo, pudesse ser condensado na atitude fundamental de Sancho Pança ao escutar atentamente Don Quixote: Ouves, meu senhor, o que me dizes? (Mannoni, 1992, p. 83).

\subsection{Construções: a elaboração da regra enquanto fundamento}

"Diga-lhe o que vier à mente. Com esse convite o analista define seu método que Freud chamou de associação livre. Apenas uma regra, e não exatamente um contrato." (Viera, 2008, p. 135). Como apontou Viera (2008), os participantes do jogo analítico não 
precisam entrar em consenso acerca de muita coisa, mas ao analisando cabe topar "sair falando, durante algum tempo, a fundo perdido" (p.135). Para o autor, a proposta freudiana não é de uma fala livre, mas de libertar a fala e, assim, poder obter uma novidade no dizer. "Em vez de livre, cega. Numa análise, fala-se às cegas" (Viera, 2008, p.135). A definição do autor sugere que o convite à associação livre se aproxima de um modo de estar na sessão psicanalítica: às cegas e entregue a própria fala.

A psicanálise repousa sobre o exercício da palavra, nos disse Green (2008), seu exercício em psicanálise é "palavra escondida para destinatário oculto" (p.251). Desse modo, o autor aponta que a função ordinária da comunicação não é a mola mestra do que se pretende em análise, muito menos a de sugerir, como na hipnose. Trata-se de outra coisa. Green (2008), ao pensar as relações entre a psicanálise e a linguagem, coloca que:

As exigências do enquadre dão a essa palavra que deve obedecer à regra fundamental um campo que altera as suas condições ordinárias. Pois a associação livre é correlata da regressão tópica, que aproxima a comunicação verbal do estado mental da rêverie, senão do sonho.... A palavra analítica realizou uma verdadeira conversão de tudo aquilo que ela expressa pela linguagem (representação de coisa, afetos, estados próprios do corpo, manifestações compulsivas, tentações de passar à ação e até o próprio desejo). (Green, 2008, p.251)

Assim, a dimensão do enquadre psicanalítico, regulado em sua essência pela regra fundamental, proporciona ao sujeito um espaço de uso singular das palavras e da linguagem, que Green aproxima da liberdade dos sonhos ou devaneios. O tipo específico de conversa proporcionada em uma análise opera uma expansão das possibilidades de 
expressão presentes na linguagem. Green (2001) aprofunda a especificidade desta conversa quando aponta existir, em qualquer discurso associativo em uma sessão psicanalítica, núcleos de reverberação retroativa e anunciação antecipatória:

A demanda de associação livre tem uma dupla consequência. Se, por um lado, ela leva à renúncia da imposição que assegura o encadeamento de ideias, a coerência lógica requerida pelo pensamento secundário, e à liberação, assim, da circulação das divagações temáticas ... este modo de discursividade, ao mesmo tempo frouxa e cindida, facilita, em compensação, pelo afrouxamento das relações internas à comunicação, uma atividade que intensifica modos de irradiação à distância entre partes do discurso, como a poesia e a escrita artística buscam, deliberadamente, mas de maneira controlada. O que nos indica que esta irradiação, que suscita efeitos à distância, parece ser uma capacidade da mente humana acionada, quando ao que o discurso visa não pode ser enunciado, sem fazer com que aquele que se exprime corra um risco. (Green, 2001, p.43)

Green (2001) figura o psiquismo como uma teia extensa e esburacada, do qual a fala, a um só tempo, mostra e esconde muito mais do que se propõe. O recurso à associação livre em análise não apenas privilegia perceber as capacidades semânticas escondidas nos elos entre as palavras, nas reverberações retroativas e antecipatórias de todo discurso submetido à regra fundamental do tratamento, mas os instiga, sempre na contramão de qualquer tendência diretiva. Em outras palavras, o recurso à associaçãolivre busca escutar, a partir da associatividade própria do psiquismo, a associatividade 
que é sua própria essência, favorecendo, desse modo, a possibilidade de dizer o que não pode ser de outra forma dito pelo sujeito.

Roussillon (2012) se alinha à perspectiva de Green quando entende ser própria do psiquismo sua natureza associativa-processual: "enunciar uma regra fundamental, se esta tem então um sentido, é porque ela repousa sobre uma concepção do funcionamento associativo da psique" (p.9). Para o autor, existe uma íntima relação entre a associatividade proposta pela regra fundamental e o que chama de um aumento da capacidade de reflexividade do sujeito, que é descrita como uma melhor forma de se entender, de se ver, e se sentir: "Eu faria tranquilamente a hipótese que uma propriedade emergente de uma associatividade suficientemente implantada seria, com precisão, a reflexividade, e este é o horizonte da 'generatividade associativa' " (p.14). Desse modo, o alcance da consciência de si (reflexividade) é, enquanto horizonte da "generatividade associativa", responsável pela terapêutica do tratamento psicanalítico: “o método da associação livre, liberado, 'trata', ele reinicia a livre circulação dos fluxos associativos" (Roussillon, 2012 p.10).

Portanto, o que "trata" o sujeito em psicanálise é justamente esse modo específico de se percorrer o psiquismo - em associação livre; psiquismo que é, ele mesmo, fundamentalmente associativo. A fala associativa cura ao re-tornar as cadeias associativas e percorrê-las, proporcionando outras ligações, em uma temporalidade singular: a do só-depois. "O método analítico se apoia na capacidade mental de produzir uma sequência associativa e, posteriormente, em discernir sua lógica inconsciente" (Donnet, 2001, p. 227). Configura-se, portanto, em um processo em dois tempos, em que a segunda parte é condicionada pela primeira. Mesmo diante de qualquer impasse transferencial-contratranferencial, o método propõe ao analista que volte ao seu início e 
fundamento original: instaure uma situação analítica - reanálise do analista - ou recorra a uma escuta secundária - supervisão (Donnet, 2001).

De um modo ou de outro, o que se pede ao analista é um retorno ao que Donnet (2001) chamou de desafio original da psicanalise: "falar associando para dar oportunidade ao après-coup interpretativo" (p. 230). Portanto, nesse desafio original reside o cerne da prática psicanalítica, não somente circunscrito à perspectiva terapêutica, mas ampliado para o próprio processo psicanalítico, compreendido aqui em seu sentido fundamental e originário (Celes, 2005a/2005b).

Freud (1923/2011), já sob a égide de sua segunda tópica, escreve dois verbetes para um dicionário de sexologia organizado por Max Marcuse. No primeiro deles, define:

Psicanálise é o nome: 1) de um procedimento para a investigação de processos psíquicos que de outro modo são dificilmente acessíveis; 2) de um método de tratamento de distúrbios neuróticos, baseado nessa investigação; 3) de uma série de conhecimentos psicológicos adquiridos dessa forma, que gradualmente passam a constituir uma nova disciplina científica. (Freud, 1923/2011, p. 274)

Na definição da Psicanálise apresentada nesse momento, Freud distingue, entrelaçando, procedimento, método e conhecimento. Psicanálise é, a um só tempo, um procedimento - portanto um fazer - para a investigação de processos psíquicos de outra forma quase inacessíveis, um método para o tratamento das desordens neuróticas que se funda nessa investigação e o conjunto dos conhecimentos adquiridos por meio dessa prática - a metapsicologia. Nesta tripla articulação feita por Freud entre investigação, técnica e conhecimento, localizamos o lugar onde o processo instituído pela associação 
livre se encontra com o método psicanalítico em seu sentido mais amplo. A técnica da associação livre é utilizável para uma investigação e, como consequência e ao mesmo tempo, se desdobra, como um método de tratamento que transforma o sujeito e produz conhecimento. Donnet (2001) afirma que:

o método inscreve o processo tornado regra fundamental na situação enquadrada. Resulta daí um processo de investigação transformadora. É por isso que o método é utilizável para um tratamento: a cura psicanalítica consiste dos efeitos indiretos adicionais, das transformações psíquicas inerentes ao processo. Apesar da complexidade introduzida, encontramos o postulado fundador de uma verdade que cura. (Donnet, 2001, p. 231)

A leitura feita por Donnet da definição freudiana de 1923 sugere que a regra fundamental, em termos históricos, encontraria seu primeiro uso na psicanálise como processo - puro - de investigação e conhecimento dos processos psíquicos, tendo como efeito "indireto e adicional" um método de tratamento, tornando-se, assim, um "processo de investigação transformadora". Há, nessa perspectiva do autor, a ideia de um deslizamento do processo de investigação para uma terapêutica, que pressupõe algum tipo de derivação do segundo pelo primeiro.

A ideia de deslizamento conduz a uma separação que nos parece excessivamente nítida dos campos da investigação e da terapêutica, que, como chamamos a atenção nos capítulos anteriores, não parecem estar presentes no entendimento freudiano. Investigar, descobrir e curar se conjugaram constantemente na técnica livre-associativa tal como ela 
foi assumida por Freud desde seus primórdios. É justamente na articulação destas três dimensões que Freud encontra sua definição do que era a Psicanálise em 1923.

O entendimento aqui proposto da psicanálise freudiana se aproxima do pensado por Delouya (2003), quando este afirma que, após vinte e quatro séculos de filosofia, o que Freud mudou foi a possibilidade de conceber um aparelho psíquico de forma a poder colocar em ação um método próprio que proporcionasse cura e conhecimento. Ou seja, operações e procedimentos que fazem curar, e que, ao mesmo tempo, modificam o saber do analista e da própria psicanálise:

A peculiaridade do espaço analítico é proporcionar, mediante a operação do método, o enquadre da cura e do conhecimento. Esses processos, de curar e de vir a conhecer, se fundem um ao outro, ocorrem concomitantemente; são por vezes indistinguíveis, e podemos dizer que, nesse caso os verbos são sinônimos. Isso é verdadeiro não só para o analista que resguarda o espaço e faz operar o método, mas ainda no próprio sujeito que se submete à análise. (Delouya, 2003, p. 13)

Delouya (2003) complementa que o enquadre analítico freudiano reedita a situação original de instauração do psiquismo, no qual a linguagem trabalha para a constituição do sujeito, "a mesma relação de princípio, entre instauração do psiquismo e da linguagem, reitera-se, então, não relação entre a fala e o enquadre da situação analítica" (p.51). Tal entendimento, a nosso ver, pode ser encontrado, sob outros termos, na elaboração final que Freud faz da técnica psicanalítica em Construções na análise de 1937. 
Se em Recordar, repetir e elaborar, como apontamos, os limites da lembrança já haviam sido questionados por Freud com a noção de compulsão à repetição, é em Construções na análise que a recuperação da recordação per se vai ser progressivamente abandonada por Freud como meta da análise. Com o texto de 1937, "a lembrança perde quase tudo de sua importância, sendo substituída pela emergência da pulsão; e, no ouvir do analista, a intenção de fazer surgir a lembrança fica substituída pela escuta da pulsão emergente" (Celes, 2008, para. 11).

Nesse momento, nos diz Freud (1937/2017), o que “queremos é uma imagem dos anos de vida esquecidos do paciente, imagem que seja confiável e consistente em todas as partes essenciais" (p.366). Para tanto, o analista, que não vivenciou nem recalcou nada, não pode lembrar pelo paciente, "ele terá que inferir o esquecido a partir dos sinais por ele deixados, ou, mais corretamente, ele terá de construir o esquecido" (p.367). O que Freud postula é que, em algum momento da análise, geralmente depois de muito ouvir seu analisando, o analista precisará construir a partir de fragmentos, dos restos de seu discurso, uma narração que recupere as partes ausentes da pré-história do sujeito. Ao analista cabe "um trabalho de construção, ou, se preferirmos, de reconstrução" (p.367).

Em Construções na análise, "o infantil, parcial, fragmentado, pré-histórico, anterior à aquisição da linguagem, ainda não apreendido pela linguagem verbal, que lhe traria possibilidades associativas plenas, se expressa como rastro" (Celes, 2013, p.213), que cabe ao ouvir do analista recolher na fala do analisando para, a partir dele, sugerir ao analisando, reconstruir, não uma lembrança fechada e completa, mas fragmentos de síntese. Freud (1937/2017) observa não residirem no "sim" ou no "não" do analisando a validade ou pertinência de uma construção, mas nos efeitos que ela exerce sobre a continuidade da análise: se, a partir de uma construção o analisando dá prosseguimento à 
associação livre, se em decorrência dela surge uma "confirmação indireta por meio das associações que combinam com o conteúdo das construções" (p. 374).

É à continuidade da fala associativa, à continuidade do processo analítico, que Freud credita a validade e a eficácia de uma boa construção. Como lembrou Celes (2005b): "Se as construções em análise têm um caráter de síntese, elas o têm parcialmente e devem ser de tal ordem que permitam a análise, isto é, uma permanente produção de material, o reinício da associação livre.” (p. 42). Indaga-se, portanto, em uma construção acerca de sua potencialidade de produzir associações no analisando, de gerar mais associatividade, “constrói-se em psicanálise para haver novas construções, para se dar seguimento ao trabalho de psicanálise." (Celes, 2005b, p. 42). Para Roussillon (2012), o que está em jogo na construção freudiana é a "generatividade associativa" que o analista faz surgir no tratamento, as associações que sua intervenção torna possíveis: "Ainda aqui, é à associatividade que o trabalho psicanalítico se refere, é nela que ele encontra o seu fundamento e sua razão de ser, que ele é avaliado.” (p. 14).

Se, como propõe Celes (2013), o analista, ao fazer uma construção, de algum modo se antecipa às associações do analisando "precisamente porque esta não lhe está ao alcance, por suposto, não lhe é estruturalmente disponível” (pp.214-215), essa antecipação não o situa fora do campo da associatividade. É ainda sobre a égide da associação livre que Freud (1937/2017) se movimenta quando alarga a possibilidade do que pode fazer o analista no tratamento, haja vista que este não constrói a partir da metapsicologia, ainda que a tenha em mente, mas a partir dos 'rastros de infantil' que escuta em atenção flutuante, estes mesmos associativamente determinados para o analisando. A própria necessidade de o analista construir apareceria, para Freud (1937/2017), apenas quando o discurso em associação livre do analisando se interrompeu 
por uma lacuna significativa, diferente de uma simples resistência que poderia ser vencida pela ação da interpretação. Portanto, no modelo proposto em Construções na análise, a associação livre como referência está presente antes (no rastro infantil, na lacuna), durante (na escuta flutuante, na síntese fragmentada construída) e depois (na confirmação indireta, na continuidade da análise), ela continua sua base, ou melhor dizendo: seu fundamento.

O que é apresentado por Freud (1937/2017) como uma liberdade dada ao analista, uma flexibilização no preceito da abstinência, para escutar mesmo o que não é dito pelo analisando e construir, configura-se ao mesmo tempo como uma obrigação para que o tratamento avance, para que se encontrem palavras, para a continuidade da elaboração proporcionada pela fala associativa. Freud (1937/2017) nos diz que:

O caminho que começa com a construção do analista deveria terminar com a recordação do paciente; nem sempre ele vai tão longe. Inúmeras vezes não conseguimos levar o paciente à recordação do recalcado. Em vez disso, se executarmos a análise de forma correta, conseguimos que ele tenha uma convicção segura da verdade da construção, que, do ponto de vista terapêutico, tem o mesmo efeito que uma recordação recuperada. (Freud, 1937/2017, p.376)

O efeito terapêutico descrito aqui por Freud dependerá do acolhimento pelo analisando da construção com "a súbita vinda à tona [auftrieb] do recalcado, ativada pela comunicação da construção" (Freud, 1937/2017, p. 377). Como apontou Celes (2008), o analista ao deter sua escuta nos rastros de infantil deixados pelo discurso do analisando e com eles construir, "faz acontecer a associação livre. Por fim, e no limite, a lembrança é 
substituída por uma atitude anímica, que Freud nomeia de convicção" (para. 11). Convicção esta que se estabelece para o analisando como o resultado da elaboração inconsciente do movimento pulsional que o fragmento de síntese construído pelo analista, a um só tempo, despertou e apreendeu. (Celes, 2013, p.214). Se no trecho subsequente Freud (1937/2017) aproxima este efeito à força de uma alucinação, o que faz é "permitir uma equivalência entre a força de convicção do delírio e a força de convicção de uma construção psicanalítica" (Figueiredo, 1996, p.88).

Figueiredo (1996) sugere que, ao fazer uma construção, o analista delira no lugar do analisando, ele "produz o delírio que o paciente (neurótico) não consegue engendrar" (p.89); o autor localiza, assim, a construção freudiana completamente de fora do império do princípio da razão. O que se propõe na atividade de construção feita pelo analista é que ela "mobilize as pulsões, toque o inconsciente e faça emergir, ainda que de forma irreconhecível, uma verdade histórico-vivencial: construções não são 'proposições verdadeiras', são retorno de vivências soterradas, paralisadas, fragmentadas com os quais é possível se fazer uma experiência" (Figueiredo, 1996, p.89).

Para Figueiredo (1996), o que Freud apresenta ao fazer técnico do analista em 1937 se distancia de uma retórica que engendraria convencimento, ao contrário, a construção, ao produzir uma emergência pulsional no sujeito, daria "figurabilidade àquilo que sempre 'existiu' apenas como fragmento desligado, como possibilidade abortada de ligação: uma cena traumática, uma intensidade afetiva, um acontecimento inconcluso.” (p. 89). Ou seja, uma boa construção seria capaz de promover a associatividade, a efetiva ligação de um fragmento desligado, mas atuante no psiquismo do analisando; a convicção advinda dessa construção, seu efeito terapêutico, se fundaria no verdadeiro ingresso desse fragmento na cadeia associativa do sujeito. Parafraseando Figueiredo (1996), poderíamos 
dizer que o analista ao construir, ao alucinar pelo analisando, associa em seu lugar, produz a fala associativa que ele não tem palavras para dizer.

O que pensamos, portanto, encontrar em Freud com o artigo Construções na Análise, quiçá sua última contribuição à técnica psicanalítica, é um alargamento do alcance e dos efeitos que a associação livre tem para o trabalho da análise, um refinamento da técnica nomeada outrora como sua única regra, sua elaboração final enquanto fundamento do tratamento psicanalítico. Se do recurso à regra fundamental, no início dos escritos freudianos, se esperava um "tudo trazer ou lembrar", a construção se apresenta como constatação de que a fala do analisando não consegue tudo dizer sozinha. Freud propõe como desafio ao analista a escuta de uma "associatividade não verbal" (Roussillon, 2012, p.20) como única saída para a compulsão à repetição; requer do analista um "além de interpretação", contido na construção, para que o tratamento prossiga.

Assim, a associação livre vai ficando à margem enquanto expectativa do analista de que ela compareça apenas na fala do analisando, mas a associatividade se firma em definitivo como o fundamento do trabalho de tratamento. Em outras palavras, a associação livre se torna marginal, vai desaparecendo como regra rígida, se dissolve no tratamento, enquanto se entranha definitivamente como fundamento no método e na técnica da psicanalise. 


\section{Considerações Finais}

Não fosse isso e era menos.

Não fosse tanto e era quase.

Paulo Leminski

Ao fazer psicanálise, o meu objetivo é manter-me vivo, manter-me bem, manter-me acordado. Meu objetivo é ser eu mesmo e a me comportar como tal.

Winnicott (1962)

Dois completos desconhecidos se encontram com regularidade em um determinado local, em geral por alguns anos. Um se deita; outro acomoda-se sentado, distante do olhar do primeiro. Um diz o que lhe vem à cabeça; o outro, em silêncio, o escuta. Trocam entre si apenas palavras. E ... algo acontece. Tal sintética e descompromissada descrição de uma experiência psicanalítica poderia ser feita por um observador externo à situação, este, por definição, inexistente em qualquer análise. Após pouco mais de uma década de vivência psicanalítica, enquanto analista e analisando, penso que o descrito acima nunca deixou de me intrigar e causar assombro. Por que isso, de algum modo, funciona? Por que assim? Desconfio ter sido esse o questionamento inicial que, se desdobrando e associando a outros tantos trazidos por minha experiência no consultório, me levou à pesquisa e a escrita desta dissertação de Mestrado.

Pensando que era justamente no recurso à livre-associação, na regra fundamental da associação livre, que a psicanálise se singularizava de outras práticas de tratamento pela palavra (Mezan, 1995), e supondo que, durante todo o complexo e intricado processo 
de construção teórica da psicanálise efetuada por Freud em sua extensa obra, a associação livre não parecia ter perdido sua relevância na prática psicanalítica, circunscrevemos o objeto de investigação desse trabalho. Foi efetuado um recorte, que teve a obra escrita de Freud como objeto de análise principal, mas que buscou se valer também de outros autores que pensaram e pensam a psicanálise freudiana e pós-freudiana. Realizamos um percurso que tentou acompanhar de que maneira a associação livre surgiu e foi se estabelecendo para Freud como marca distintiva de seu método de tratamento e investigação. Por quais caminhos a técnica do tratamento, ou mais especificamente, o fundamento do método com o qual o analista trabalha concretamente no cotidiano do consultório, foi se balizando por esse modo específico de fala e escuta associativas.

Chamou nossa atenção, inicialmente, Freud ter proposto, antes de sua teoria do aparelho psíquico, uma concepção de um aparelho de linguagem (Sprachapparat) dinâmico, cuja base de funcionamento residia no modo associativo das representações contidas na linguagem. Freud demonstrava, naquele momento, não ter distante de suas reflexões a importância atribuída à linguagem no funcionamento e na estruturação psíquica, bem como as complexas relações que se estabeleciam entre linguagem e psiquismo nos tratamentos. Diante dos problemas que encontrou nos adoecimentos afásicos, o autor postulou a ideia de um aparelho de fala que seria, em última instância e originalmente, um aparelho associativo; ao mesmo tempo em que já vislumbrava os limites que o método hipnótico trazia para os tratamentos anímicos que tentava empreender com seus pacientes. O posterior nascimento da psicanálise, como um método de tratamento específico e singular fundado na associatividade, nos parece tributário da investigação e das experiências freudianas desse período. 
Se os estudos teóricos anteriores, como vimos em Tratamento Psíquico (tratamento anímico) e Sobre a Concepção das Afasias, podem ser lidos como um ensaio das reflexões de Freud sobre o funcionamento mental, seu Estudos sobre a Histeria foi o grande laboratório para seu método de tratamento em gestação, no qual a característica eminentemente associativa do psiquismo se desnudou mais claramente a partir das experiências de tratamento. $\mathrm{O}$ que nos parece comparecer de forma evidente nos relatos clínicos desse estudo é a busca de Freud por uma técnica que fizesse suas pacientes falarem, ou melhor dizendo, lembrarem-se pela fala. A técnica freudiana foi passando por ajustes, reformulações e adaptações, mas foi no tratamento da histeria que o método floresceu e a técnica da livre-associação foi aos poucos se impondo para Freud em suas potencialidades terapêuticas (kur); a um só tempo, sendo descoberta e inventada por Freud a partir suas experiências de tratamento com as histéricas.

Caberia aqui, talvez, um paralelo com o paradoxo do achado/criado existente na concepção do objeto transicional para Winnicott (1955/1982), segundo a qual, o que tem função de objeto transicional para o sujeito precisa ser "tanto criado como encontrado" (p.191), sob pena de padecer em suas potencialidades de estruturação subjetiva. Parecenos que o exposto em Estudos sobre a Histeria denota a mesma dinâmica paradoxal e cíclica, através da qual a associação livre foi sendo, a um só tempo, apresentada e (re)elaborada por Freud em seu método de trabalho, até alcançar o status de regra fundamental do tratamento psicanalítico.

O abandono da hipnose inaugurou a história da psicanálise propriamente dita e a progressiva adoção da técnica livre-associativa no contexto do tratamento teve a consequência de levar Freud a se ocupar dos processos oníricos. O autor se apropriou da associação livre como técnica e a adotou efetivamente como ferramenta essencial de seu 
método de interpretação dos sonhos. Foi por meio da técnica de interpretação dos sonhos, ou seja, da técnica livre-associativa, que Freud alcançou e estruturou sua teoria do aparelho psíquico. Construiu, assim, sua metapsicologia e definiu um método próprio à psicanálise, diferente do método catártico de Breuer; alçando, em definitivo, a associação livre à condição de regra fundamental prática de seu método de tratamento.

Nas experiências concretas de tratamento, a regra passou por um processo de elaboração no qual o discurso em associação livre do paciente ganhou um papel cada vez mais central e suas possibilidades terapêuticas se evidenciaram para Freud. A regra fundamental, enquanto ocorrência [Einfalle], instituiu nos tratamentos uma situação de fala e escuta associativas singulares ao método freudiano e que continham, em si mesmas, um potencial elaborativo para o psiquismo. Ao mesmo tempo, apresentou-se para Freud, às claras, $\mathrm{o}$ fenômeno da transferência com toda sua problemática para a técnica psicanalítica. A associação livre, enquanto regra, encontrou então seu primeiro grande entrave no tratamento: ela faria o sujeito continuar associando, não mais por meio de seu discurso, mas em seus atos em relação ao analista.

Freud não apenas manteve a livre-associação como regra fundamental do tratamento, mas a tomou como o vetor principal utilizado para definir e estabelecer o enquadre analítico que apresentou em seus textos técnicos. De modo que, tudo o que na prática do método psicanalítico deveria fazer ou deixar de fazer o analista - escuta em atenção flutuante, abstinência, manejo transferencial - funcionava em favor de promover ou favorecer a continuidade do trabalho livre-associativo necessário ao tratamento. A fala em associação livre, quando efetivamente associativa, continha potencial elaborativo para Freud. A esse trabalho, empreendido em conjunto por analista e analisando, sugerimos, 
se referia à noção freudiana de perlaboração de 1914, pensada como o trabalho elaborativo da associação livre no tratamento (Resende, 2001).

Do enquadre psicanalítico proposto por Freud em seus escritos técnicos, depreendemos uma dimensão ética postulada no tratamento (Figueiredo, 2000), na qual a associação livre ocupa um lugar central, por instituir uma ética da honestidade (Rieff, 1969/1979) que relega ao analisando um papel significativo na construção de sua cura e, progressivamente, favorece o trabalho de dissolução da transferência e de independência do sujeito em relação ao analista. Para concluir nosso percurso, abordamos como a introdução do conceito de construção na obra freudiana se configurou como uma liberdade/necessidade oferecida ao analista de ouvir a associatividade para além do que comparece no discurso pela via da regra fundamental, produzindo-se através dela a fala associativa quando inexistem no analisando palavras para a dizer. Ao promover a associatividade, a efetiva ligação de um fragmento psíquico desligado, uma construção produz convicção e dá prosseguimento à análise, ao mesmo tempo em que trata o sujeito. Encontramos, na última contribuição freudiana à técnica psicanalítica, um alargamento das potencialidades que a associação livre tem para o trabalho da análise, sua elaboração final enquanto fundamento do tratamento psicanalítico.

Cogitamos, por fim e para concluir este trabalho, que o conceito freudiano de construção nos proporciona novas aberturas para pensar o funcionamento do trabalho da associação livre, por ele ampliado, nos tratamentos de estruturações psíquicas diferentes daquelas do modelo neurótico. Como apontou Celes (2013), são justamente nas questões colocadas pelas falhas narcísico-identitárias, tão frequentes nas discussões teóricas da psicanálise atual dos casos limites, quando o analista se depara com partes insondáveis e inacabadas do psiquismo, que ele precisará construir algo para que a análise aconteça. 
Vários foram os autores que escreveram sobre tais situações e propuseram, para atender às novas demandas de análise, flexibilizações no que se convencionou chamar de psicanálise padrão. Alguns, tais como: Green (2008), com a psicoterapia psicanalítica baseada no enquadre internalizado do analista, Roussillon (2005, 2012), com a conversação psicanalítica no face a face e na necessária atenção do analista ao registro mimo-gesto-tônico-postural, e Ogden (1996), ao apresentar uma crítica ao apego à regra fundamental no contexto clínico. Todos eles aparentam defender uma restrição do espaço que a associação livre teria na técnica de um enquadre psicanalítico modificado, reservando-a para os casos ou para os momentos em que um tratamento padrão possa ter lugar.

O que esses autores parecem colocar em questão, a nosso ver, é a associação livre tomada em sua dimensão de regra fixa do fazer analítico, que, como nosso trabalho buscou demonstrar, não é o essencial do que nos legou Freud quando a situou como fundamento técnico do tratamento. Uma discussão mais aprofundada seria exigida para desenvolvermos adequadamente essa colocação, o que o escopo e o espaço deste trabalho não nos permitem. De todo modo, alinhamos nosso entendimento ao que foi apontado por Celes (2008):

Ainda que se tracem diversos entendimentos sobre regra fundamental, a base do "discurso associativo" como sendo o que conduz ao inconsciente é inalienável da psicanálise, essa base a sustenta e a justifica como prática de tratamento. A descaracterização da associação livre e, portanto, da intenção fundamental da psicanálise, implica a descaracterização da própria psicanálise. (Celes, 2008, para. 14) 
Nesse sentido, se Freud, em seu último texto técnico, aparentemente se afasta da associação livre como norteadora do fazer analítico, ele o faz apenas de seu entendimento enquanto regra "maníaca" a ser cegamente cumprida, seja pelo analisando ou pelo analista. Nossa leitura é a de que, do começo ao final da obra freudiana, é sua assunção como fundamento absoluto do tratamento psicanalítico o que encontramos. Em Freud, ousaríamos (d)escrever: psicanálise é em associação livre, sempre.

Freud não abre mão de postular que a linguagem no tratamento psicanalítico é em associação livre, pois é o psiquismo, ele mesmo, regido por uma associatividade que lhe é constitutiva e potencialmente terapêutica - o modo do tratamento espelha-se na coisa da qual trata. Exige trabalho, trabalho de análise. Não há caminho mais fácil ou mais curto, apontou Freud em diversos momentos. Em verdade, em psicanálise, não há outro caminho afora o da associatividade. O recurso à associação livre busca escutar a partir da associatividade que é a própria essência do psiquismo. Ainda nos momentos em que essa não é possível, ela segue como horizonte do tratamento levado adiante pela prática psicanalítica. Continua seu fundamento primordial.

Ao cabo de todo este percurso, penso não ter encontrado uma resposta definitiva para a questão mais ampla que apontei ser, talvez, sua motivação inicial. Mas percebo que sua demanda gerou o trabalho de associatividade, portanto de elaboração, do qual essa dissertação é o resultado mais tangível, mas não o único. Dou-me por satisfeito. 


\section{Referências Bibliográficas}

André, J. (2015). Vocabulário básico da psicanálise. Trad. Marcia Valéria Martinez de Aguiar. São Paulo: Martins Fontes.

Anzieu, D. (1989). A auto-análise de Freude a descoberta da psicanálise. (F. F. Settineri, Trans.). Porto Alegre: Artes Médicas.

Bollas, C. (2005). Associação Livre. Rio de Janeiro: Relume Dumará.

Breuer, J. \& Freud, S. (1895/1987). Estudos sobre a histeria. Em S. Freud. Edição Standard Brasileira das Obras Psicológicas Completas de Sigmund Freud. v. II. Rio de Janeiro: Imago.

Breuer, J. \& Freud, S. (1895/2016). Estudos sobre a histeria. Em S. Freud, Obras completas. Estudos sobre a histeria (1893-1895). (Paulo Cesar Lima de Souza, Trad., Vol. 2). São Paulo: Companhia das Letras.

Celes, L. A. M. (2005a). Psicanálise é o nome de um trabalho. Psicologia Clínica., 17(2), $157-171$.

Celes, L. A. M. (2005b). Psicanálise é trabalho de fazer falar, e fazer ouvir. $P S Y C H \hat{E}-$ revista de psicanálise. São Paulo, ix (16), p. 25-48.

Celes, L. A. M. (2007). "Dora" contemporânea - e a crise terapêutica da psicanálise. Psic.Clin. Rio de Janeiro, VOL. 19, N.1, p.137-154.

Celes, L. A. M. (2008). Crise terapêutica da psicanálise e presença do analista. Percurso - Revista de Psicanálise. São Paulo, v. XXI, pp. 47-54. (Acessado em 
http://revistapercurso.uol.com.br/index.php?apg=artigo_view\&ida=60\&ori=a utor\&letra=C)

Celes, L. A. M. (2013). Experiências arcaicas e técnica psicanalítica. Em L. C. Figueiredo, B. B. Savietto, O. Souza (orgs). Elasticidade e limites na clínica contemporânea. (pp. 205-222). São Paulo: Escuta.

Chervet, E. (2016). Patient, et interprète. Le domaine intermédiaire. Bulletin de la Société Psychanalytique de Paris. Paris, $\mathrm{n}^{\circ}$ 2017-1 (2017), pp. 35-111.

Coelho Junior, N. E. (2004). Ferenczi e a experiência da Einfühlung. Ágora: Estudos em Teoria Psicanalítica, 7(1), 73-85

Delouya, D. (2003). Epistemopatia: o conhecimento na clínica psicanalítica. Coleção clínica psicanalítica. São Paulo: Casa do Psicólogo.

Donnet, J. (2001) A regra fundamental e a situação de análise. Revista Brasileira de Psicanálise. São Paulo, n. 35 (1), pp. 227-242.

Ferenczi, S. (1918/1992). A técnica psicanalítica. Em S. Ferenczi. Obras Completas

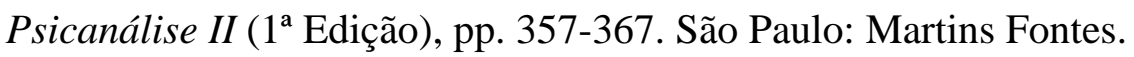

Figueiredo L. C. (1996). Pensar, escutar e ver na clínica psicanalítica. Uma releitura de “construções em análise”. Percurso - Revista de Psicanálise. São Paulo, v. 8, n. 16 , pp. 81-89.

Figueiredo, L. C. (2000). Presença, implicação e reserva. Em L. C. Figueiredo \& N. E. Coelho Junior. Ética e Técnica em Psicanálise (pp. 9-50). São Paulo: Escuta. 
Forrester, J. (1983). A linguagem e as origens da psicanálise. Rio de Janeiro: Imago.

Freud, S. (1890/2017). Tratamento psíquico (tratamento anímico). Em S. Freud. Fundamentos da Clínica Psicanalítica. Coleção Obras Incompletas de Sigmund Freud. (Claudia Dornbusch, Trad.). (pp. 19-46). Belo Horizonte: Autêntica Editora.

Freud, S. (1891/2013). Sobre a concepção das afasias: um estudo crítico. Coleção Obras Incompletas de Sigmund Freud. (Emiliano de Brito Rossi, Trad.). Belo Horizonte: Autêntica Editora.

Freud, S. (1893/1987). Algumas considerações para o estudo comparativo das paralisias motoras orgânicas e histéricas. Em S. Freud. Edição Standard Brasileira das Obras Psicológicas Completas de Sigmund Freud, v. I (pp. 177-198). Rio de Janeiro: Imago.

Freud, S. (1895/1987). Projeto para uma Psicologia Científica. Em S. Freud. Edição Standard Brasileira das Obras Psicológicas Completas de Sigmund Freud, v. I (pp. 315- 410). Rio de Janeiro: Imago.

Freud, S. (1900/1987). A interpretação dos sonhos. Em S. Freud. Edição Standard Brasileira das Obras Psicológicas Completas de Sigmund Freud, v. IV e V. Rio de Janeiro: Imago.

Freud, S. (1900/2017). Carta a Fliess 242[133](16 de abril de 1900). Em S. Freud. Fundamentos da Clínica Psicanalítica. Coleção Obras Incompletas de Sigmund Freud. (Claudia Dornbusch, Trad.). (pp. 47-48). Belo Horizonte: Autêntica Editora. 
Freud, S. (1905/2016). Análise fragmentária de uma histeria. Em S. Freud, Obras completas. Três ensaios sobre a teoria da sexualidade, análise fragmentária de uma histeria ("o caso dora") e outros textos (1901-1905). (Paulo Cesar Lima de Souza, Trad., Vol. 6, pp. 173-320). São Paulo: Companhia das Letras.

Freud, S. (1912a/2010). A dinâmica da transferência. Em S. Freud, Obras completas. Observações psicanalíticas sobre um caso de paranoia relatado em autobiografia ("o caso schreber"), artigos sobre técnica e outros textos (19111913). (Paulo Cesar Lima de Souza, Trad., Vol. 10, pp. 133 - 146). São Paulo: Companhia das Letras.

Freud, S. (1912b/2010). Recomendações ao médico que pratica a psicanálise. Em S. Freud, Obras completas. Observações psicanalíticas sobre um caso de paranoia relatado em autobiografia ("o caso schreber"), artigos sobre técnica e outros textos (1911-1913). (Paulo Cesar Lima de Souza, Trad., Vol. 10, pp. 147 - 162). São Paulo: Companhia das Letras.

Freud, S. (1913/2010). O Início do Tratamento. Em S. Freud, Obras completas. Observações psicanalíticas sobre um caso de paranoia relatado em autobiografia ("o caso schreber"), artigos sobre técnica e outros textos (19111913). (Paulo Cesar Lima de Souza, Trad., Vol. 10, pp. 163 - 192). São Paulo: Companhia das Letras.

Freud, S. (1914/2010). Contribuição à história do movimento psicanalítico. Em S. Freud, Obras completas. Totem e tabu, contribuição à história do movimento psicanalítico e outros textos (1912-1914). (Paulo Cesar Lima de Souza, Trad., Vol. 10, pp. 245-327). São Paulo: Companhia das Letras. 
Freud, S. (1914/2017). Lembrar, repetir e perlaborar. Em S. Freud. Fundamentos da Clínica Psicanalítica. Coleção Obras Incompletas de Sigmund Freud. (Claudia Dornbusch, Trad.). (pp. 151-164). Belo Horizonte: Autêntica Editora.

Freud, S. (1915/2010). Observações sobre o amor de transferência. Em S. Freud, Obras completas. Observações psicanalíticas sobre um caso de paranoia relatado em autobiografia ("o caso schreber"), artigos sobre técnica e outros textos (19111913). (Paulo Cesar Lima de Souza, Trad., Vol. 10, pp. 210 - 228). São Paulo: Companhia das Letras.

Freud, S. (1920/2011). Contribuição à pré-história da técnica psicanalítica. Em S. Freud, Obras completas. Psicologia das massas e a análise do eu e outros textos (1920-1923). (Paulo Cesar Lima de Souza, Trad., Vol. 15, pp. 310 - 314). São Paulo: Companhia das Letras.

Freud, S. (1923/2011). Psicanálise e teoria da libido. Em S. Freud, Obras completas. Psicologia das massas e análise do eu e outros textos (1920-1923). (Paulo Cesar Lima de Souza, Trad., Vol. 15, pp. 273-308). São Paulo: Companhia das Letras.

Freud, S. (1937/2017). Construções na análise. Em S. Freud. Fundamentos da Clínica Psicanalítica. Coleção Obras Incompletas de Sigmund Freud. (Claudia Dornbusch, Trad.). (pp. 365-382). Belo Horizonte: Autêntica Editora.

Garcia-Roza, L. A. (1988). Freud e o inconsciente. 4 ed. Rio de Janeiro: Jorge Zahar.

Gay, P. (1988/2004). Freud: uma vida para o nosso tempo. São Paulo: Companhia das Letras. 
Green, A. (1988). Narcisismo de vida. Narcisismo de morte. Trad. C. Berliner. São Paulo: Escuta.

Green, A. (2000). As cadeias de Eros. Actualidade do sexual. Trad. A. P. Morais. Lisboa: Climepsi.

Green, A. (2001). A posição fóbica central. Psicanalise - Revista da Sociedade Brasileira de Psicanalise de Porto Alegre, 3 (1), pp. 35- 70.

Green, A. (2004). O silêncio do psicanalista. Psyché. São Paulo, Ano VIII, número 14, pp. 13-38.

Green, A. (2008). Orientações para uma psicanálise contemporânea. Trad. A. M. R. Rivarola et al. São Paulo/Rio de Janeiro: SBPSP, Depto. de Publicações/Imago.

Iannini, G. \& Tavares, P. H. (2017). Apresentação e notas. Em S. Freud. Fundamentos da Clínica Psicanalítica. Coleção Obras Incompletas de Sigmund Freud. (Claudia Dornbusch, Trad.). (pp. 7-18). Belo Horizonte: Autêntica Editora.

Jorge, M. A. C. (2008). Fundamentos da Psicanálise de Freud a Lacan, vol. 1: as bases conceituais. 5.ed. Rio de Janeiro: Zahar.

Jorge, M. A. C. (2017). Fundamentos da Psicanálise de Freud a Lacan, vol. 3: a prática analítica. Rio de Janeiro: Zahar.

Kehl, M. R. (2002). A virada freudiana. Em M. R. Kehl. Sobre ética e psicanálise. (pp. 107-135). São Paulo: Companhia das Letras.

Lacan, J (1953/1986). O seminário: Livro 1 - os escritos técnicos de Freud. Rio de Janeiro: Jorge Zahar Editor. 
Laplanche, J. \& Pontalis, J.-B. (1967/2004). Vocabulário da Psicanálise. São Paulo: Martins Fontes.

Le Guen. C. (1982/1991). Pratica do método psicanalítico - A dialética freudiana 1. São Paulo: Escuta.

Loyola, V. M. Z. (2005). A metáfora no trabalho clínico: ensaios teórico-clínicos acerca das funções da metáfora no processo analítico. 257 f. Tese (Doutorado). Universidade de Brasília, Instituto de Psicologia, 2005.

Lysy-Stevens, A. (2000). A sessão freudiana. Em Textos Reunidos pela Fundação do Campo Freudiano. A sessão analítica. Dos riscos éticos da clínica. (pp.13-25) Campo freudiano no Brasil. Jorge Zahar. Rio de Janeiro.

Mannoni, O. (1992). O divã de procusto. Em O. Mannoni. Um espanto tão intenso: a vergonha, o riso, a morte. (pp. 81-94). Rio de Janeiro: Campus.

Mannoni, O. (1992). O que é associar livremente?. Em O. Mannoni. Um espanto tão intenso: a vergonha, o riso, a morte. (pp. 75-79). Rio de Janeiro: Campus.

Masson, J. M.(ed.) (1986). A correspondência completa de Sigmund Freud para Wilhelm Fliess - 1887-1904. Rio de Janeiro: Imago.

Mezan, R. (1995). Psicanálise e Psicoterapia. Em R. Mezan. A vingança da esfinge: ensaios de psicanálise. (2a ed.) (pp. 21-42). São Paulo: Brasiliense.

Mezan, R. (1998). Freud: a trama dos conceitos. São Paulo: Perspectiva.

Mezan, R. (2014). O tronco e os ramos. Estudos de História da psicanálise. São Paulo: Companhia das Letras. 
Nosek, L. (2015). O analista e sua circunstância. Jornal de psicanálise. São Paulo, vol.48, n.88, pp. 19-28. ISSN 0103-5835.

Ogden, T. H. (1996). Reconsiderando tres aspectos de la técnica psicoanalítica. Int. J. Psycho-Anal. (1996) 77, 883. (Acessado em http://www.apdeba.org/wpcontent/uploads/Ogden.pdf.)

Resende, T. I. M. (2001). Perlaboracão: Trabalho do tempo e alteridade em psicanálise. 127 f. Dissertação (Mestrado). Universidade de Brasília, Instituto de Psicologia, 2001.

Rieff, P. (1969/1979). A ética da Honestidade. Em P. Rieff. Freud pensamento e humanismo. Trad. Silvana Borin Mirachi. Belo Horizonte: Interlivros.

Rossi, E. B. (2013). Posfácio. Em S. Freud. Sobre a concepção das afasias: um estudo crítico. (pp.151-166). Coleção Obras Incompletas de Sigmund Freud. (Emiliano de Brito Rossi, Trad.). Belo Horizonte: Autêntica Editora.

Roussillon, R. (2005). La conversation psychanalytique: um divan em latance. Revue Française de Psychanalyse, Vol. 69, n. 2, p. 365-381 (Tradução de Eline Batistella. Acessado em https://pt.scribd.com/document/102490521/Aconversacao-psicanalitica-Um-diva-em-latencia-por-R-Roussillon)

Roussillon, R. (2012). As condições da exploração psicanalítica das problemáticas narcísico-identitárias. Alter-Revista de Estudos Psicanalíticos, Brasília, v. 30, n. 1, p. 7-32. 
Tavares, P. H. (2013). Apresentação. Em S. Freud. Sobre a concepção das afasias: um estudo crítico. (pp.7-14). Coleção Obras Incompletas de Sigmund Freud. (Emiliano de Brito Rossi, Trad.). Belo Horizonte: Autêntica Editora.

Vaz, H. L. (1988). Ética e ciência. Em H. L. Vaz. Escritos de Filosofia II: ética e cultura. Coleção filosofia 8. (pp.181-224). São Paulo: Edições Loyola.

Vieira, M. A. (2008). O analista e as cidades. Em M. A. Viera. Restos: uma introdução lacaniana ao objeto da psicanálise. (pp. 135-141). Rio de Janeiro: Contra Capa.

Winnicott, D. W. (1955/1982). Primeiras experiências de independência. Em D. W. Winnicott. A criança e seu mundo. (pp.189-195). Rio de Janeiro: Zahar editores. 